ISSN print 2712-9217 • №2 (7) • июнь • 2021 ISSN online 2712-9225• DOI 10.29188/2542-2413

\title{
РОсСИЙСКИЙ ЖУРНАЛ
}

ТЕЛЕМЕДИЦИНЫ И ЭЛЕКТРОННОГО

ЗАРАВООХРАНЕНИЯ

RUSSIAN JOURNAL OF TELEMEDICINE AND E-HEALTH 


\section{Портативный анализатор мочи «ЭТТА АМП-01» на тест-полосках}

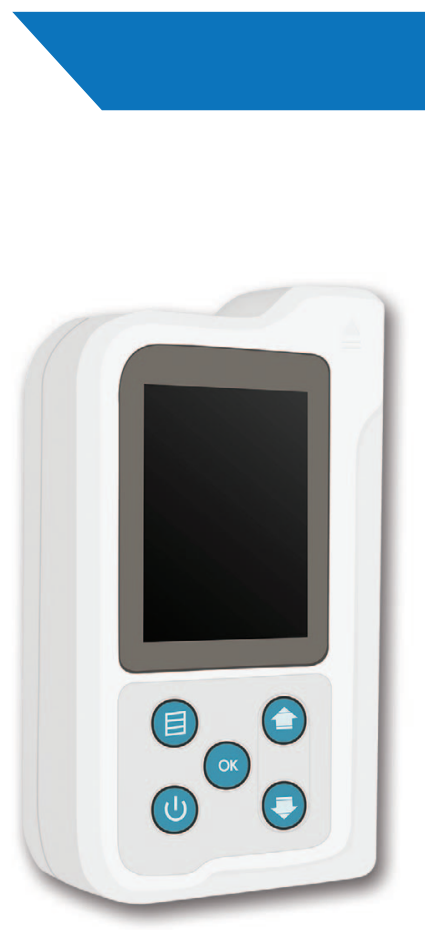

\section{Экспресс-анализ мочи}

$>$ Используется для проведения экспресс-анализа проб мочи

$>$ Построен на современных фотоэлектрических и микропроцессорных технологиях

Bec: 180 r

300 анализов на одном заряде батареи

Ресурс: 5000 исследований

Гарантия 12 месяцев

Беспроводной протокол передачи данных

Простота эксплуатации

Результат за 1 минуту

Бесплатное мобильное приложение

\section{$>$ Условия применения:}

в медицинских учреждениях, для проведения выездных обследований, для частного применения в домашних условиях

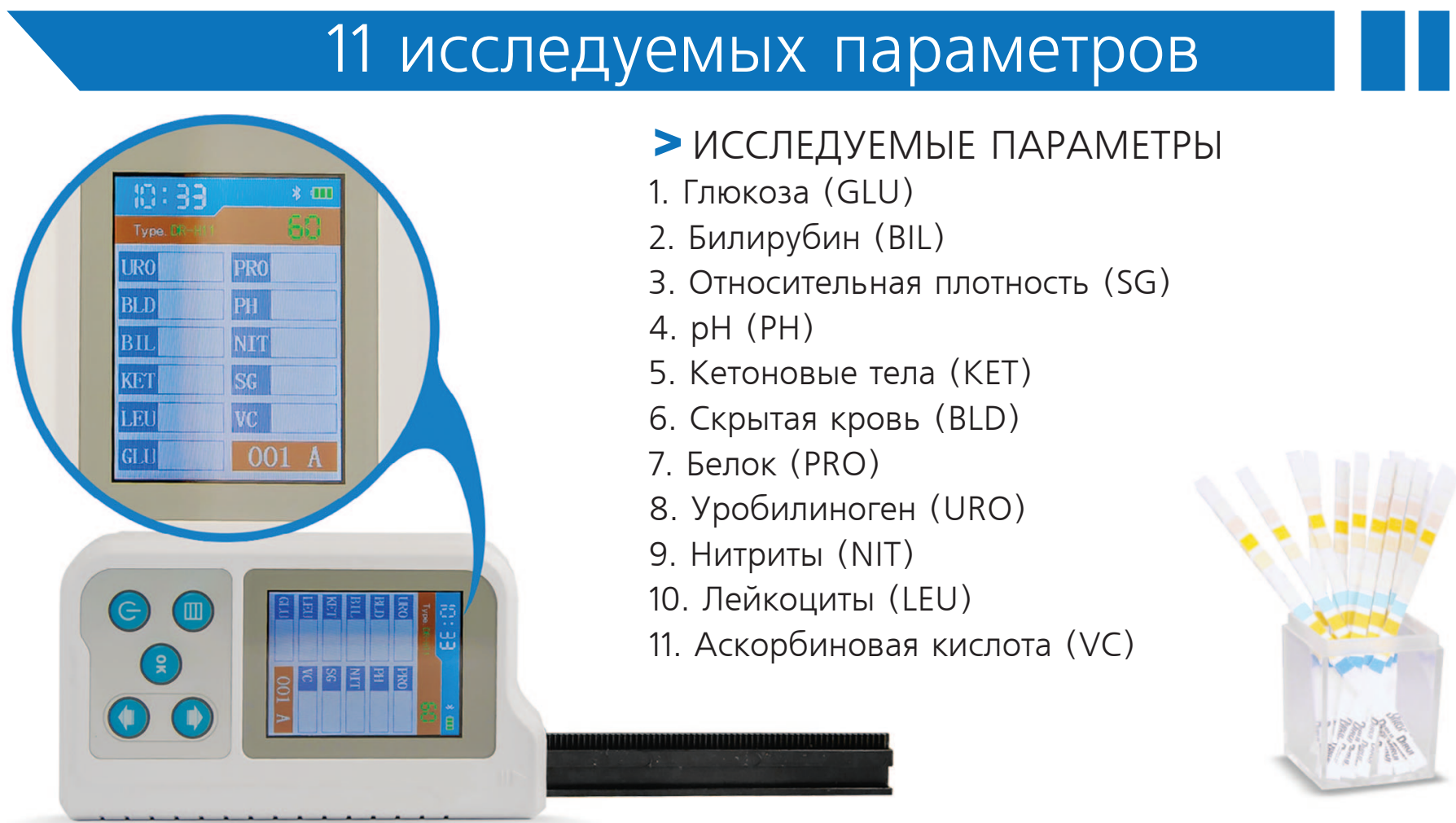




\section{РОССИЙСКИЙЖКУРНАЛТЕЛЕМЕДИЦИНЫ И ЭЛЕКТРОННОГО ЗДРАВООХРАНЕНИЯ}

Журнал зарегистрирован Федеральной службой по надзору в сорере связи, инорормационньх технологий и массовых коммуникаций, свидетельство ПИ № ФС 77 - 74021 от 19.10.2018 ISSN print 2712-9217; ISSN online 2712-9225; https://doi.org/10.29188/2712-9217

О2 июня 2021 г. в запись о регистрации СМИ внесены изменения Федеральной службой по надзору в сорере связи, инорормационных технологий и массовых коммуникаций в связи с изменением названия, изменением языка, уточнением тематики

ЦЕЛЬ ИЗДАНИЯ - инорормирование ученых, организаторов здравоохранения, практикующих врачей о реальных возможностях применения и об эфффективности различных инорормационнокоммуникационных систем в медицине.

НАУЧНАЯ СПЕЦИАЛИЗАЦИЯ - электронное здравоохранение, телемедицина, медицинская инорорматика и кибернетика, мобильное здоровье, организация здравоохранения, дистанционное обучение, страховая медицинская телематика, медицинская аппаратура, биомедицинская инженерия, биоинорорматика.

АУДИТОРИЯ - врачи всех специальностей, главные врачи ЛПУ, руководители ІТ-отделов ЛПУ, инженеры и разработчики медицинской техники и медицинского оборудования, руководители и сотрудники инорормационно-аналитических центров.

УЧРЕДИТЕЛЬ: Шадеркин Игорь Аркадьевич

Журнал представлен в Российском индексе научного цитирования (РИНЦ)

РЕДАКЦИЯ:

Издательский дом «УроМедиа»

Руководитель проекта В.А. Шадеркина

Дизайнер О.А. Белова

Редактор Д.М. Монаков, К.М.Н.

Корректор Ю.Г. Болдырева

КОНТАКТНАЯ ИНФОРМАЦИЯ:

JTelemed.ru

Российский журнал телемедицины и электронного здравоохранения

TOM 7. № 2. 1-52

https://doi.org/10.29188/2712-9217-2021-7-2

Адрес и реквизиты редакции:

Издатель: ИД «УроМедиа»: 105094 Москва, ул. Золотая, 11

Тел.: +7 (926) 017-52-14; e-mail: info@uromedia.ru; editor@jtelemed.ru; viktoriashade@gmail.com

Редакция не несет ответственности за содержание публикуемых рекламных материалов.

В статьях представлена точка зрения авторов, которая может не совпадать с мнением редакции.

Перепечатка материалов разрешается только с письменного разрешения редакции.

Отпечатано в типографии «Тверская фобрика печати».

Тираж 500 экз.

http://jtelemed.ru 


\section{Russian Journal of Telemedicine and E-Health}

The journal is registered by the Federal Service for Supervision of

communications, information technology and mass communications, certificate PI No. FS 77 - 74021 dated 19.10.2018

ISSN print 2712-9217; ISSN online 2712-9225; https://doi.org/10.29188/2712-9217

On June 2, 2021, the record on media registration was amended by the Federal Service for Supervision in the Sphere of Communications, Information Technology and Mass Media due to the change in the name, change of the language, clarification of the subject matter

THE PURPOSE OF THE JOURNAL is to inform scientists, healthcare managers, medical practitioners about the real application possibilities and the effectiveness of various information and communication systems in medicine.

THE SCIENTIFIC SPECIALIZATION OF THE JOURNAL is health, telemedicine, medical informatics and cybernetics, mobile health, healthcare organization, distance learning, medical insurance telematics, medical equipment, biomedical engineering, bioinformatics.

THE AUDIENCE OF THE JOURNAL consists of doctors of all specialties, chief doctors of healthcare facilities, heads of IT departments of healthcare facilities, engineers and developers of medical equipment, managers and employees of information and analytical centers.

FOUNDER: Igor Shaderkin

The journal is represented in the Russian Science Citation Index (RSCI)

EDITORIAL:

PUBLISHING HOUSE «UROMEDIA»

Project manager V.A. Shaderkina

Designer O.A. Belova

Editor D.M. Monakov, Ph.D.

Proofreader Yu.G. Boldyreva

CONTACT INFORMATION:

JTelemed.ru

Russian Journal of Telemedicine and E-Health

Volume 7. No. 2. 1-52

https://doi.org/10.29188/2712-9217-2021-7-2

Address and details of the editorial office:

Publisher: Publishing House «UroMedia»: 105094 Moscow, st. Zolotaya, 11

Tel .: +7 (926) 017-52-14; e-mail: info@uromedia.ru; editor@jtelemed.ru; viktoriashade@gmail.com

The editors are not responsible for the content of published advertising materials.

The articles represent the point of view of the authors, which may not coincide with the opinion of the editorial board.

Reprinting of materials is allowed only with the written permission of the publisher.

Printed at the Tver Printing Factory.

500 copies.

http://jtelemed.ru 


\section{Благодарность рецензентам}

Сотрудники редакиии «Журнала телемедииины и электронного здравоохранения» выражают огромную признательность всем экспертам, которые принимают участие в работе над каждым выпуском журнала отбирают самые качественные исследования, самые смелые экспериментальные работы, самые полные литературные обзоры и уникальные клинические случаи.

Ваша работа, коллеги, позволяет журналу повысить профессиональный уровень и предоставлять урологическому сообществу действительно новый качественный специализированный материал.

Огромное количество научных публикаций, поступающих на рассмотрение в редакцию журнала, не всегда соответствует высоким требованиям международных изданий. Вместе с редакцией наши рецензенты в свое личное время и совершенно бескорыстно выбирают достойные статьи, дорабатывают их для своевременной подготовки к публикации.

Ваши безупречные теоретические знания, бесиенный практический опыт, умение работать в команде позволяют всегда найти правильные решения, которые соответствуют иели, задачам и редакиионной политике нашего журнала.

Число рецензентов «Журнала телемедииины и электронного здравоохранения» постоянно растет в настоящее время это более 10 ученых из России и зарубежных стран.

Выражаем благодарность рецензентам за детальный и скрупулезный анализ статей «Журнала телемедииины и электронного здравоохранения» №2 за 2021 г.

\section{Суважением и благодарностью,}

\section{редакиия «Журнала телемедицины и электронного здравоохранения»}

\section{To the Reviewers: Letter of Appreciation}

The editorial board members of the "Russian Journal of Telemedicine and E-Health» is very grateful to all the experts, taking part in the workflow on each journal issue, selecting the highest quality research, the most daring experimental works, the most complete literature reviews and unique clinical cases.

Dear colleagues, your work allows to improve the journal professional level and provide the urological community with new high-quality specialized content.

A huge number of scientific publications, submitted to the journal editorial board, does not always meet the strict requirements of international publications. In cooperation with the editorial staff, our reviewers choose worthy articles and selflessly modify them for timely preparation for publication.

Your impeccable theoretical knowledge, invaluable practical experience and skill to work in a team allow you to find the only correct solutions that correspond with the goal, objectives and editorial policy of our journal.

The number of the «Russian Journal of Telemedicine and E-Health» reviewers is constantly growing - currently there are more than 10 scientists from Russia and foreign countries.

We express our gratitude to the reviewers for a detailed and thorough analysis of the articles of the "Russian Journal of Telemedicine and E-Health» № 2 (2021).

With respect and gratitude, the editorial board members of the "Russian Journal of Telemedicine and E-Health». 


\section{РЕДАКЦИОННАЯ КОЛЛЕГИЯ:}

ГЛАВНЫЙ РЕДАКТОР: Владзимирский А.В. - д.М.Н., заместитель директора по научной работе ГБУЗ

г. Москвы «НПКЦ диагностики и телемедицинских технологий ДЗМ» (Россия, Москва)

ЗАМЕСТИТЕЛЬ ГЛАВНОГО РЕДАКТОРА: ШадеркИн И.А. - К.м.Н., заведующий

лабораторией электронного здравоохранения Института циорровой медицины Первого МГМУ

им. И.М. Сеченова (Сеченовский университет, Россия, Москва)

ОТВЕТСТВЕННЫЙ СЕКРЕТАРЬ: Шадеркина В.А. - научный редактор портала Uroweb.ru (Россия, Москва)

\section{РЕДАКЦИОННЫЙ СОВЕТ ЖУРНАПА:}

Аполихин О.И. - член-корр. РАН, д.м.н, профрессор, Директор НИИ урологии и интервенционной радиологии им. Н.А. Лопаткина - фолиал ФГБУ «НМИЦ радиологии» Минздрава России (Россия, Москва)

Гусев A.В. - К.T.Н., руководитель GR-направления ассоциации «Национальная база медицинских знаний», эксперт компании «К-МИС» (Россия, Петрозаводск)

Зеленский М.М. - шефр-редактор Evercare.ru (Россия, Москва)

Калиновский Д.К. - К.М.Н., доцент кафедры хирургической стоматологии ГОО ВПО «Донецкий национальный медицинский университет им. М. Горького» (Донецк, ДНР)

Кузнецов П.П. - д.м.н., профрессор, руководитель проектного офиса «Цифровая трансформация в медицине труда» ФГБНУ «НИИ медицины труда им. академика Н.Ф. Измерова» (Россия, Москва)

Кузнецов С.С. - д.м.н. (Россия, Нижний Новгород)

Лебедев Г.С. - д.Т.Н., професссор, заведующий кафедрой инорормационных и интернет-технологий Первого МГМУ им. И.М. Сеченова (Россия, Москва)

Леванов В.М. - д.м.Н., профрессор, профрессор кафредры социальной медицины и организации здравоохранения ФГБОУ ВО "Приволжский исследовательский медицинский университет" Минздрава России (Россия, Нижний Новгород)

Монаков Д.М.- к.м.Н., врач-уролог ГБУЗ ГКБ им. С.П. Боткина (Россия, Москва)

Морозов С.П. - д.м.Н., директор ГБУЗ г. МоскВы «НПКЦ диагностики и телемедицинских технологий ДЗМ», главный внештатный специалист по лучевой и инструментальной диагностике ДЗМ и МЗ РФ по ЦФО (Россия, Москва)

Натензон М.Я., к.Т.Н., академик РАЕН, Председатель совета директоров НПО «Национальное телемедицинское а гентство» (Россия, Москва)

Огородников И.Н. - руководитель Центра разработки прикладного программного обеспечения АУ «Югорский научно-исследовательский институт инорормационных технологий» (Россия, Ханты-Мансийск)

Сивков А.В. - к.м.н., заместитель директора по научной работе НИИ урологии и интервенционной радиологии им. Н.А. Лопаткина - фрилиал ФГБУ «НМИЦ радиологии» Минздрава России (Россия, Москва)

Столяр В.Л. - к.б.Н., заведующий кафедрой медицинской иноорматики и телемедицины ФГАОУ ВО «Российский университет дружбы народов» (Россия, Москва)

Царегородцев А.Л. - К.Т.Н., доцент кафедры систем обработки инорормации, моделирования и управления ФГБОУ ВО «Югорский государственный университет» (Россия, Ханты-Мансийск)

М. Фиск - доктор наук, профрессор кафредры старения и цифрового здоровья, Школа компьютерных наук и иноорматики, Университет Де Моноор (Лестер, Великобритания)

М. Джорданова - кандидат наук, научный сотрудник Института космических исследований и технологий Болгарской академии наук (Сооия, Болгария)

Ф. Ливенс - МВА, исполнительный секретарь Международного общества телемедицины и электронного здравоохранения (Гримберген, Бельгия)

М. Марс - доктор медицинских наук, профрессор, заведующий кафредрой телемедицины Университета Квазулу-Натал (Дурбан, ЮАР)

П. Михова, - М.С., руководитель Программного совета Департамента здравоохранения и социальной работы Нового Болгарского Университета (София, Болгария)

Р. Скотт - доктор медицинских наук, профресcор, профресcор кафедры телемедицины Университета Квазулу-Натал (Дурбан, ЮАР)

А.В. Шуляк - Д.М.Н., профрессор, ГУ «Институт урологии НАМН Украины» (Киев, Украина) 


\section{EDITORIAL BOARD:}

CHIEF EDITOR: Vladzimirskyy A.V. - MD, PhD, Deputy Director for Scientific Work, Moscow State Budgetary Healthcare Institution «Scientific and Practical Center of Diagnostics and Telemedicine Technologies DZM» (Russia, Moscow)

DEPUTY CHIEF EDITOR: Shaderkin I.A. - PhD, Head of the e-Health Laboratory of the Institute of Digital Medicine of the First Moscow State Medical University them Sechenov (Sechenov University, Russia, Moscow)

EXECUTIVE SECRETARY: Shaderkina V.A. - scientific editor of the portal Uroweb.ru (Russia, Moscow)

\section{EDITORIAL BOARD OF THE JOURNAL:}

Apolikhin O.I. - Corresponding member RAS, MD, PhD, Professor, Director of the Research Institute of Urology and Interventional Radiology N. Lopatkina - branch of the Federal State Budgetary Institution «National Medical Research Center of Radiology» of the Ministry of Health of Russia (Russia, Moscow)

Gusev A.V. - Ph.D., head of the GR-direction of the association «National base of medical knowledge», expert of the company «K-MIS» (Russia, Petrozavodsk)

Zelensky M.M. - Editor-in-chief Evercare.ru (Russia, Moscow)

Kalinovsky D.K. - PhD, Associate Professor of the Department of Surgical Dentistry of the State Educational Institution of Higher Professional Education «Donetsk National Medical University named after M. Gorky» (Donetsk, DPR)

Kuznetsov P.P. - MD, PhD, Professor, Head of the Project Office «Digital Transformation in Occupational Medicine» of the FSBSI «Research Institute of Occupational Medicine. Academician N.F. Izmerov» (Russia, Moscow)

Kuznetsov S.S. - MD, PhD, (Russia, Nizhny Novgorod)

Lebedev G.S. - Doctor of Technical Sciences, Professor, Head of the Department of Information and Internet Technologies of the First Moscow State Medical University them Sechenov (Russia, Moscow)

Levanov V.M. - MD, PhD, Professor, Professor of the Department of Social Medicine and Health Organization of the Federal State Budgetary Educational Institution of Higher Education «Privolzhsky Research Medical University» of the Ministry of Health of Russia (Russia, Nizhny Novgorod)

Monakov D.M. - PhD, GBUZ GKB im. S.P. Botkina (Russia, Moscow)

Morozov S.P. - MD, PhD, Director of the State Budgetary Healthcare Institution of the city of Moscow «Research and development center for diagnostics and telemedicine technologies of the DZM», chief freelance specialist in radiation and instrumental diagnostics of the DZM and the Ministry of Health of the Russian Federation in the Central Federal District (Russia, Moscow)

Natenzon M.Ya. - Ph.D., Academician of the Russian Academy of Natural Sciences, Chairman of the Board of Directors of the NPO National Telemedicine Agency (Russia, Moscow)

Ogorodnikov I.N. - Head of the Center for the Development of Applied Software of the Autonomous Institution «Yugorsk Research Institute of Information Technologies» (Russia, Khanty-Mansiysk)

Sivkov A.V. - PhD, Deputy Director for Scientific Work of the Research Institute of Urology and Interventional Radiology named after N.A. Lopatkina - branch of the Federal State Budgetary Institution «National Medical Research Center of Radiology» of the Ministry of Health of Russia (Russia, Moscow)

Stolyar V.L. - Ph.D., Head of the Department of Medical Informatics and Telemedicine, Federal State Autonomous Educational Institution of Higher Education «Peoples' Friendship University of Russia» (Russia, Moscow)

Tsaregorodtsev A.L. - Candidate of Technical Sciences, Associate Professor of the Department of Information Processing Systems, Modeling and Control of the Federal State Budgetary Educational Institution of Higher Education «Yugorsk State University» (Russia, Khanty-Mansiysk)

M. Fisk - PhD, Professor of Ageing and Digital Health, School of Computer Science and Informatics, De Montfort University (Leicester, UK)

M. Jordanova - PhD, Researcher in Space Research \& Technology Institute, Bulgarian Academy of Sciences (Sofia, Bulgaria)

F. Lievens - MBA, Executive Secretary of International Society for Telemedicine and eHealth (Grimbergen, Belgium)

M. Mars - PhD, Professor, Head of Department of Telehealth, University of Kwazulu-Natal (Durban, South Africa)

P. Mihova, - M.S., Head of Program council, Department of Health care and Social Work, New Bulgarian University (Sofia, Bulgaria)

R. Scott - PhD, Professor, professor of Department of Telehealth, University of Kwazulu-Natal (Durban, South Africa)

Shulyak A.V. - Doctor of Medical Sciences, Professor, State Institution «Institute of Urology of the National Academy of Medical Sciences of Ukraine» (Kiev, Ukraine) 


\section{СОДЕРЖКАНИЕ}

Содержание

\section{AHAJИTMUECKMŬ OБЗ OP}

И.А. Шадеркин, В.А. Шадеркина

Дистанционные медицинские консультации пациентов: что изменилось в России за 20 лет.

\section{TIPAKTUKYIOHEMY BPAYY}

М.C. Варюшин

Правовой режим технологий искусственного интеллекта, применяемых в телемедицине.

В.М. Леванов, Е.А. Перевезенцев, О.А. Калиткина

Применение телемедицинских технологий при оказании медицинской помощи

в акушерстве и гинекологии (обзор)

\section{А.И. Мелёхин}

Дистанционная когнитивно-поведенческая терапия при лечении шума в ушах

и болезни Меньера

\section{ИСТОРИЯ ТЕЛЕМЕДИЦИНЬІ}

\section{А.В. Владзимирский}

Развитие динамической биорадиотелеметрии: ключевые исторические события. ..

\section{MHEHИE OKCIEPTA}

И.А. Шадеркин

Слабые стороны искусственного интеллекта в медицине

\section{ANALYTICAL REVIEW}

\section{I.A. Shaderkin, V.A. Shaderkina}

Remote medical consultations for patients: what has changed in Russia in 20 years ...

\section{PRACTICING PHYSICIAN}

M.S. Varjushin

Legal framework for artificial intelligence technologies in telemedicine.

V.M. Levanov, E.A. Perevezentcev, O.A. Kalitkina

Application of telemedicine technologies in medical care in obstetrics and gynecology (review).

\section{A.l. Melekhin}

Remote cognitive behavioral therapy for tinnitus and Meniere's

disease.

\section{HISTORY OF TELEMEDICINE}

\section{A.V. Vladzymyrskyy}

Evolution of dynamic bioradiotelemetry: key historical events. .

\section{EXPERT OPINION}

\section{I.A. Shaderkin}

Weaknesses of artificial intelligence in medicine. . 


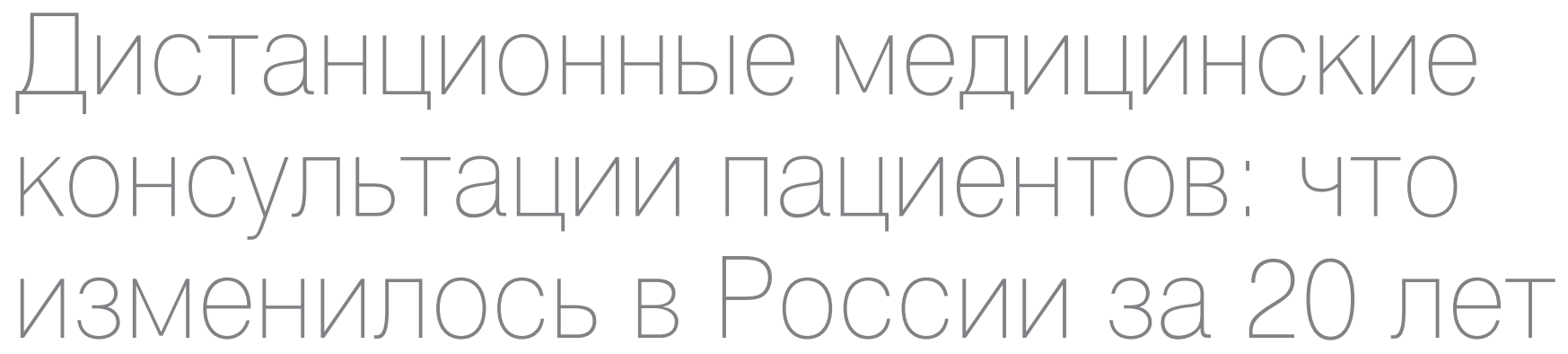

\section{Аналитический обзор}

\section{И.А. Шадеркин ${ }^{1}$, В.А. Шадеркина ${ }^{2}$}

${ }^{1}$ Институт цифрровой медицины Первого Московского государственного медицинского университета им. И.М. Сеченова (Сеченовский Университет); д. 1, стр. 2, Абрикосовский пер., Москва, 119435, Россия

2 Урологический инорормационный портал Uroweb.ru; д. 11, Золотая ул, Москва, 105094, Россия

Контакт: Шадеркина Виктория Анатольевна, viktoriashade@uroweb.ru

\section{Аннотация:}

Введение. Отмеченный пандемией 2020 год вызвал взрывной рост спроса на услуги в области телемедицины, осбенно на дистанционные консультации и дистанционный мониторинг пациентов.

Материалы и методы. Авторы проанализировали данные 169 статей из Pubmed и 47 статей из Elibrary.ru, 117 aналитических обзоров интернет-ресурсов, Федеральных Законов по ключевым словам «дистанционное консультирование пациентов», «мобильные приложения для пациентов», «телемедицина», «пандемия». Для настоящей работы были отобраны 49 публикаций, а также изложены собственное мнение и опыт авторов.

Результаты. Сегодня дистанционное консультирование в России применяется в случае первичной консультации - профрилактический прием, направление в клиники, получение второго врачебного мнения с возможностью назначения дополнительных обследований. За последние 20 лет произошел активный рост развития дистанционных консультаций, длительного мониторинга состояния здоровья пациентов, внедрение мобильных приложений для мониторинга жизненно важных показателей организма. Важным моментом является правовое регулирование положений о применении телемедицинских технологий, однако оно остается несовершенным и требует доработки. Пандемия COVID явилась драйвером развития ТМ-технологий в государственной системе здравоохранения.

Выводы. ТМ трансформировалась от обычных консультаций к длительному (непрерывному) мониторингу состояния здоровья с использованием медицинских приборов, что можно считать одним из наиболее перспективных новых направлений с клинической эфрфективностью. ТМ-технологии постепенно становятся привычным инструментом в клинической практике и могут стать рутинными для врачей и пациентов даже после окончания пандемии.

Ключевые слова: дистанционные консультации пациентов; дистанционный мониторинг пациентов; дистанционный мониторинг здоровья; пандемия COVID-19.

Для цитирования: Шадеркин И.А., Шадеркина В.А. Дистанционные медицинские консультации пациентов: что изменилось в России за 20 лет. Российский журнал телемедицины и электронного здравоохранения 2021;7(2):7-17; https://doi.org/10.29188/2712-9217-2021-7-2-7-17

\section{Remote medical consultations for patients: what has changed in Russia in 20 years Analytical overview}

https://doi.org/10.29188/2712-9217-2021-7-2-7-17

\section{I.A. Shaderkin 1 , V.A. Shaderkina ${ }^{2}$}

${ }^{1}$ Laboratory of Electronic Health, Institute of Digital Medicine, Sechenov University, Abrikosovskiy per., 1 , bldg. 2, Moscow, 119435, Russia

2 Urological information portal Uroweb.ru, Zolotaya st., 11, Moscow, 105094, Russia

Contact: Victoria A. Shaderkina, viktoriashade@uroweb.ru 


\section{Summary:}

Introduction. 2020 has sparked explosive growth in telemedicine, especially remote patient consultation and remote patient monitoring techniques.

Materials and methods. The authors analyzed data from 169 articles from Pubmed and 47 articles from Elibrary.ru, 117 analytical reviews of Internet resources, Federal Laws on the keywords «remote patient consultation», «mobile applications for patients», «telemedicine», "pandemic». For this publication, 49 publications were selected, as well as the authors' own opinions and experiences.

Results. Today remote consulting in Russia is used in the case of an initial consultation - a preventive appointment, referral to clinics, obtaining a second medical opinion with the possibility of prescribing additional examinations. Over the past 20 years, there has been an active growth in the development of remote consultations, long-term monitoring of patients' health, the introduction of mobile applications for monitoring vital signs of the body. An important point is the legal regulation of the provisions on the use of telemedicine technologies, however, it remains imperfect and requires improvement. The COVID pandemic has become a driver for the development of TM technologies in the state healthcare system.

Conclusions. TM has transformed from conventional consultations to long-term (continuous) monitoring of health status using medical devices, which can be considered one of the most promising new areas with clinical efficacy. TM technologies are gradually becoming a familiar tool in clinical practice and may become routine for doctors and patients even after the end of the pandemic.

Key words: remote patient consultations; remote patient monitoring; remote health monitoring; COVID-19 pandemic.

For citation: Shaderkin I.A., Shaderkina V.A. Remote medical consultations for patients: what has changed in Russia in 20 years. Russian Journal of Telemedicine and E-Health 2021;7(2):7-17; https://doi.org/10.29188/2712-9217-2021-7-2-7-17

\section{ВВЕДЕНИЕ}

Отмеченный пандемией 2020 год вызвал взрывной рост спроса на услуги в области телемедицины. Снижение нагрузки на системы здравоохранения путем проведения дистанционных консультаций и удаленного отслеживания показателей здоровья стало не просто желательным, но жизненно важным как для пациентов, так и для системы здравоохранения в целом. Вместе с тем эта область телемедицины, переживающая сейчас рост, активно развивалась и все предыдущее десятилетие. Дистанционные консультации пациентов развивались одновременно с распространением и обучением населения пользованию интернетом и различными коммуникационными устройствами.

\section{МАТЕРИАЛЫ И МЕТОДЬ}

Авторы проанализировали данные 169 статей из Pubmed и 47 статей из Elibrary.ru, 117 аналитических обзоров интернет-ресурсов, Федеральных Законов по ключевым словам «дистанционное консультирование пациентов», «мобильные приложения для пациентов», «телемедицина», «пандемия». Для настоящей работы были отобраны 49 публикаций, а также изложены собственное мнение и опыт авторов. Некоторые аспекты носят субъективный характер, так как интернет-ресурсы - их страницы, кон- тент - удалены за давностью лет и не могут быть процитированы.

Мы проанализировали интернет-ресурсы, на которых проводятся дистанционные консультации пациентов в доменной зоне.ru, в которую вошли сайты-«ветераны», действующие до сих пор:

- https://www.03.ru 1998-2000-2021

- https://www.consmed.ru 2006-2021

- https://03uro.ru 2000-2002-2021

Также в обзор вошли новые сервисы и приложения:

- SmartMed

- Доктор рядом

- Яндекс.Здоровье

- СберЗдоровье

\section{PESУЛBTATb}

\section{Дистанционные консультации на веб-сайтах}

С 2000 года наблюдается активное развитие различных интернет-ресурсов для проведения дистанционных консультаций пациентов [1, 2]. Как правило, они имеют мультиклинический формат - на одном ресурсе проводятся консультации врачей различных специальностей (www.03.ru, www.consmed.ru). Моноспециализированных ресурсов крайне мало, и они отличаются приверженностью одному лечебному учреждению (частные клиники - лидеры в этом 
направлении), одному врачу - личные консультации для создания имиджа группы или одного конкретного специалиста (www.03uro.ru).

Для консультативных медицинских интернет-ресурсов в период 2000-2010 г. были характерны:

- Отсутствие общих правил консультаций

- Возможность постановки диагноза, назначения лечения

- Несистемность развития - при поликлинической направленности присутствовали врачи не всех специальностей. Как правило, это было связано с уровнем внедрения интернет-технологий в конкретную специальность.

- Несовершенство технической составляющей консультаций - использовались стандартные форумы, чаты, невозможность прикрепления результатов обследований и т.д.

- Незащищенность персональных данных пациентов.

- Не все интернет-ресурсы требовали подтверждения квалификации консультирующего, а проверка подлинности предоставляемых документов крайне затруднительна.

- Завышенные ожидания и негативная реакция пациентов - пациенты надеялись полностью заменить очный визит к врачу, включая постановку диагноза и назначения лечения, в том числе рецептурных препаратов, и, не получая этого, оставались с отрицательным опытом получения дистанционной консультации.

- Со стороны врачей - фрормальный подход к проведению консультаций, использование шаблонов ответов на наиболее распространенные вопросы, максимальная конверсия заочного приема в очный.

По сути, пациент редко получал качественную врачебную консультацию.

Однако постепенно в течение 10-15 лет сорормировались основные негласные правила дистанционных консультаций:

- Не ставить диагноз, а высказывать предположение.

- Не назначать рецептурные лекарственные препараты.

- Ориентировать пациента на первичное обследование и очный прием.

- При совпадении места жительства пациента и консультирующего можно допустить конверсию в очный прием.
- По возможности рекомендовать специалиста из региона проживания пациента.

- Завершить консультацию - при необходимости довести ее до логического заключения

- Не убеждать здоровых людей в наличии у них заболевания - в некоторых случаях просто заниматься просветительной деятельностью.

- Не консультировать пациентов младше 18 лет.

Начиная с 2009-2010 г. и по 2020 г. наблюдался «взрывной» рост спроса на консультативные интернет-ресурсы - каждое лечебное учреждение, каждая кафедра, клиника, лично врач стали предлагать свои площадки для дистанционных консультаций пациентов.

Основной проблемой оставалась низкая клиническая ценность консультаций, завышенные ожидания пациентов.

Для России во многом переломным стал 2018 год, когда начал действовать принятый 29 июля 2017 г. Федеральный закон № 242 Ф3 «О внесении изменений в отдельные законодательные акты Российской Федерации по вопросам применения инорормационных технологий в сорере охраны здоровья», чаще всего называемый в обиходе «Законом о телемедицине». Сейчас ТМ прописана в Федеральном законе от 21 ноября 2011 г. № 323 [3].

Вместе с тем, как подчеркивает ряд отечественных специалистов в сорере организации здравоохранения, проработанность нормативной базы в этой области по-прежнему остается глубоко недостаточной. В частности как отмечают В.С. Половинка и соавторы, «все вышеперечисленные документы не создали правовых основ для деятельности медицинских работников в системах дистанционных осмотров или мониторинга» [4]. С одной стороны, Закон подвергся сильной критике со стороны профрессионального сообщества и бизнес-индустрии, с другой стороны - способствовал развитию отрасли.

Новыми чертами дистанционных консультаций за последние 10 лет можно считать:

- Появление качественных информационных интернет-ресурсов для пациентов, в составе которых имеется раздел для консультаций пациентов.

- Монетизация - появление офрициальных платных консультаций, - что позволило повысить как мотивацию консультирующих врачей, так и их ответственность за консультацию. 
- Изменение вектора дистанционной консультации от лидогенерации пациентов (направление в клинику) на стремление к полноценной медицинской консультации.

- Развитие и применение гаджетов для мониторинга различных показателей состояния организма стали прорывной технологией в медицине, а их активное применение в период пандемии стало жизненно необходимым для многих пациентов. Согласно недавно опубликованному отчету компании GlobalData, рынок носимых устройств в 2019 г. составлял почти $\$ 27$ млрд и, вероятно, вырастет до \$64 млрд к 2024 г. в связи с повышением озабоченности людей состоянием своего здоровья во время пандемии COVID-19, когда их серьезно интересует отслеживание контактов с зараженными людьми, прогнозирование симптомов и мониторинг здоровья [5]

- Формирование отдельного направления дистанционный мониторинг пациентов. В 2020 году был проведен поиск публикаций по использованию дистанционного мониторинга за пациентами в PubMed за период 2000-2018 гг. Анализ данных показал уверенный рост числа исследований на эту тему, причем 43\% из них были опубликованы между 2015 и 2018 гг. и показывают в целом позитивные результаты наблюдений (76,8\%). Из этих статей 38,2\% были опубликованы в США. Темой почти половины (47,8\%) от общего числа исследований стал дистанционный мониторинг при сердечно-сосудистых заболеваниях, а хирургическая патология и послеоперационный уход рассматривались лишь в 2,6\% публикаций. Наиболее популярной ожидаемо оказалась стратегия наблюдения с использованием беспроводных носимых устройств и приложений для смартфонов $(75,7 \%)$. Помимо этого, 17,6\% исследований включали в себя элементы телеобразования, а 24,6\% - телеконсультации. Авторы обзора пришли к заключению, что дистанционный мониторинг в сочетании с дистанционным консультированием максимизирует эороективность лечения и ухода за пациентами, и растущее количество публикаций доказывает высокий интерес к теме [6].

- Повышение спроса - резко возросшая потребность в консультациях со стороны пациентов. По данным ВЦИОМ 2/3 граждан РФ знают о возможности получить медицинскую помощь дистанционно, 25\% опрошенных готовы обратиться к врачу удаленно - получить прием по телефону готовы 53\% респондентов, чаще утвердительно отвечали жители Москвы, СанктПетербурга (60\%) и крупных городов-миллионников (56\%). Обратиться за консультацией через интернет предполагают 48\% опрошенных, количество допускающих онлайн-прием среди молодых людей (с 18 до 24 лет) - больше половины, 57\%. [7-9]. В одном из исследований были опрошены 301 врач общей практики и 3009 пациентов в Великобритании, Германии и Нидерландах. Исследование проводилось в ноябре 2020 года, и оно показало, что наиболее предпочтительными цифровыми инструментами, которые используют люди старше 55 лет, являются дистанционное наблюдение (50\%) и видео-обследование (50\%) [10].

В США количество пациентов, обратившихся за медицинской консультацией дистанционно за первый квартал 2020 года, увеличилось на 50\% в сравнении с аналогичным периодом 2019 года, причем большинство обращений было не по поводу COVID-19 [11]. По данным телефонного опроса ВЦИОМ на 26 мая 2020 года о возможности получить медицинскую консультацию дистанционно знали 62\% опрошенных, а в Москве эта циора составила 71\%. Однако реально воспользовались телемедицинской помощью 8\% опрошенных [12].

- Появление пакетов дистанционных медицинских услуг - разовые онлайн консультации; неограниченные онлайн консультации на различные периоды 1 месяц, 3 месяца; патронаж средним медицинским персоналом; срочные или плановые консультации [13].

- Поддержка возможности оказания удаленной медицинской помощи во время пандемии Министерством здравоохранения и закрепление этого в Приказе от 30.10.2020 г. № 1184н [14].

- Проблемой в оказании дистанционной помощи пациентам является необходимость авторизации всех пациентов, получающих телемедицинскую помощь, через портал Госуслуг. В связи с этим исключается возможность получения консультации анонимно. Технически осуществимы консультации, при которых данные пациента не видны врачу, они будут скрыты, но полная анонимность исключена.

- Еще одной проблемой со стороны врача 
можно считать необходимость консультирования строго из кабинета, имеющего лицензию по профилю на оказание телемедицинской помощи и подключенного к ЕМИАС. Это ограничивает возможности проведения консультации.

- Телемедицинские консультации могут быть оказаны только врачами, зарегистрированными в Федеральном регистре медработников и работающими в медицинской организации (ЕГИСЗ) [15].

- ТМ-платорормы сейчас названы как «иные информационные системы», а Минзрав является оператором базы реестра «иных инорормационных систем». Чтобы получить доступ к ЕСИА (единая система идентиорикации аутоинтентификации) нужно быть зарегистрированным в реестре «иных инорормационных систем». Сегодня зарегистрировано 15 систем [16].

- Важной вехой развития ТМ-технологий стало появление в номенклатуре услуг телемедицинских консультаций и удаленного мониторинга. Решение об оплате принимается на уровне субъектов тарифными комиссиями.

- На Федеральном уровне (Госуслуги) и в ряде регионов (mos.ru) появилась возможность доступа пациента к своей электронной медицинской карте [17-18].

- Сегодня дистанционное консультирование в России применяется в случае первичной консультации - профрилактический прием, направление в клиники, получение второго врачебного мнения с возможностью назначения дополнительных обследований. В силу того, что Закон строго регламентирует проведение первичной консультации, врачи игнорируют и завуалированно ставят диагноз и делают назначения. В 2020 г. в РФ обсуждался специальный правовой режим для апробации новых технологий - «цифровые песочницы», в рамках которых возможно приостановление некоторых отдельных норм закона, препятствующих тестированию этих технологий [19]. Подобные пути внедрения инноваций уже работают в Израиле, Сингапуре, США. 28 января 2021 года Федеральный закон от 31.07.2020 г. № 258-Ф3 «Об экспериментальных правовых режимах в сорере цифровых инноваций в Российской Федерации» вступил в силу [20].

- Дистанционная медицинская помощь сместилась от простого телеконсультирования к длительному дистанционному мониторингу, что выглядит крайне перспективным в плане дальнейшего развития от дискретного к непрерывному.

Если, например, раньше измерения артериального давления можно было провести только на приеме у врача, сделать общий анализ мочи и только в клинической лаборатории, то сейчас уже можно видеть непрерывное получение информации при измерении артериального давления в домашних условиях с помощью портативного тонометра или, например, получение общего анализа мочи с помощью портативного анализатора мочи, подключенных через смартфон в специальные медицинские сервисы, развивающиеся по облачным технологиям» [21-24].

Можно отметить заметный рост числа доступных аппаратных решений, предназначенных для индивидуального мониторинга фрункциональных показателей организма - фритнес-трекеров, одноканальных приборов ЭКГ, портативных анализаторов и даже холтеровского мониторинга [25].

Неотъемлемым требованием к приборам, применяемым для дистанционного мониторинга здоровья, является регистрация в Росздравнадзоре в качестве медицинского изделия [26]. Особенности регулирования выдачи разрешительной документации в РФ, формальный подход к регистрации медицинских изделий, к сожалению, приводит к тому, что на российском рынке плохо представлены решения, которые в большом количестве появляются на международном рынке.

Телемедицина в ЛПУ с государственной формой собственности

До 2010 года акцент в ЛПУ с государственной формой собственности в консультациях был на орормат «врач-врач», после 2010 года акцент сместился на формат «врач-пациент». Консультации «врач-врач» получили поддержку со стороны исполнительной власти, Минздрава РФ.

Так, например, в 2019 году были созданы НМИЦ [27], которым было вменено дистанционное консультирование врачей по соответствующим направлениям. В составе НМИЦ организованы и оснащены ТМ-центры/ТЦ-кабинеты, которые получили ффинансирование в рамках работы НМИЦ [27].

На фредеральном уровне были созданы 2 глобальные ТМ-платформы, на которых 
можно консультироваться в плановом и экстренном порядке: ТМК ФЭР (телемедицинские консультации федеральный электронный регистр плановые консультации), ЦМК «Защита» - на которой можно консультировать, в том числе экстренно [28].

Создан реестр медицинских учреждений, которые могут консультироваться на этих платформах - фредеральные учреждения, которые, как правило, консультируют врачей из регионов и ЛПУ, с государственной формы собственности 2 и 3 уровня.

Также активно развиваются региональные консультативные центры, где могут консультироваться между собой ЛПУ государственной формы 1, 2 и 3 уровней. По-прежнему остается тенденция локального развития телемедицинских консультаций и систем. В каждом субъекте представлена своя уникальная ТМ-система, на федеральном уровне эти системы контактируют между собой через единый циоровой контур.

Были введены нормативы и отчетные показатели ТМ-консультирования как в федеральных, так и региональных ЛПУ.

Ряд регионов Российской Федерации приступил к реализации собственных планов внедрения технологий дистанционного мониторинга показателей здоровья населения с возможностью последующей телеконсультации. Так, в Новгородской области с 2018 года, а в Белгородской - с фревраля 2019 года утверждены программы, нацеленные на «повышение медицинской эороективности диспансерного наблюдения и охвата населения для снижения числа обострений хронических заболеваний, связанных с развитием жизнеугрожающих состояний», в рамках которой пациент может получить у своего участкового терапевта по полису ОМС диагностический прибор нового поколения тонометр с возможностью автоматической передачи данных [29, 30].

Участие сотовых операторов в развитии телемедицины

Активное участие в развитии ТМ-технологий принимают крупнейшие российские сотовые операторы - с собственной клиентской базой и мобильными технологиями. В 2020-м году один из крупных российских операторов сотовой связи Мегафон предложил государственным и частным медучреждениям проект на базе интернета вещей для обеспечения услуг мониторинга показателей здоровья и телемедицинских консультаций. Медицинские приборы, оснащенные сим-картами оператора, должны автоматически передавать данные в облачное хранилище, где они будут агрегироваться в обезличенном виде, так что персональные данные пациента увидит только лечащий врач в предназначенном для этого интероейсе. Так же, как и в описанных ранее областных проектах, первым в распоряжение медучреждений представлено решение для удаленного мониторинга показателей здоровья пациентов с гипертонией [31].

Созданное МТС Приложение 120/80 - призвано контролировать артериальное давление с возможностью консультации с врачом, создания собственного журнала наблюдений, а совместный проект сети клиник «МЕДСИ» и телемедицинской платорормы SmartMed обеспечивает комплекс продуктов и услуг цифрового здравоохранения [32, 33].

В цифровую экосистему «Вымпелкома» «Билайнмед» включены как телемедицинские устройства для организации консилиумов (телемедицинские стойки), так и носимые устройства для мониторинга состояния здоровья пациентов (устройства, аналогичные фритнес-браслетам, но с расширенным функционалом) [34].

\section{TM-консультации в период COVID-19}

Очевидно, что вынужденное ускорение развитию технологий удаленного мониторинга и телемедицины придала пандемия COVID-19, значительно ограничившая очные контакты между людьми во всех сорерах деятельности. Ряд авторов утверждает, что область здравоохранения в целом сделала буквально десятилетний скачок всего за год борьбы с пандемией [35]. Так, например, врачи цифрового медицинского сервиса Доктор рядом, входящего в портфель VEB Ventures, в 2020 году провели 227,9 тыс. консультаций - на 293\% больше, чем в докризисном 2019-м. Выручка увеличилась на 21\% год к году, до 684,4 млн рублей [36]. Отчет об исследовании, проведенном по заказу некоммерческой организации Mobiquity, говорит, что половина пациентов в возрасте старше 55 лет во время пандемии 
предпочитали циоровые инструменты, а не личные консультации с врачом [37].

11 марта 2020 года Всемирной организацией здравоохранения (ВОЗ) было объявлено о пандемии COVID-19, поставившей системы здравоохранения всех без исключения стран в очень сложные условия и потребовавшей ряда реструктуризационных действий. В первую очередь изменениям подверглась система оказанияэкстренной и плановой медицинской помощи пациентам с COVID, а также пациентам, имеющим хронические заболевания, в том числе онкологические, без COVID. Деорицит медицинских кадров, перепродрилирование лечебных учреждений, резкое увеличение количества пациентов привело к сокращению медицинской помощи населению. Это явилось предпосылкой для снятия ряда ограничений в оказании телемедицинской помощи пациентам. В начале пандемии 20 марта было объявлено о создании Федеральных дистанционных консультативных центров по вопросам лечения COVID-19 и регламент его взаимодействия с аналогичными центрами в субъектах РФ [38], а также Временный регламент организации и оказания консультативной медицинской помощи с применением телемедицинских технологий гражданам с подтвержденным диагнозом новой коронавирусной инфрекции COVID-19, а также с признаками или подтвержденным диагнозом внебольничной пневмонии, острой респираторной вирусной инфекцией, гриппа, получающих медицинскую помощь в амбулаторных условиях (на дому). В этом документе был утвержден порядок оказания консультативной дистанционной помощи пациентам, в том числе коррекция лечения, их логистика в лечебные учреждения - при необходимости, открытие и закрытие листков нетрудоспособности, выписка электронных рецептов) [38-39].

Несомненно, появление этих документов и их реализация на практике, стали гигантским шагом в развитии телемедицинских консультаций. Остается спорным сохранение этого формата после завершения пандемии в том же объеме.

Развитие мобильных приложений для пациентов

Развитие дистанционных медицинских консультаций повлекло повышение парсипативно- сти - активного вовлечения и личного участия пациентов в диагностическом и лечебном процессе [40].

Важной вехой в развитии ТМ-консультаций стали появление и развитие мобильных приложений для пациентов. Новое исследование компании Juniper Research показало, что количество людей, использующих медицинские и оздоровительные приложения, вырастет с 627 миллионов в 2020 году до более чем 1,4 миллиарда в 2025 году [41].

Отчет компании J'son and partners consulting, обнародованный в 2014 году, также подчеркивал, что наиболее быстро растущим сегментом рынка мобильного здравоохранения выступали приложения для смартфонов, которые, в свою очередь, предлагалось разделить на четыре категории по их основным задачам:

- отслеживание показателей в области оритнеса и здоровья;

- медицинская информация (справочники, информирование, диагностика, образование);

- телемониторинг и дистанционное консультирование;

- менеджмент здравоохранения (электронные медкарты, логистическая и платежная поддержка).

В эти категории можно добавить мобильные приложения для:

- хронических пациентов

- контроля приема лекарств [42].

- контроля женского здоровья.

По данным документа Россия на момент его обнародования не входила в топ-15 стран мира: специалисты аналитической компании насчитали на тот момент лишь 16 проектов, продуктов или сервисов мобильного здравоохранения, представленных на территории РФ, однако уже тогда авторы прогнозировали существенный рост активности в этом направлении, особенно для крупных городов [43].

Однако в 2021 году прогностический обзор Grand view research уже включил Россию в ТОП20 стран, показывающих наибольшие перспективы в сорере телемониторинга показателей здоровья, телеконсультаций и мобильного здравоохранения [44].

Данные разных аналитических источников относительно объема рынка мобильных приложений телемониторинга уже в 2013 году » 
существенно разнились с оценками от 2,4 до 6,3 млрд долларов. Единогласно озвучивался лишь прогноз относительно тенденции к росту этого направления [5]. В 2018 году этот показатель оценивался уже как минимум в 8 млрд. Ожидается, что к 2025 году он превысит отметку в 111 млрд. долларов. Аналитики Zion market research отмечают высокую перспективность и востребованность технологий отслеживания показателей здоровья для людей с сахарным диабетом, ожирением, артериальной гипертензией, а также онкологическими заболеваниями. Здесь также отмечается, что по состоянию на 2017 год порядка 40\% рынка приходилось на долю США, однако прогнозируется все более заметное и быстрое развитие Азиатско-Тихоокеанского региона в этом направлении, в первую очередь за счет высокой населенности и существенной обремененности хроническими заболеваниями [45].

В 2020 году мировой рынок мобильных устройств для мониторинга здоровья, диагностических устройств и услуг оценивается в 23,1 млрд долларов. Однако в ближайшие годы он будет стремительно расти и уже к 2027 году достигнет 250,5 млрд долларов. При этом среднегодовой темп роста в период с 2020 по 2027 год составит 40,6\%. Более того, скажем, показатель для кардиомониторов прогнозируется на уровне 41,8\% в год. В абсолютном выражении этот сегмент к 2027 году достигнет 46,1 млрд долларов. И это не самый быстрорастущий сегмент. Так, продажи устройств для больных диабетом будут расти в среднем на 46,9\% в год [46].

В развитии мобильных приложений для пациентов за 2000-2020 г. можно выделить следующие аспекты:

- Резкий рост числа мобильных приложений за последние 10 лет.

- Активное участие фрармацевтических компаний и производителей медицинского оборудования в развитии рынка мобильных приложений для пациентов с различными нозологиями.

- Не всегда высокое техническое и фрункциональное качество мобильных приложений.

- Возможность авторизации несколькими путями, загрузки файлов с обследованиями.

- Вовлеченность пациентов в сохранение своего здоровья, возможность предотвращения ухудшения состояния здоровья.
- Монетизация мобильных приложений,

- Практически во всех мобильных приложениях отсутствует навязчивая реклама.

\section{Примеры реализации ТМ-технологий}

Наиболее ярким и законченным примером реализации ТМ-технологий в консультировании можно считать телемедицинские предрейсовые осмотры водителей, включающие измерение температуры тела, артериального давления, измерение алкоголя на выдохе, осмотр кожных покровов, проверка утомляемости и приема психотропных средств, общий опрос по самочувствию. Положительные стороны такого фрормата - отсутствие человеческого фрактора, жесткий регламент параметров, сокращение времени на осмотр. Недостатком является отсутствие четкой законодательной базы по этому вопросу [47-49]. Ни в одном из документов не регламентируется как именно должен проводиться медосмотр - дистанционно или очно, тем самым создается правовая неопределенность в этом вопросе.

Подчеркивалась необходимость разработки определенных алгоритмов формата дистанционного обследования, позволяющих без нарушения закона дистанционно определить фрункциональное состояние и принять решение относительно допуска или недопуска водителя или другого сотрудника по своим функциональным обязанностям. Следует отметить, что в связи с ограничениями, возникшими из-за распространения новой коронавирусной инфекции, это предложение становится лишь более актуальHым.

В ближайшие годы дистанционные консультации и удаленный мониторинг будут активно развиваться и использоваться в профилактике, диагностике и лечении пациентов. Практически во всех областях медицины возможен тот или иной способ удаленного мониторинга за пациентами.

\section{- вьноды}

1. Дистанционные технологии наблюдения и консультирования пациентов подверглись значительному развитию, трансформации и стали драйвером развития медицины и новой 
перспективой в клинических и экономических решениях

2. Действующий ФЗ, регулирующий применение ТМ-технологий, хотя и требует своего развития, явился пусковым механизмом их широкого внедрения в клиническую практику.

3. ТМ трансорормировалась от обычных консультаций к длительному (непрерывному) мониторингу состояния здоровья с использованием медицинских приборов, что можно считать одним из наиболее перспективных новых направлений с клинической эфофективностью.

4. Пандемия COVID явилась драйвером развития ТМ-технологий в государственной системе здравоохранения.

\section{5. ТМ-технологии постепенно становятся} привычным инструментом в клинической практике и могут стать рутинными для врачей.

6. Дистанционные технологии наблюдения и консультирования с применением специальных аппаратных технологий и тест-систем, стали для многих пациентов привычным и узнаваемым решением.

7. Лояльность пациентов и врачей к технологиям дистанционного мониторинга будет повышаться, а спрос будет возрастать. Завышенные ожидания остаются с обеих сторон.

8. Необходимо дальнейшее развитие и усовершенствование законодательной базы, а также финансирование телемедицинских услуг.

\section{ЛИТЕРАTYPA}

1. Аполихин О.И., Сивков А.В., Шадеркин И.А., Владзимирский А.В., Цой А.А., Зеленский М.М. Телеассистирование в диагностике и лечении урологических заболеваний. Журнал телемедицины и электронного здравоохранения 2015(1):6-9 [Apolihin O.I., Sivkov A.V., ShadYorkin I.A., Vladzimirskiy A.V., Tsoy A.A., Zelenskiy M.M. Teleassistirovanie $v$ diagnostike lechenii urologicheskih zabolevaniy. Zhurnal telemeditsinyi elektronnogo zdravoohraneniya = Journal of Telemedicine and E-Health 2015(1):6-9. (In Russian)].

2. Владзимирский А.В., Шадеркин И.А., Цой А.А., Войтко Д.А., Просянников М.Ю., Зеленский М.М. Телемедицинская веб-платформа Nethealth.ru как инструмент поддержки клинических решений в урологии. Урологические ведомости 2016(6):46-47. [Vladzimirskiy A.V., Shaderkin I.A., Tsoy A.A., Voytko D.A., Prosyannikov M.Yu., Zelenskiy M.M. Telemeditsinskaya veb-platforma Nethealth.ru kak instrument podderzhki klinicheskih resheniy $v$ urologii. Urologicheskie vedomosti $=$ Urology reports 2016(6):46-47. (In Russian)]

3. Федеральный закон от 21.11.2011 г. N 323-Ф3 (ред. от 26.05.2021 г.) «Об основах охраны здоровья граждан в Российской Федерации» Статья 36.2. Особенности медицинской помощи, оказываемой с применением телемедицинских технологий (введена Федеральным законом от 29.07.2017 N 242-Ф3). [Federalnyiy zakon ot 21.11.2011 г. N 323-FZ (red. ot 26.05.2021 г.) «Ob osnovah ohranyi zdorovya grazhdan v Rossiyskoy Federatsii» Statya 36.2. Osobennosti meditsinskoy pomoschi, okazyivaemoy s primeneniem telemeditsinskih tehnologiy (vvedena Federalnyim zakonom ot 29.07.2017 г. N 242-FZ). (In Russian)]

4. Половинка В.С., Свиридова Т.Б., Демьянков К.Б., Лотоцкий М.М. Системы дистанционного мониторинга за состоянием здоровья работников. Состояние проблемы и перспективы развития. Современные проблемы здравоохранения и медицинской статистики 2018(2):113-122. [Polovinka V.S., Sviridova T.B., Demyankov K.B., Lototskiy M.M. Sistemyi distantsionnogo monitoringa za sostoyaniem zdorovya rabotnikov. Sostoyanie problemyi i perspektivyi razvitiya. Sovremennyie problemyi zdravoohraneniya $i$ meditsinskoy statistiki $=$ Current problems of health care and medical statistics 2018 2):113-122. (In Russian)].

5. Рынок носимых устройств к 2024 г вырастет на 137\% [Электронный ресурc]. URL: https://evercare.ru/news/rynok-nosimykhustroystv-k-2024-g-vyrastet-na-137 [Ryinok nosimyih ustroystv k 2024 g vyirastet na 137\%. [Elektronnyiy resurs]. URL: https://evercare.ru/news/rynok-nosimykh-ustroystv-k-2024-g-vyrastet-na-137. (In Russian)].

6. Frederiço Arriaga Criscuoli de Farias, Carolina Matt de AssunḰ $о$ Bicca, Vincenzo Fin Falavigna, Asdrubal Falavigna. Remote Patient Monitoring: A Systematic Review. Telemed J E Health 2020 May;26(5):576-583. https://doi.org/10.1089/tmj.2019.0066.

7. ВЦИОМ: почти две трети россиян знают о телемедицине
[Электронный ресурс]. URL: https://tass.ru/obschestvo/8569303. https://tass.ru/obschestvo/8569303

8. Расширенная выборка данных ВЦИОМ [Электронный ресурс]. URL: https://profi.wciom.ru/fileadmin/file/nauka/podborka/rasshirennaya_podborka_dannyh_wciom_022021.pdf [Rasshirennaya vyiborka dannyih VTsIOM [Elektronnyiy resurs]. URL: https://profi. wciom.ru/fileadmin/file/nauka/podborka rasshirennaya_podborka dannyh_wciom_022021.pdf. (In Russian)].

9. Выборка данных ВЦИОМ. Тематический выпуск «Доверие»(7):159-161.

10. $50 \%$ пожилых пациентов предпочитают использовать циорровые средства вместо очных консультаций с врачом [Электронный ресурc]. URL: https://evercare.ru/news/50-pozhilykh-pacientovpredpochitayut-ispolzovat-cifrovye-sredstva-vmesto-ochnykh-konsultaciy [ $50 \%$ pozhilyih patsientov predpochitayut ispolzovat tsifrovyie sredstva vmesto ochnyih konsultatsiy s vrachom [Elektronnyiy resurs]. URL: https://evercare.ru/news/50-pozhilykh-pacientov-predpochitayut-ispolzovat-cifrovye-sred-stva-vmesto-ochnykh-konsultaciy. (In Russian)].

11. Koonin LM, Hoots B, Tsang CA, Leroy Z, Farris K, Jolly T, et al. Trends in the Use of Telehealth During the Emergence of the COVID-19 Pandemic - United States, January-March 2020. I Wkly Rep 2020 Oct 30;69(43):1595-1599. https://doi.org/10.15585/ mmwr.mm6943a3.

12. ВЦИОМ. Официальный сайт. [Электронный ресурс]. URL: https://wciom.ru/analytical-reviews/analiticheskii-obzor/telemediczina-v-rossii-segodnya-i-zavtra обращение 8.05.2021 [VTsIOM. Ofitsialnyiy sayt. [Elektronnyiy resurs]. URL: https://wciom.ru/ analytical-reviews/analiticheskii-obzor/telemedicz-ina-v-rossiisegodnya-i-zavtra obraschenie 8.05.2021. (In Russian)].

13. Медицинский онлайн-сервис СберЗдоровье. Официальный сайт. [Электронный ресурc]. URL: https://www.sberbank.com/ ru/eco/sberhealth

14. Приказ Министерства здравоохранения Российской Федерации от 30.10.2020 г. № 1184н «0 внесении изменений в приказ Министерства здравоохранения Российской Федерации от 19 марта 2020 г. № 198н «0 временном порядке организации работы медицинских организаций в целях реализации мер по профилактике и снижению рисков распространения новой коронавирусной инфекции COVID-19» (Зарегистрирован 12.11.2020 № 60860).

15. Федеральный регистр медицинских работников [Электронный ресурс]. URL: https://support.egisz.rosminzdrav.ru/ index.php?/Knowledge/List/Index/63 [Prikaz Ministerstva zdravoohraneniya Rossiyskoy Federatsii ot 30.10.2020 \# 1184n «O vnesenii izmeneniy v prikaz Ministerstva zdravoohraneniya Rossiyskoy Federatsii ot 19 marta 2020 g. \# 198n «O vremennom poryadke or ganizatsii rabotyi meditsinskih organizatsiy v tselyah realizatsii mer po profilaktike i snizheniyu riskov rasprostraneniya novoy koronavirusnoy infektsii SOVID-19» (Zareg- 
JUTEPATYPALA 16. Федеральный закон от 27.07.2006 Г. N 149-Ф3 (ред. от 09.03.2021 г.) «Об информации, информационных технологиях и о защите информации" (с изм. и доп., вступ. в силу с 20.03.2021 г.)» [Электронный ресурc]. URL: http://www.consultant.ru/document/cons_doc_LAW_61798/41021e09a57b2 db1834266a1635d5a7a7a9e $7 \mathrm{ce}$ / [Federalnyiy zakon ot 27.07.2006 N 149-FZ (red. ot 09.03.2021) «Ob informatsii, informatsionnyih tehnologiyah i o zaschite informatsii" (s izm. i dop., vstup. v silu s 20.03.2021)» [Elektronnyiy resurs]. URL: http://www.consultant.ru/document/cons_doc_LAW_61798/41021e09a57b2db183 4266a1635d5a7a7a9e7ce9/. (In Russian)].

17. Госуслуги [Электронный ресурс]. URL: https://gostelemed.ru/ gosuslugi/faq [Gosuslugi [Elektronnyiy resurs]. URL: https://gostelemed.ru/gosuslugi/faq. (In Russian)].

18. Офрициальный сайт мэра Москвы. Электронная карта. [Электронный ресурc]. URL: https://www.mos.ru/city/projects/medcarta/ [Ofitsialnyiy sayt mera Moskvyi. Elektronnaya karta.[Elektronnyiy resurs]. URL: https://www.mos.ru/city/projects/medcarta/. (In Russian)].

19. Ли И. Телемедицина и беспилотники: зачем нужны «цифровые песочницы» [Электронный ресурc]. URL: https://tass.ru/obschestvo/10903733 [Li I. Telemeditsina i bespilotniki: zachem nuzhnyi «tsifrovyie pesochnitsyi» [Elektronnyiy resurs]. URL: https://tass.ru/obschestvo/10903733. (In Russian)]

20. Федеральный закон от 31.07.2020 г. № 258-Ф3 «Об экспериментальных правовых режимах в сфере цифровых инноваций в Российской Федерации)» [Электронный ресурс]. URL: http://www.kremlin.ru/acts/bank/45796 [Federalnyiy zakon ot 31.07 .2020 g. \# 258-FZ «Ob eksperimentalnyih pravovyih rezhimah v sfere tsifrovyih innovatsiy v Rossiyskoy Federatsii)» [Elektronnyiy resurs]. URL: http://www.kremlin.ru/acts/ bank/45796. (In Russian)].

21. Посненкова О.М., Коротин А.С., Киселев А.Р., Гриднев В.И. Оценка эфффективности технологии дистанционного мониторинга артериального давления у больных артериальной гипертонией на основе показателей выполнения клинических рекомендаций. Кардио-ИТ 2015;2(2):e0203. [Posnenkova OM, Korotin AS, Kiselev AR, Gridnev VI. Evaluation the effectiveness of remote blood pressure monitoring technology in patients with hypertension on the basis of clinical recommendations performance measures. Kardio-IT = Cardio-IT 2015;2(2):e0203. (In Russian)]. 22. Гарманова Т.Н., Шадеркин И.А., Цой А.А. Дистанционный мониторинг пациента после эндоскопической коррекции устья правого мочеточника. Экспериментальная и клиническая урология 2016(4):122-126. [Garmanova T.N., Shaderkin I.A., Tsoy A.A. Distantsionnyiy monitoring patsienta posle endoskopicheskoy korrektsii ustya pravogo mochetochnika. Eksperimentalnaya $\mathrm{i}$ klinicheskaya urologiya $=$ Experimental and Clinical Urology 2016(4):122-126. (In Russian)].

23. Шадеркин И.А., Владзимирский А.В., Цой А.А., Войтко Д.А., Просянников М.Ю., Зеленский М.М. Диагностическая ценность портативного анализатора мочи ЭТТА АМП-01 как инструмента самостоятельного мониторинга в mHealth и при скрининге в первичном звене медицинской помощи. Урологические ведомости 2016;6(S):105-106. [Shaderkin I.A., Vladzimirskiy A.V., Tsoy A.A., Voytko D.A., Prosyannikov M.Yu., Zelenskiy M.M. Diagnosticheskaya tsennost portativnogo analizatora mochi ETTA AMP-01 kak instrumenta samostoyatelnogo monitoringa $v$ mealth i pri skrininge $v$ pervichnom zvene meditsinskoy pomoschi. Urologicheskie vedomost $i=$ Urology reports 2016;6(S):105-106. (In Russian)].

24. Лебедев Г.С., Шадеркин И.А., Фомина И.В., Лисненко А.А., Рябков И.В., Качковский С.В., Мелаев Д.В. Эволюция интернет-технологий в системе здравоохранения. Журнал телемедицины и электронного здравоохранения 2017;3(2):63-78. [Lebedev G.S., Shaderkin I.A., Fomina I.V., Lisnenko A.A., Ryabkov I.V., Kachkovskiy S.V., Melaev D.V. Evolyutsiya internet-tehnologiy $v$ sisteme zdravoohraneniya. Zhurnal telemeditsinyi i elektronnogo zdravoohraneniya = Journal of Telemedicine and E-Health 2017;3(2):63-78. (In Russian)]. 25. Горожанцев Ю.Н., Сергиенко С.Г., Воротынцева Е.А., Емельяненко Ю.В. Дистанционное холтеровское многосуточное мониторирование - перспективное направление в развитии телемедицины. Инновационная медицина Кубани 2018(10)2:62-72.
[Gorozhantsev Yu.N., Sergienko S.G., Vorotyintseva E.A., Emelyanenko Yu.V. Distantsionnoe holterovskoe mnogosutochnoe monitorirovanie - perspektivnoe napravlenie v razvitii telemeditsinyi. Innovatsionnaya meditsina $\mathrm{Kubani}=$ Innovative Medicine of Kuban 2018(10)2:62-72. (In Russian)].

26. Постановление Правительства РФ от 27 декабря 2012 г. N 1416 «Об утверждении Правил государственной регистрации медицинских изделий» [Электронный ресурс]. URL: https://base.garant.ru/70291692/ [Postanovlenie Pravitelstva RF ot 27 dekabrya 2012 g. N 1416 «Ob utverzhdenii Pravil gosudarstvennoy registratsii meditsinskih izdeliy» [Elektronnyiy resurs]. URL: https://base.garant.ru/70291692/. (In Russian)]. 27. Приказ Министерства здравоохранения РФ от 7 апреля 2021 г. N 309 «Об утверждении Положения о формировании сети национальных медицинских исследовательских центров и об организации деятельности национальных медицинских исследовательских центров» [Электронный ресурc]. URL: https://www.garant.ru/ products/ipo/prime/doc/400547704/ [Prikaz Ministerstva zdravoohraneniya RF ot 7 aprelya 2021 g. N 309 «Ob utverzhdenii Polozheniya o formirovanii seti natsionalnyih meditsinskih issledovatelskih tsentrov i ob organizatsii deyatelnosti natsionalnyih meditsinskih issledovatelskih tsentrov» [Elektronnyiy resurs]. URL: https://www.garant.ru/products/ ipo/prime/doc/400547704/. (In Russian)].

28. Портал оперативного взаимодействия участников ЕГИСЗ Офрициальный сайт. [Электронный ресурc]. URL: https://portal.egisz.rosminzdrav.ru/materials/3245 [Portal operativnogo vzaimodeystviya uchastnikov EGISZ. Ofitsialnyiy sayt. [Elektronnyiy resurs]. URL: https://portal.egisz.rosminzdrav.ru/materials/3245. (In Russian)].

29. Медвестник: Мониторинг изменит систему. [Электронный ресурс]. URL: https://medvestnik.ru/content/interviews/ Monitoring-izmenit-sistemu.html) (Доступ 16.03.21). [Medvestnik: Monitoring izmenit sistemu. [Elektronnyiy resurs]. URL: https://medvestnik.ru/content/interviews/Monitoring-izmenitsistemu.html) (Dostup 16.03.21). (In Russian)].

30. Департамент здравоохранения Белгородской области. Внедрение дистанционного мониторинга состояния здоровья больных хроническими неинфекционными заболеваниями с использованием персональных приборов и систем искусственного интеллекта. http://www.belzdrav.ru/novosti/ vnedrenie-distancionnogo-monitoringa-sostoyaniya-z/ [Электронный ресурc]. URL: http://www.belzdrav.ru/novosti/vnedrenie-distancionnogo-monitoringa-sostoyaniya-z/. [Departament zdravoohraneniya Belgorodskoy oblasti. Vnedrenie distantsionnogo monitoringa sostoyaniya zdorovya bolnyih hronicheskimi neinfektsionnyimi zabolevaniyami $s$ ispolzovaniem personalnyih priborov i sistem iskusstvennogo intellekta. http://www.belzdrav.ru/novosti/vnedrenie-distancionnogo-monitoringa-sostoyaniya-z/. (In Russian)].

31. Ведомости. МегаФон запускает решение для дистанционного мониторинга здоровья. [Электронный ресурс]. URL: https://www.vedomosti.ru/press_releases/2020/07/23/ megafon-zapuskaet-reshenie-dlya-distantsionnogo-monitoringazdorovya) (Доступ 15.03.21). [Vedomosti. MegaFon zapuskaet reshenie dlya distantsionnogo monitoringa zdorovya. [Elektronnyiy resurs]. URL: https://www.vedomosti.ru/press releases/2020/07/23/megafonzapuskaet-reshenie-dlya-distantsionnogo-monitoringa-zdorovya) (Dostup 15.03.21). (In Russian)].

32. Приложение МTC 120/80: помощь людям с высоким давлением. [Электронный ресурс]. URL: https://media.mts.ru/ technologies/186632/ [Prilozhenie MTS 120/80: pomosch Iyudyam s vyisokim davleniem. [Elektronnyiy resurs]. URL: https://media.mts.ru/technologies/186632/. (In Russian)] 33. SmartMed - это приложение для смартфона на iOS или Android. [Электронный ресурc]. URL: https://medsi.ru/lands/ smartmed.php [SmartMed - eto prilozhenie dlya smartfona na iOS ili Android. [Elektronnyiy resurs]. URL: https:/medsi.ru/lands/ smartmed.php. (In Russian)].

34. Билайн Бизнес запускает сервис телемедицины для корпоративных клиентов. [Электронный ресурc]. URL: https://moskva.beeline.ru/about/press-center-new/press-releases/details/1484065/ [Bilayn Biznes zapuskaet servis telemeditsinyi dlya korporativnyih klientov. [Elektronnyiy resurs]. URL: https://moskva.beeline.ru/about/press-centernew/press-releases/details/1484065/ (In Russian)].

35. Philips. Healthcare has made 10 years of progress in just a few 
months. Here's how. [Электронный ресурc]. URL: https://www.philips. com/a-w/about/news/archive/blogs/innovation-matters/2020/20200618healthcare-has-made-10-years-of-progress-in-just-a-few-monthsheres-how.html. (Доступ 11.03.21) [Philips. Healthcare has made 10 years of progress in just a few months. Here's how. [Elektronnyiy resurs] URL: https://www.philips.com/a-w/about/news/archive/blogs/innovation-matters/2020/20200618-healthcare-has-made-10-years-ofprogress-in-just-a-few-months-heres-how.html. (Dostup 11.03.21). (In Russian)].

36. Доктор рядом в 2020 году увеличил число консультаций вчетверо. [Электронный ресурс]. URL: https://evercare.ru/ news/doktor-ryadom-v-2020-godu-uvelichil-chislo-konsultaciyvchetvero [Doktor ryadom v 2020 godu uvelichil chislo konsultatsiy vchetvero. [Elektronnyiy resurs]. URL: https://evercare.ru/ news/doktor-ryadom-v-2020-godu-uvelichil-chislo-konsultaciyvchetvero. (In Russian)].

37. 50\% пожилых пациентов предпочитают использовать цифровые средства вместо очных консультаций с врачом. [Электронный реcypc]. URL: https://evercare.ru/news/50-pozhilykh-pacientov-predpochitayut-ispolzovat-cifrovye-sredstva-vmesto-ochnykh-konsultaciy [50\% pozhilyih patsientov predpochitayut ispolzovat tsifrovyie sredstva vmesto ochnyih konsultatsiy s vrachom. [Elektronnyiy resurs]. URL: https://evercare.ru/news/50-pozhilykh-pacientov-predpochitayut-ispolzovatcifrovye-sred-stva-vmesto-ochnykh-konsultaciy. (In Russian)].

38. Приказ Министерства здравоохранения РФ от 19 марта 2020 г. № 198н «0 временном порядке организации работы медицинских организаций в целях реализации мер по профилактике и снижению рисков распространения новой коронавирусной инфекции COVID19». [Электронный ресурc]. URL: http://www.consultant.ru/document/cons doc LAW 348101/ [Prikaz Ministerstva zdravoohraneniya RF ot 19 marta 2020 g. \# 198n «0 vremennom poryadke organizatsii raboty meditsinskih organizatsiy $v$ tselyah realizatsii mer po profilaktike i snizheniyu riskov rasprostraneniya novoy koronavirusnoy infektsii COVID-19». [Elektronnyiy resurs]. URL:http://www.consultant.ru/document/cons_doc_ LAW_348101/. (In Russian)].

39. Приложение 18 к приказу Министерства здравоохранения Российской Федерации от 19 марта 2020 г. N 198н. [Электронный реcypc]. URL: http://www.consultant.ru/document/cons doc LAW 348101/5284cfe3d3845d754c4e0bcca0e8b26c21cc12bc/ [Prilozhenie $18 \mathrm{k}$ prikazu Ministerstva zdravoohraneniya Rossiyskoy Federatsii ot 19 marta 2020 g. N 198n. [Elektronnyiy resurs]. URL: http://www.consultant.ru/docu-ment/cons_doc_LAW_348101/5284cfe3 d3845d754c4e0bcca0e8b26c21cc12bc/. (In Russian)].

40. Шадеркин И.А., Шадеркина В.А. Удаленный мониторинг здоровья: мотивация пациентов. Журнал телемедицины и электронного здравоохранения 2020(3):37-43. [Shaderkin I.A., Shaderkina V.A. Udalennyiy monitoring zdorovya: motivatsiya patsientov. Zhurnal telemeditsinyi $i$ elektronnogo zdravoohraneniya = Journal of Telemedicine and E-Health 2020(3):37-43. (In Russ-

\section{Сведения об авторах:}

Шадеркин И.А. - к.м.н., заведующий лабораторией электронного здравоохранения Института цифровой медицины Первого Московского государственного медицинского университета им. И.М. Сеченова; Москва, Россия; info@uroweb.ru; РИНЦ Author ID 695560

Шадеркина В.А. - научный редактор урологического инорормационного портала UroWeb.ru; Москва, Россия;

viktoriashade@uroweb.ru; РИНЦ Author ID 880571

\section{Вклад автора:}

Шадеркин И.А. - дизайн исследования, написание текста, 50\% Шадеркина В.А. - литературный обзор, написание текста, 50\%

Конфрликт интересов: авторы заявляют об отсутствии конфрликта интересов.

Финансирование: Исследование проведено без спонсорской поддержки

Статья поступила: 21.02.21

Принята к публикации: 24.04.21 ian)]. https://doi.org/10.29188/2712-9217-2020-6-3-37-43 41. Juniper: K 2025 г. будет насчитываться 1,4 млрд пользователей медицинских и оздоровительных приложений. [Электронный ресурc]. URL: https://evercare.ru/news/juniperk-2025-g-budet-naschityvatsya-14-mlrd-polzovateley-medicinskikh-i-ozdorovitelnykh.

42. Благовещенская О.К. Конкурентный анализ приложений с фрункцией уведомления о времени приема препарата. Российский экономический вестник 2021;4(1):192-196. [Blagoveschenskaya O.K. Konkurentnyiy analiz prilozheniy $s$ funktsiey uvedomleniya o vremeni priema preparata. Rossiyskiy ekonomicheskiy vestnik = Russian Economic Bulletin 2021;4(1):192-196. (In Russian)].

43. J'son and partners consulting, Рынок мобильной медицины в России и в мире: основные тенденции и прогнозы. [Электронный ресурс]. URL: https://json.tv/ict_telecom_analytics_view/rynok-mobilnoy-meditsiny-v-rossii-i-v-mire-osnovnye-tendentsii-i-prognozy).

44. Grand View research, mHealth Apps Market Size, Share \& Trends Analysis Report By Type (Fitness, Medical), By Region (North America, APAC, Europe, MEA, Latin America), And Segment Forecasts, 2021-2028. [Electronic resource]. URL: https://www.grandviewresearch.com/industry-analysis/mhealthapp-market.

45. Zion Market Research. Global mHealth Apps Market Will Reach USD 111.1 Billion By 2025. [Electronic resource]. URL: https://www. globenewswire.com/news-release/2019/01/24/1704860/0/en/GlobalmHealth-Apps-Market-Will-Reach-USD-111-1-Billion-By-2025-ZionMarket-Research.html.

46. Mobile Health Monitoring, Diagnostic Devices and Services - Global Market Trajectory \& Analytics. [Electronic resource]. URL: https://www. researchandmarkets.com/reports/5140488/mobile-health-monitoringdiagnostic-devices-and?utm_source=ixbtcom.

47. ст.23 ч.7 Федеральный закон от 10 декабря 1995 г. №196Ф3 «0 безопасности дорожного движения». [st.23 ch.7 Federalnyiy zakon ot 10 dekabrya $1995 \mathrm{~g}$. \#196-FZ «0 bezopasnosti dorozhnogo dvizheniya». (In Russian)].

48. п.10 ст.10 Федерального закона от 21 ноября 2011 г. №323Ф3 «Об основах охраны здоровья граждан в Российской Федерации». [р.10 st.10 Federalnogo zakona ot 21 noyabrya 2011 g. \#323-FZ «Ob osnovah ohranyi zdorovya grazhdan v Rossiy-skoy Federatsii». (In Russian)].

49. Приказ Министерства здравоохранения РФ от 30 ноября 2017 г. №965н «Об утверждении порядка организации и оказания медицинской помощи с применением телемедицинских технологий». [Prikaz Ministerstva zdravoohraneniya RF ot 30 noyabrya $2017 \mathrm{~g}$. \#965n «Ob utverzhdenii poryadka organizatsii i okazaniya meditsinskoy pomoschi s primeneniem telemeditsinskih tehnologiy». (In Russian)].

\section{Information about authors:}

Shaderkin I.A. - PhD, Head of the Laboratory of Electronic Health, Institute of Digital Medicine, Sechenov University; Moscow, Russia; info@uroweb.ru; https://orcid.org/0000-0001-8669-2674

Shaderkina V.A. - Scientific editor of the urological information portal UroWeb.ru; Moscow, Russia; viktoriashade@uroweb.ru;

https://orcid.org/0000-0002-8940-4129

Author contributions:

Shaderkin I.A. - research design, text writing, 50\%

Shaderkina V.A. - literature review, text writing, 50\%

Conflict of interest: The authors declare no conflict of interest.

Financing: The study was performed without external funding 


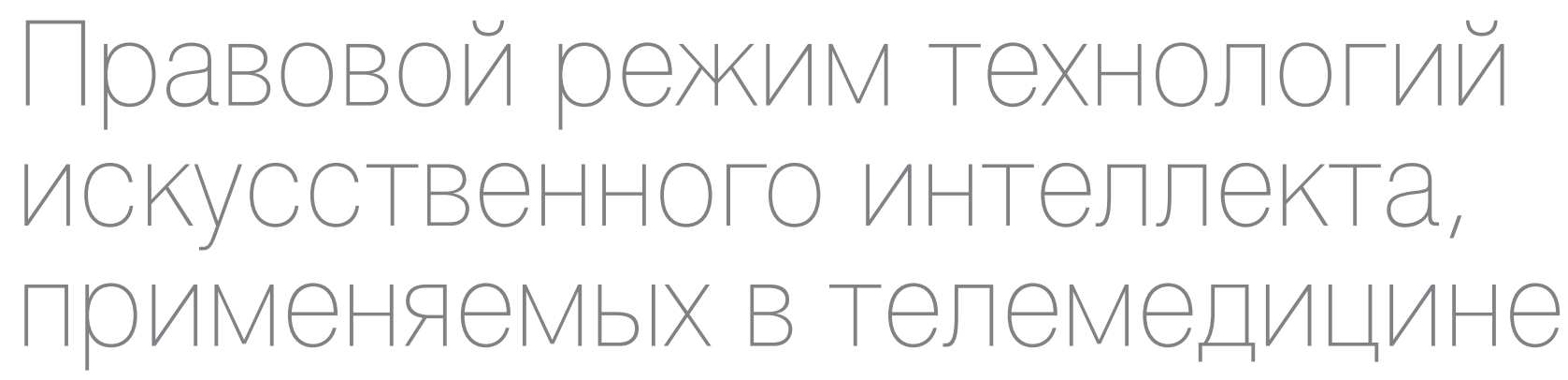

\section{Литературный обзор}

\section{М.C. Варюшин}

Частная адвокатская практика; Москва, Россия

Контакт: Варюшин Михаил Сергеевич, varyushinms@gmail.com

\section{Аннотация:}

Юридические аспекты применения технологий искусственного интеллекта (ТИИ) в здравоохранении интенсивно развиваются. В настоящее время медицинские организации сталкиваются с применением ТИИ в условиях недостаточного правового регулирования. Представлен анализ юридических аспектов применения технологий искусственного интеллекта в рамках дистанционного взаимодействия медицинских работников между собой и с пациентами (законными представителями). Приведены рекомендации для руководителей медицинских организаций при внедрении и применении технологий ИИ в разных режимах. Детально разобран вопрос гражданско-правовой ответственности за вред, причиненный при оказании медицинской помощи с использованием технологий ИИ.

Ключевые слова: искусственный интеллект; правовой статус; законодательство; ответственность; врач.

Для цитирования: Варюшин М.С. Правовой режим технологий искусственного интеллекта, применяемых в телемедицине. Российский журнал телемедицины и электронного здравоохранения 2021;7(2);18-22; https://doi.org/10.29188/2712-9217-2021-7-2-18-22

\section{Legal framework for artificial intelligence technologies in telemedicine Literature review}

https://doi.org/10.29188/2712-9217-2021-7-2-18-22

\section{M.S. Varjushin}

Private law practice; Moscow, Russia

Contact: Mihail S. Varjushin, varyushinms@gmail.com

\section{Summary:}

Regulation of artificial intelligence (Al) technologies in healthcare are rapidly developing. Currently, medical organizations faced with the use of Al in conditions of insufficient legislation. There is an analysis of the Al's legal aspects in the frame of distant interaction of doctors each other and with patients via telemedicine. Special recommendations for introducing and applying Al technologies in different modes given for medical organizations managers The issue of civil liability for harm caused during the provision of medical care using Al technologies analyzed in detail.

Key words: artificial intelligence; legislation law; responsibility; doctor.

For citation: Varjushin M.S. Legal framework for artificial intelligence technologies in telemedicine. Russian Journal of Telemedicine and E-Health 2021;7(2):18-22; https://doi.org/10.29188/2712-9217-2021-7-2-18-22 


\section{口 ВВЕДЕНИЕ}

В последнее время искусственный интеллект (далее - «ИИ») все чаще используется в медицине, например, при распознавания медицинских изображений, разработке лекарственных препаратов, в протезировании и т.п. Технологии ИИ также востребованы и в телемедицине. Онлайн сервисы постановки «предварительного» диагноза с помощью нейросетей запустили некоторые крупные игроки рынка цифровой медицины. В работу медицинских организаций активно внедряются системы поддержки принятия врачебных решений на основе распознания медицинских изображений при диагностике онкологических, лор-заболеваний и т.п. [1-4]. Причем неотьемлемой часть таких сервисов является также телемедицинское консультирование по модели «врачврач», когда требуется привлечение специалиста, например, лечащим врачом-терапевтом, использующим технологии ИИ в своей работе с пациентами [5]. ИИ позволяет маршрутизировать пациентов телемедицинских сервисов, существенно облегчая работу врачам-терапевтам, которые раньше выполняли такую фрункцию.

При этом, несмотря на то что ИИ становится существенной частью рынка телемедицины, его правовой режим до конца не определен [6, 7]. Термин ИИ в российском законодательстве определяется как «комплекс технологических решений, позволяющий имитировать когнитивные фрункции человека (включая самообучение и поиск решений без заранее заданного алгоритма) и получать при выполнении конкретных задач результаты, сопоставимые как минимум с результатами интеллектуальной деятельности человека (См. пункт 5 Указа Президента РФ «О развитии искусственного интеллекта в Российской Федерации» от 10.10.2019 г. № 490). ИИ включает информационные системы, информационно-телекоммуникационные сети, технические средства обработки информации, программное обеспечение, процессы и сервисы по обработке данных и поиску решений.

В качестве объекта права ИИ в телемедицине в первую очередь представлен программами для ЭВМ, которые могут быть как медицинскими изделиями, так и программным обеспечением, используемым в сорере цифррового здравоохранения и медицинскими базами данных, в том числе обезличенных данных.

\section{- PEГИCTPAHИG МЕДИபИНСКИХ ИЗдЕЛИЙ}

Пункт 2 Правил государственной регистрации медицинских изделий (утв. Постановление Правительства РФ от 27 декабря 2012 г. № 1416) устанавливает, что государственной регистрации как медицинское изделие в Росздравнадзоре подлежит специальное программное обеспечение, предназначенное для профрилактики, диагностики, лечения и медицинской реабилитации заболеваний, мониторинга состояния организма человека, проведения медицинских исследований, восстановления, замещения, изменения анатомической структуры или фризиологических фрункций организма, предотвращения или прерывания беременности, ффункциональное назначение которых не реализуется путем фрармакологического, иммунологического, генетического или метаболического воздействия на организм человека. Это означает, что программное обеспечение должно быть предназначено производителем (разработчиком) для медицинских целей.

Согласно Критериям отнесения продукции к медицинским изделиям в части программного обеспечения (утв. Протоколом Комиссии по выдаче заключений на запросы, связанные с обращением медицинских изделий ФГБУ «ВНИИИМТ » Росздравнадзора № 03 от 28 января 2020 года), программное обеспечение относится к медицинским изделиям при условии, если оно:

а) не является составной частью другого медицинского изделия;

б) предназначено производителем для оказания медицинской помощи;

в) результат его действия заключается в интерпретации в автоматическом режиме, в том числе с использованием технологий искусственного интеллекта, или по заданным медицинским работником параметрам, влияющим на принятие клинических решений, набора данных, полученных от медицинских изделий, допущенных к обращению в установленном порядке или введенных медицинскими работниками в целях оказания медицинской помощи.

Программное обеспечение с использованием ИИ относится к 3 классу медицинских изделий, то есть с высокой степенью риска. Это обуславливает также то, что сведения о наличии (отсутствии) в программном обеспечении, являющемся медицинским изделием, технологий ИИ и их " 
описание подлежат обязательному указанию в технической документации в составе регистрационного досье (См. пункт 5.1 Приказа Минздрава России «Об утверждении требований к содержанию технической и эксплуатационной документации производителя (изготовителя) медицинского изделия» От 19.01.2017 г. N 11н).

Помимо того, что ИИ прямо предусмотрен в перечне видов медицинских изделий, для его регистрации с 05 декабря 2020 года требуется представлять сведения, подтверждающие клиническую эороективность и безопасность медицинских изделий, при этом вводится ускоренная одноэтапная процедура государственной регистрации (см. Постановление Правительства РФ от 24.11.2020 г. № 1906), что говорит о повышенном внимании государства к подобным разработкам.

В целях легализации использования обезличенных медицинских данных при обучении ИИ были внесены изменения в положения о фредеральной интегрированной электронной медицинской карте (далее - «ЭМК»). Так, ЭМК должна обеспечивать хранение наборов обезличенных медицинских данных для их использования в целях создания алгоритмов и методов машинного обучения для формирования систем поддержки принятия врачебных решений, создания и применения технологических решений на основе искусственного интеллекта; поддержку разработки технологических решений на основе искусственного интеллекта; хранение, фрункционирование и верификацию технологических решений на основе искусственного интеллекта; доступ медицинских организаций к технологическим решениям на основе искусственного интеллекта (см. Постановление Правительства РФ «О внесении изменений в Положение о единой государственной информационной системе в сорере здравоохранения» от 19.12.2020 г. № 2174).

Собственно, при деперсонализации медицинская документация, например, в виде снимков, и раньше могла использоваться для обучения ИИ при наличии согласия пациента на обработку его персональных данных. Деперсонализованные данные утрачивают характеристики, предусмотренные Федеральным законом «О персональных данных» от 27.07.2006 г. № 152-Ф3, то есть не позволяют идентифицировать человека ни по отдельности, ни в совокупности, и могут быть переданы другим операторам как обычные данные, утратив- шие признаки не только данных специальной категории, но и персональных данных в принципе.

Такие базы данных являются самостоятельными объектами интеллектуальной собственности и принадлежат как правило медицинским организациям, которые их составляют. Но если медицинская организация просто передает обезличенные деперсонализованные данные разработчикам ИИ, то база данных орормируется уже разработчиком ИИ, а не медицинской организацией. И именно он получает исключительные права на такую базу данных.

ИИ в составе информационных систем могут использоваться и без регистрации в качестве медицинских изделий в соответствии с Федеральным законом от 24.04.2020 г. № 123-Ф3 и Федеральным законом от 31.07.2020 г. № 258-Ф3 (см. Приказ Минздрава России от «О временном порядке организации работы медицинских организаций в целях реализации мер по профиллактике и снижению рисков распространения новой коронавирусной инфекции COVID-19» 19.03.2020 г. № 198н).

При этом, что касается ИИ поддержки принятия врачебных решений, то до их регистрации в качестве медицинских изделий они могут быть внедрены в работу медицинских организаций в рамках системы внутреннего контроля качества и безопасности медицинской деятельности.

Контроль качества и безопасности медицинской деятельности согласно статье 87 Федерального закона «Об основах охраны здоровья граждан в Российской Федерации» от 21.11.2011 г. № 323-Ф3 осуществляется в том числе в фрорме внутреннего контроля, например, путем создания системы оценки деятельности медицинских работников, участвующих в оказании медицинских услуг.

Медицинская организация должна разработать положение о порядке организации и проведения внутреннего контроля качества и безопасности медицинской деятельности согласно Требованиям к организации и проведению внутреннего контроля качества и безопасности медицинской деятельности (утв. Приказом Минздрава России от 07.06.2019 г. № 381н) и включить в положение ИИ как один из элементов контроля.

Внутренний контроль может включать следующие мероприятия: оценку качества и безопасности медицинской деятельности медицинской организации, ее структурных подразделений путем проведения плановых и целевых (внеплановых) проверок, а также сбор статистических дан- 
ных, характеризующих качество и безопасность медицинской деятельности медицинской организации, и их анализ. ИИ может использоваться при оценке качества и безопасности медицинской деятельности медицинской организации. Результаты ИИ, полученные в ходе анализа фото и видео материалов медицинских обследований, на основании которых ИИ выявлены отклонения в установленных медицинскими работниками диагнозах от вероятностного диагноза, установленного ИИ, могут быть предметом рассмотрения врачебной комиссией.

\section{- ВРАЧЕБНАЯ КОМИССИЯ}

Врачебная комиссия состоит из врачей и возглавляется руководителем медицинской организации или одним из его заместителей. Она осуществляет оценку качества, обоснованности и эфорективности лечебно-диагностических мероприятий, а также разработку мероприятий по устранению и предупреждению нарушений в процессе диагностики и лечения пациентов (см. пункт 4 Порядка создания и деятельности врачебной комиссии медицинской организации (утв. Приказом Минздравсоцразвития России от 5 мая 2012 г. № 502н).

При внедрении ИИ в работу медицинской организации руководителем медицинской организации должен быть выпущен приказ о внедрении ИИ в работу, с которым медицинские работники, вовлеченные в работу с ИИ, должны быть ознакомлены под роспись. Также рекомендуется внести соответствующие изменения в должностные инструкции таких медицинских работников.

Вопрос гражданско-правовой ответственности за вред, причиненный при оказании медицинской помощи с использованием технологий ИИ, также остается открытым [8].

В том случае, когда ИИ не зарегистрирован как медицинское изделие и используется медицинской организацией исключительно в рамках системы внутреннего контроля качества и безопасности оказываемой медицинской помощи, медицинский работник, оказывающий медицинскую помощь, может использовать ИИ исключительно в целях проверки своей деятельности, например, правильности и точности поставленного им диагноза. Но постановка окончательного диагноза медицинским работником осуществляется самостоятельно. Поскольку ИИ в данном случае не яв- ляется медицинским изделием, используемым медицинским работником непосредственно при оказании медицинской помощи пациенту, то вред здоровью, причиненный пациенту вследствие недостатков ИИ, возмещается непосредственно медицинской организацией с возможностью последующего обращения с иском к разработчику ИИ. Условия ответственности разработчика ИИ следует предусматривать в соответствующем лицензионном соглашении или договоре об отчуждении исключительных прав на ИИ.

Если ИИ зарегистрирован как медицинское изделие, то причиненный здоровью пациента вред будет также возмещаться медицинской организацией. Но следует учесть фракт того, что ни клинические рекомендации, ни порядки оказания медицинской помощи не содержат правил, позволяющих медицинскому работнику при диагностике или выборе лечения пациента использовать ИИ. Это означает, что полностью снять ответственность с медицинского работника, осуществившего манипуляции, основываясь на выводах о состоянии здоровья пациента, полученных исключительно с использованием ИИ, нельзя. Медицинская организация, а также медицинский работник (в рамках регрессного иска медицинской организации, работодателя, к виновному в причинении вреда жизни и здоровью пациента медицинскому работнику) не могут быть освобождены от ответственности до тех пор, пока в клинических рекомендациях либо порядках оказания медицинской помощи не будут закреплены соответствующие положения о возможности использования ИИ. При причинении вреда здоровью пациента при оказании ему медицинской помощи с использованием ИИ все-таки причинителем вреда (без учета вины) будет медицинская организация, которая в свою очередь вправе предъявить соответствующий регрессный иск к разработчику (правообладателю) ИИ, если вред последовал в результате ошибок в работе ИИ, а не в следствие действий медицинского работника.

\section{- Выноды}

Технологии искусственного интеллекта развиваются достаточно стремительно. С ними связывают надежды на циоровую трансформацию системы здравоохранения. Нормативно-правовое регулирование соответствующих аспектов продолжает интенсивно развиваться. 


\section{ЛИTЕPATYPA}

1. Yu KH, Beam AL, Kohane IS. Artificial intelligence in healthcare. Nat Biomed Eng 2018 Oct;2(10):719-731. https://orcid.org/10.1038/ s41551-018-0305-z.

2. O'Sullivan S, Nevejans N, Allen C, Blyth A, Leonard S, Pagallo U, Holzinger K, Holzinger A, Sajid MI, Ashrafian H. Legal, regulatory, and ethical frameworks for development of standards in artificial intelligence (Al) and autonomous robotic surgery. Int J Med Robot 2019 Feb;15(1):e1968. https://orcid.org/10.1002/rcs.1968.

3. Свиридова Е.А. Проблема ответственности искусственного интеллекта через призму концепции гражданско-правовой ответственности Франции. Образование и право 2020(4):516-523.

[Sviridova E.A. Problema otvetstvennosti iskusstvennogo intellekta cherez prizmu koncepcii grazhdansko-pravovoj otvetstvennosti Francii. Obrazovanie i pravo = Education and Law 2020(4)516-523. (In Russian)].

4. Морозов С.П., Владзимирский А.В., Ледихова Н.В., Андрейченко А.Е., Арзамасов К.М., Баланюк Э.А., Гомболевский В.А., Ермолаев С.О., Живоденко В.С., Идрисов И.М., Кирпичев Ю.С., Логунова Т.А., Нуждина В.А., Омелянская О.В., Раковчен В.Г., Слепушкина А.В. Московский эксперимент по применению компьютерного зрения в лучевой диагностике: вовлеченность врачей-рентгенологов. Врач и информационные технологии 2020(4):14-23. [Morozov S.P., Vladzimirskij A.V., Ledihova N.V., Andrejchenko A.E., Arzamasov K.M., Balanjuk Je.A., Gombolevskij V.A., Ermolaev S.O., Zhivodenko V.S., Idrisov I.M., Kirpichev Ju.S., Logunova T.A., Nuzhdina V.A., Omeljanskaja O.V., Rakovchen V.G., Slepushkina A.V. Moskovskij jeksperiment po primeneniju komp'juternogo zrenija $\mathrm{v}$ luchevoj diagnostike: vovlechennost' vrachej-rentgenologov. Vrach $i$ informacionnye tehnologii = Information Technologies for the Physician 2020(4):14-23.

\section{Сведения об авторе:}

Варюшин М.С. - юрист, к.ю.н., частная адвокатская практика; Москва, Россия; varyushinms@gmail.com

\section{Вклад автора:}

Варюшин М.С. - определение научного интереса, дизайн исследования, сбор данных, написание текста, 100\%

Конфликт интересов: Автор заявляют об отсутствии коноликта интересов.

Финансирование: Исследование выполнено без спонсорской поддержки.

\section{Статья поступила: 29.04.21}

Принята к публикации: 25.05.21
(In Russian)].

5. Морозов С.П., Владзимирский А.В., Варюшин М.С., Аронов А.В. Распределение ответственности за некачественное оказание медицинской помощи при использовании телемедицинских технологий. Журнал телемедицины и электронного здравоохранения 2018;1-2(6-7):9-15. [Morozov S.P., Vladzymyrsyyj A.V., Varyushin M.S., Aronov A.V. Raspredelenie otvetstvennosti za nekachestvennoe okazanie medicinskoj pomoshhi pri ispol'zovanii telemedicinskih tehnologij. Zhurnal telemediciny i jelektronnogo zdravoohranenija = The Journal of Telemedicine and e-Health 2018;1-2(6-7):9-15. (In Russian)].

6. Исмаилов И.Ш. Искусственный интеллект: правовой статус, проблемы десриниции и перспективы использования в юриспруденции. Проблемы экономики и юридической практики 2019;5(15):135-139. [Ismailov I.Sh. Iskusstvennyj intellekt: pravovoj status, problemy definicii i perspektivy ispol'zovanija v jurisprudencii. Problemy jekonomiki i juridicheskoj praktiki = Economic problems and legal practice 2019;5(15):135-139. (In Russian)].

7. Берггольц В.В. Правовой статус и разграничение ответственности при разработке и использовании инструментов искусственного интеллекта. Международный журнал гуманитарных и естественных наук 2020;6-3(45):23-27. [Berggol'c V.V. Pravovoj status i razgranichenie otvetstvennosti pri razrabotke i ispol'zovanii instrumentov iskusstvennogo intellekta. Mezhdunarodnyj zhurnal guamanitarnyh i estestvennyh nauk = International Journal of Humanities and NaturalSciences 2020;6-3(45):23-27. (In Russian)].

8. Neri E, Coppola F, Miele V, Bibbolino C, Grassi R. Artificial intelligence: Who is responsible for the diagnosis? Radiol Med 2020 Jun;125(6):517-521. https://orcid.org/10.1007/s11547-020-01135-9.

\section{Information about author:}

Varjushin M.S. - Private law practice; Moscow, Russia; varyushinms@gmail.com

\section{Author contributions:}

Varjushin M.S. - definition of scientific interest, research design, data collection, text writing, 100\%

Conflict of interest: The author declare no conflict of interest.

Financing: The study was performed without external funding.

\section{Received: 29.04 .21}

Accepted for publication: 25.05.21 


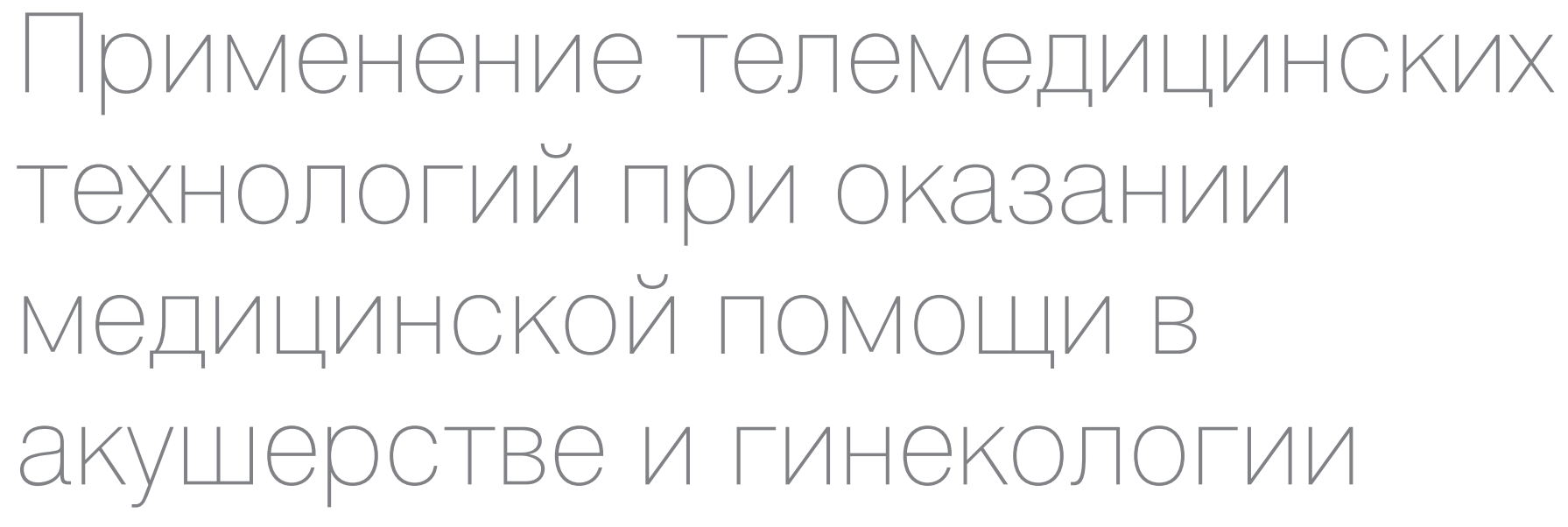

Питературный обзор

\section{В.М. Леванов ${ }^{1,2}$, Е.А. Перевезенцев ${ }^{1}$, О.А. Калиткина ${ }^{1}$}

1 ФГБОУ ВО «Приволжский исследовательский медицинский университет» Минздрава России; д.10/1, пл. Минина и Пожарского, Нижний Новгород, 603005, Россия

2 ГНЦ РФ - Институт медико-биологических проблем РАН; д.76А, стр.10, Хорошевское шоссе, Москва, 123007, Россия

Контакт: Леванов Владимир Михайлович, levanov53@yandex.ru

\section{Аннотация:}

Введение. Телемедицинские технологии находят все более широкое применение в различных направлениях медицины. Не являются исключением такие дисциплины, как акушерство, гинекология. Был проведен поиск в российских и международных базах данных. Релевантные статьи были отобраны для детального изучения.

Цель исследования. Провести поиск публикаций, посвященных применению телемедицинских технологий в области акушерства и гинекологии, осуществить анализ и систематизацию, и на основе представленного в статьях опыта определить состояние, проблемы и перспективы развития телеакушерства и телегинекологии.

Материалы и методы. Статистический поиск научных статей на профрильных зарубежных и российских сайтах, поиск информации на сайтах медицинских учреждений, наукометрический.

Результаты. С 1999 года по 2018 год количество работ колеблется от одной до четырех в год. В 2019-2020 г. отмечается значительный рост числа публикаций, что отражает резкое повышение интереса к теме применения телемедицины в акушерстве и гинекологии. В 2020 году скачок (рост на 62\% по сравнению с 2019 годом) обусловлен распространением коронавирусной инфекции. Так, среди всех статей за 2020 год $42 \%$ посвящены условиям COVID-19.

Выводы. Применение ТМТ в акушерстве и гинекологии имеет хорошие перспективы, так как позволяет повысить доступность, качество и безопасность медицинской помощи, что особенно актуально в условиях пандемии COVID-19.

Ключевые слова: телемедицина; телеакушерство; телегинекология; циоровые технологии; телеконсультации.

Для цитирования: Леванов В.М., Перевезенцев Е.А., Калиткина О. Применение телемедицинских технологий при оказании медицинской помощи в акушерстве и гинекологии (обзор). Российский журнал телемедицины и электронного здравоохранения 2021;7(2)23-30; https://doi.org/10.29188/2712-9217-2021-7-2-23-30 


\author{
Application of telemedicine technologies in medical care in obstetrics and gynecology \\ Literature review \\ https://doi.org/10.29188/2712-9217-2021-7-2-23-30

\section{V.M. Levanov ${ }^{1,2}$, E.A. Perevezentsev ${ }^{1}$, O.A. Kalitkina ${ }^{1}$} \\ ${ }^{1}$ FGBOU VO Privolzhsky research medical University, Ministry of health of Russia. 10/1, sq. Minin and \\ Pozharsky, Nizhny Novgorod, 603005, Russia \\ ${ }^{2}$ GNC RF - Institute of biomedical problems of the RAS. 76A, bldg 10, Khoroshevskoe highway, Moscow, \\ 123007, Russia
}

Contacts: Vladimir M. Levanov, levanov53@yandex.ru

\title{
Summary:
}

Introduction. Telemedicine technologies are increasingly being used in various areas of medicine. Such disciplines as obstetrics and gynecology are no exception.

Purpose. A search was conducted in Russian and international databases.

Materials and methods. Relevant articles were selected for detailed study. 65 articles were found on the review topic for the period 1999-2020, including 8 Russian ones, with a significant increase in publications in 2019-2020.

Results. When analyzing the subject of articles, it was revealed that most of them are devoted to remote monitoring of women during pregnancy and the postpartum period, correction of somatic pathology (arterial hypertension, diabetes mellitus), and mental problems. There has been an increase in publications on telegynecology in connection with the COVID-19 pandemic.

Conclusions. In comparison with some other areas of telemedicine, the number of publications on teleobstetrics and telegynecology is small, but their growth in recent years and the existing experience of implemented projects show the prospects for their development.

Key words: telemedicine; teleobstetrics; telegynecology; digital technologies; teleconsultations.

For citation: Levanov V.M., Perevezentsev E.A., Kalitkina O.A. Application of telemedicine technologies in medical care in obstetrics and gynecology (review). Russian Journal of Telemedicine and E-Health 2021;7(2)23-30; https://doi.org/10.29188/2712-9217-2021-7-2-23-30

\section{ВВЕДЕНИЕ}

Телемедицинские технологии находят все более широкое применение в различных направлениях медицины. Не являются исключением такие дисциплины, как акушерство, гинекология. Был проведен поиск в российских и международных базах данных. Релевантные статьи были отобраны для детального изучения. По теме обзора найдено 65 статей за период 1999 - 2020 гг., в том числе 8 российских, со значительным ростом публикаций за последние два года. При анализе тематики статей выявлено, что большинство из них посвящено дистанционному наблюдению за женщинами во время беременности и в послеродовой период, коррекции соматической патологии (артериальная гипертония, сахарный диабет), психических проблем. Отмечается рост публикаций по телегинекологии в связи с пандемией COVID-19. По сравнению с некоторыми другими направлениями телемедицины число публикаций по телеакушертву и телегинекологии невелико, однако их рост в последние годы и имеющийся опыт реализованных проектов показывают перспективность их развития.

\section{актуальHOCTВ}

Телемедицинские технологии (ТМТ) находят все более широкое распространение в различных сорерах здравоохранения. В Федеральном проекте «Создание единого цифррового контура в здравоохранении на основе единой государственной информационной системы в сфрере здравоохранения (ЕГИСЗ)», входящем в Национальный проект «Здравоохранение», предусмотрено, 
что к концу 2022 г. во всех регионах страны будет фонкционировать централизованная подсистема «Телемедицинские консультации» [1].

Известно, что ТМТ, и в частности, телеконсультации, неравномерно используются в различных клинических специальностях, что обусловлено, в том числе спецификой заболеваний, объемом и видами необходимой для врачаконсультанта диагностической инорормации, возможностью ее цифровой визуализации, передачи и другими факторами.

Актуальность исследования обусловлена востребованностью применения телемедицинских технологий в акушерстве и гинекологии.

Цель исследования: провести поиск публикаций, посвященных применению телемедицинских технологий в области акушерства и гинекологии, осуществить анализ и систематизацию, и на основе представленного в статьях опыта определить состояние, проблемы и перспективы развития телеакушерства и телегинекологии.

\section{МАТЕРИАЛЫ| И МЕТОДЫ}

Методы исследования: статистический, поиск научных статей на профрильных зарубежных и российских сайтах, поиск информации на сайтах медицинских учреждений, наукометрический.

Для фрормулировки англоязычных терминов при поиске были использованы медицинские предметные заголовки (Medical Subject Headings $\mathrm{MeSH})$, сорормированы такие поисковые запросы: «teleobstetrics», «telegynecology», «teleconsultations», telemedicine AND «obstetrics» OR «gynecology» OR «abortion» OR «pregnancy».

Аналогичные поисковые операции были проведены в Научной электронной библиотеке для поиска русскоязычных публикаций - «телегинекология» или «телеакушерство»; «инорормационные технологии» и «гинекология» и «акушерство».

Результаты запросов: PubMED - 57; НЭБ - 9.

Результаты поиска были актуальны по состоянию на 31.03.2021 г. Релевантные полнотекстовые статьи в количестве 21 были отобраны для детального изучения.

Кроме того, авторы сочли возможным включить в обзор 4 материала, размещенных в 2017 2020 г. в Интернете, которые принадлежат сайтам клиник и иллюстрируют современные при- меры информационных ресурсов по исследуемой проблеме.

\section{口 РЕЗУЛЬТАТЬ}

Научные исследования, посвященные применению телемедицины в акушерстве и гинекологии, начались в середине 20 века. Одними из первых научных работ были статьи, в которых приведено использование телемедицины в виде дидактического телевидения в акушерско-гинекологических клиниках и проведение клинических лекций посредством телевидения [2-3].

В этот период времени начинает развиваться использование телеметрических систем в перинатальной медицине [4]. Например, с 1973 года в США происходит формирование телемедицинских акушерских сетей между районными больницами и медицинскими центрами для осуществления телеконсультаций наиболее сложных пациентов с получением рекомендаций касательно тактики их ведения по телеорону. Эфффекты внедрения подобных способов связи между специалистами разных уровней оказались достаточно продуктивными как в плане улучшения качества оказания акушерской помощи, так и снижения оринансовых затрат, что послужило источником распространения системы в других странах, например, в 1975 году в Японии.

Во многих европейских странах уделялось внимание применению дистанционных технологий для проведения непрерывного медицинского образования врачей акушеров-гинекологов с целью улучшения их профессиональной подготовки.

В России первые публикации, посвященные применению телемедицинских и телеобразовательных технологий в области акушерства и гинекологии появились на рубеже XX и XXI веков. Дистанционные технологии нашли свое применение в оказании акушерской помощи, для решения перинатальных проблем, а также для повышения квалификации специалистов [5-6].

На рисунке 1 изображен график, отражающий количество научных работ по применению телемедицины в акушерстве и гинекологии в зависимости от даты публикации.

Как видно из диаграммы, интерес к тематике проявился несколько лет назад. С 1999 года » 


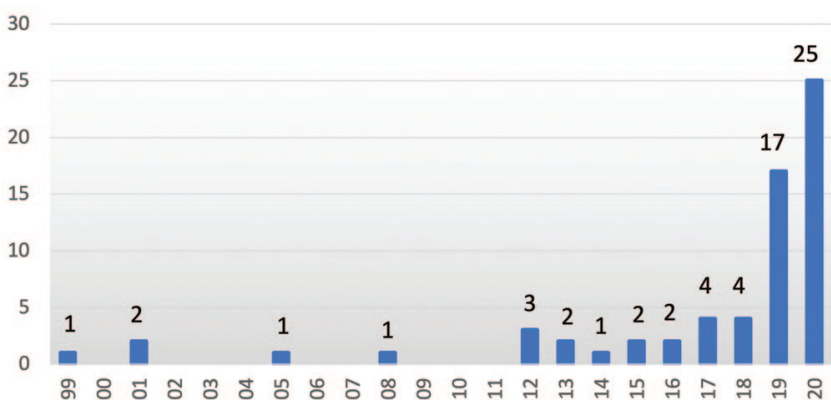

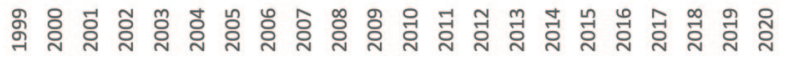

Рис. 1. Динамика количества статей, посвященных телеакушерству и телегинекологии, за 1999-2020 г. (в абсолютных числах)

Fig. 1. Dynamics of the number of articles on tele-obstetrics and telegynecology for 1999-2020 (in absolute numbers)

по 2018 год количество работ колеблется от одной до четырех в год. В 2019-2020 г. отмечается значительный рост числа публикаций, что отражает резкое повышение интереса к теме применения телемедицины в акушерстве и гинекологии. В 2020 году скачок (рост на 62\% по сравнению с 2019 годом) обусловлен распространением коронавирусной инфекции. Так, среди всех статей за 2020 год 42\% посвящены условиям COVID-19 [7].

На диаграмме представлены основные направления научных работ в сорере применения телемедицины в акушерстве и гинекологии за все годы, начиная с 1999 г. (рис. 2). Отметим, что некоторые исследования могут быть отнесены к нескольким группам одновременно.

Из рисунка 2 видно, что свыше 70\% научных работ посвящены теме применения телемедицинских технологий при ведении беременности
(26.3\%), проведению абортов (15,8\%), внедрению и апробации новых технологий (15.8\%). За последний год в связи с актуальностью возросло число статей, посвященных различным аспектам гинекологической и акушерской помощи в условиях пандемии.

\section{ОБСУХХЕНИЕ}

Авторами статей приводится опыт дистанционного наблюдения за женщинами, беременность или послеродовой период которых осложняется артериальной гипертензией, приемом опиоидов, сахарным диабетом и психическими проблемами. В научных работах, посвященных ведению беременности с артериальной гипертензией (далее - АГ), отмечается, что внедрение дистанционного консультирования показало высокую эфффективность и удовлетворенность медицинской помощью среди участниц исследования, способствовало снижению частоты госпитализаций в послеродовом периоде с тяжелыми проявлениями АГ [8].

Подчеркивается, что использование телемедицины способствует уменьшению количества осложнений, а также упрощает коммуникацию во время беременности с врачами других специальностей, например, анестезиологами $[9,10]$. В некоторых научных работах рассматривается опыт дистанционного контроля у беременных женщин опиоидной зависимости, сахарного диабета, развития или прогрессирования

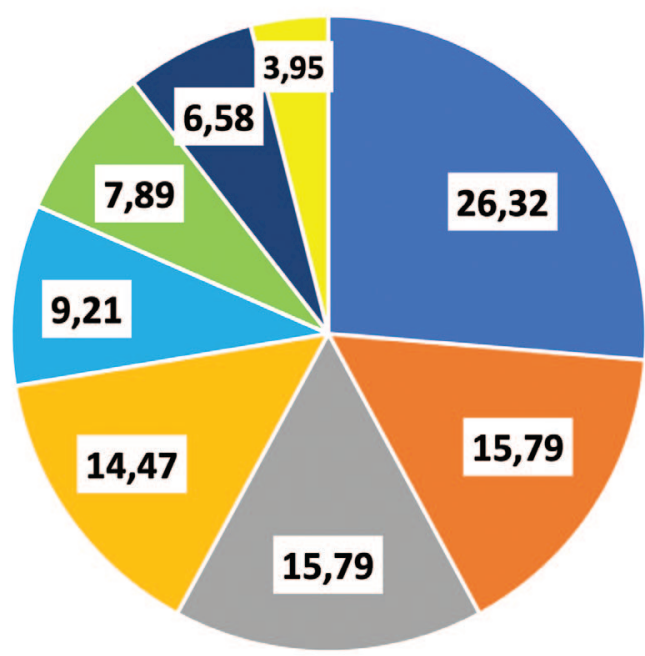

Ведение беременности

Проведение аборта

Внедрение технологий

COVID-19

Обзорные статьи

Гинекологические заболевания

— Дистанционные технологии

Анестезиология и

реаниматология

Рис. 2. Основная тематика публикаций, посвященных телеакушерству и телегинекологии, за 1999-2020 г. (в процентах)

Fig. 2. The main topics of publications devoted to tele-obstetrics and telegynecology, 1999-2020 (in percent) 
психических заболеваний, в том числе послеродовой депрессии и профилактики материнского суицида. Отмечается, что это не только экономически эфорективно, но и значительно снижает риски невынашивания беременности, преждевременных родов [11].

Опыт проведения медицинских абортов с применением телемедицинских технологий также является востребованным в современной науке. Так, в некоторых статьях подчеркивается, что телемедицинский аборт позволяет женщинам обратиться к специалисту в более короткие сроки. Также проведенные исследования свидетельствуют о том, что неблагоприятные события при дистанционно проведенном аборте также редки, как и при обычном аборте. В работах отмечается высокая удовлетворенность женщин таким подходом, так как в результате применения телемедицинских технологий снижается количество личных посещений, оринансовых затрат и эмоциональной нагрузки, связанных с очным приемом и увеличением времени ожидания приема специалиста лично. Телемедицинский аборт понимается как предоставление всех следующих услуг: оценка и консультирование перед абортом, медикаментозное лечение аборта, инструкции по лечению и последующее наблюдение, посредством любой формы устного или письменного обмена информацией, происходящего между женщиной и лицом, которое берет на себя медицинскую ответственность за оценку или содержание предоставленной информации.

Были выбраны исследования, в которых телемедицина использовалась для комплексного медицинского обслуживания абортов, то есть оценки/консультирования, лечения и последующего наблюдения, отчетности об успешности (продолжение беременности, полный аборт и хирургическая эвакуация), безопасности (скорость переливания крови и госпитализации) или приемлемости (удовлетворенность, неудовлетворенность и рекомендация службы) [12].

Другая группа статей отражает опыт внедрения новых технологий для диагностики и лечения заболеваний с применением телемедицинских технологий $[13,14]$.

Некоторые исследования описывают результаты дистанционного мониторинга плода, состояния его сердечно-сосудистой системы, проведения цитогенетического анализа, дистанционного УЗИ и КТГ в сельских районах, где невозможно лично обратиться к специалисту. Так, была научно обоснована возможность и целесообразность, безопасность и информативность использования методики дистанционной кардиотокографии в диагностике ранних признаков повреждения плода при плацентарной недостаточности в динамике III триместра беременности [15].

Не менее интересным является использование Систем поддержки принятия врачебных решений (СППВР) в акушерской практике [16]. В целях реализации этой системы разрабатываются приложения для мобильных устройств. В результате исследований было установлено, что внедрение подобных технологий не только повышает возможность наблюдения за женщинами в труднодоступных районах, но и уменьшает сроки ожидания и расходы, связанные с оказанием акушерско-гинекологической помощи.

Использование телемедицины для консультаций женщин в связи с лечением и профилактикой гинекологических заболеваний также получило свое распространение в научных исследованиях. Дистанционные технологии нашли свое применение в лечении бесплодия, ведении онкологических пациентов, а также женщин с воспалительными заболеваниями органов репродуктивной системы и нарушениями тазового дна. Онлайн-консультации дают возможность наблюдения за пациентами в сельской местности, а также увеличивают обращаемость подростков за гинекологической помощью.

Необходимость оказания помощи в акушерско-гинекологическом проориле при угрозе распространения коронавирусной иноекции вывела телемедицину на первый план. Так, в 2020 году появились исследования дистанционного мониторинга беременных с высоким риском, гинекологическими заболеваниями и проведением удаленного аборта в условиях COVID-19. В работах отмечается, что оказание медицинской помощи таким образом позволяет снизить риски заражения пациентов, медицинских работников и дает возможность вести наблюдение за состоянием пациентов, которым в данный момент невозможно оказание плановой помощи очно.

Телемедицина в акушерстве и гинекологии является не только предметом исследования 
науки, но и применяется в практике. Рассмотрим несколько примеров на основе данных сайтов учреждений здравоохранения. Так, например, в презентации КБУЗ «Медицинский центр - Управляющая компания Алтайского медицинского кластера» в 2010 году выделяется телеакушерство и телеконсультирование данных УЗИ как способ дистанционной диагностики врожденных аномалий развития плода и проведения консультирования женщин по вопросам беременности, что должно прийти на смену самостоятельно организующимся сообществам граждан, в которых может распространяться недостоверная информация.

В 2016 г. ФГБУ «Научный центр акушерства, гинекологии и перинатологии им. академика В.И. Кулакова» Минздрава России представил отчет о своем опыте работы в телемедицинском центре. Телекоммуникационная система позволила проводить ежедневные консультации пациентов из многих округов РФ. Основными причинами обращения были различные патологии плода, акушерские и экстрагенитальные патологии женщин, послеоперационные осложнения, уточнение диагноза или тактики лечения. Кроме того, рассматривается внедрение единой концепции телемедицинских технологий, которая позволит обеспечивать связь медицинских работников и учреждений, проводить профрессиональные конференции, а также осуществлять удаленное обучение, в том числе с применением симуляционно-тренинговых технологий [17].

В 2020 году ФГБУ "ВЦМК Защита" Минздрава России была организована телемедицинская конференция для врачей по разным профилям, в том числе акушерству и гинекологии. Рассматривались аспекты применения клинических рекомендаций, репродуктивной медицины, продемонстрированы показательные операции, проведен симуляционный тренинг и освящены другие вопросы данной сореры.

Дистанционную консультацию акушера-гинеколога можно получить на сайтах различных клиник. Также существуют сайты, на которых врачи различных медицинских организаций предоставляют платные или бесплатные услуги по расшиоровке анализов и решают вопрос необходимости обращения к акушеру-гинекологу лично. Онлайн-консультации проводятся также по поводу ведения беременности, воспалитель- ных заболеваний органов малого таза и проблемам бесплодия [18-20].

В Нижегородской области в 2008 г. была разработана и внедрена информационная система мониторинга и курации беременных с момента постановки на учет до 42-го дня после родов, объединившая все женские консультации и роддома области. Эороективность ее внедрения выразилась, в частности, в положительной динамике показателя младенческой смертности, который за 5 лет использования системы снизился на 16,3\%. Потенциальный экономический эфрфект, рассчитанный по методике ВОЗ, составил 927,1 млн. рублей [21].

Аналогичная по задачам облачная автоматизированная система «Региональный акушерский мониторинг» была внедрена на территории Свердловской области. Она включала амбулаторные и стационарные этапы оказания медицинской помощи с дистанционным управлением и технологиями СППВР [22].

В большей части зарубежных статей указано то, что использовать ТМ более выгодно она снижает затраты на проезд до клиники, личное посещение, отсутствует необходимость пропускать рабочие дни [23].

Более узкие тематические статьи отражают эфроективность телемедицины и удовлетворенность пациентов в конкретных ситуациях - например, была показана средняя экономия в размере 14459 долл. США на одну беременность с использованием телемедицинских услуг [24, 25].

\section{- выноды}

Таким образом, анализируя состав публикаций в различных базах видно, что телемедицина в акушерстве и гинекологии является во многом нераскрытым направлением (доля таких публикаций по разным базам данных составляет всего 0,15\% - 0,26\% в общей телемедицинской тематике). Первые публикации по использованию TMT в акушерстве и гинекологии появились в середине 70-х годов XX века (по дистанционному образованию врачей акушеров-гинекологов еще в 60-х годах), однако на протяжении десятилетий подобные статьи оставались единичными.

Однако судя по динамике статей за последние 2 года (рост в 2019 г. к 2018 г. составил 
4,0 раза, в 2020 г. к 2019 г. - 1,69 раза), интерес научной общественности к этим направлениям растет. В частности, оказание акушерско-гинекологической помощи в условиях COVID-19 стало спусковым механизмом для разработки и внедрения новых технологий и приложений для проведения дистанционного консультирования. Принципиальное значение имеют статьи, материалы интернетконфреренций и другие фрормы публикаций об опыте реализации телемедицинских проектов в области акушерства и гинекологии в журналах и на сайтах ведущих фредеральных научных центров, что послужит методической базой для развития этого направления в регионах России.

Исходя из результатов анализа проведенных исследований стоит отметить, что при ис- пользовании ТМТ в ведении беременности с факторами риска, оказании медицинской помощи женщинам с гинекологической патологией, а также при проведении абортов количество осложнений не превышало показатели очного приема.

В России становится все больше медицинских учреждений, которые предлагают услуги онлайн, проводят профрессиональные конференции и описывают свой опыт применения дистанционных консультаций.

Применение ТМТ в акушерстве и гинекологии имеет хорошие перспективы, так как позволяет повысить доступность, качество и безопасность медицинской помощи, что особенно актуально в условиях пандемии COVID-19.

\section{ЛИTEPATYPA}

1. Паспорт фредерального проекта «Создание единого цифрового контура в здравоохранении на основе единой государственной инфрормационной системы в сфрере здравоохранения (ЕГИСЗ)» [Электронный pecypc]. URL: https://static3.rosminzdrav.ru/system/attachments/ attaches/000/046/712/original/FP_Cifrovoj_kontur_zdravooxraneniya.pdf?1 565344851] (Дата обращения: 28.04.2021). [Passport of the federal project «Sozdanie edinogo cifrovogo kontura v zdravoohranenii na osnove edinoj gosudarstvennoj edinoj gosudarstvennoj informacionnoj sistemy v sfere zdravoohraneniya (EGISZ)» [Electronic resource]. URL:https://static3.rosminzdrav.ru/system/attachments/attaches/000/046/712/original/FP_Cifrovoj _kontur_zdravooxraneniya.pdf?1565344851 (Accessed: 28.04.2021) In Russian)].

2. Terzi I. Didactic television in obstetrical and gynecological clinics. Italian. Minerva Ginecol 1955. Jan 15;7(1):1-4.

3. Howorka E, Kornacki Z. Die Aufgaben des klinischen Vortrages im geburtshilflich-gynäkologischen Unterricht und ihre Realisierung mit Hilfe des Fernsehens [The tasks of clinical lecture in obstetric-gynecological instruction and their realization by means of television]. Zentralbl Gynakol. German, 1966 Jan 8;88(1):9-13. PMID: 4166639.

4. Владзимирский А.В. Телемедицина: Curatio Sine Tempora et Distantia M., 2016; 663 c. [Vladzimirsky A.V. Telemedicine: Curatio Sine Tempora et Distantia. M., 2016;663 s. (In Russian)].

5. Володин Н.Н. Новые технологии в решении проблем перинатальной Медицины. Педиатрия 2004(3):56-60. [Volodin N.N. New technologies in solving problems of perinatal Medicine. Pediatriya $=$ Pediatria 2004(3):56-60. (In Russian)].

6. Царегородцев А.Д., Кобринский Б.А. Телемедицинские технологии для дистанционных консультаций и заочного повышения квалификации врачей. Российский вестник перинатологии и педиатрии 1999(5):6-10. [Tsaregorodtsev A.D., Kobrinsky B.A. Telemedicine technologies for remote consultations and correspondence training of doctors. Rossijskij vestnik perinatologii i pediatrii = Russian Bulletin of perinatology and pediatrics 1999(5):6-10. (In Russian)].

7. Ди Ренцо Д., Макацария А.Д., Цибизова В.И., Капанна Ф., Разеро Б., Комличенко Э.В. и др. 0 принципах работы перинатального стационара в условиях пандемии коронавируса. Вестник Российской Академии медицинских наук 2020;75(1):83-92. [Di Rentso D., Makatsariya A.D., Tsibizova V.I., Kapanna F., Razero B., Komlichenko E.V. i dr. On the principles of the perinatal hospital in the context of the coronavirus pandemic. Vestnik Rossijskoj Akademii medicinskih nauk = Annals of the Russian Academy of Medical Sciences 2020;75(1):83-92. (In Russian)].

8. Hoppe KK, Williams M, Thomas N, Zella JB, Drewry A, Kim K, Havighurst $\mathrm{T}$, Johnson HM. Telehealth with remote blood pressure monitoring for post- partum hypertension: A prospective single-cohort feasibility study. Pregnancy Hypertens 2019 Jan(15):171-176. PMID: 30825917; PMCID: PMC6681910. https://doi.org/10.1016/.jpreghy.2018.12.007.

9. Duarte SS, Nguyen TT, Koch C, Williams K, Murphy JD. Remote Obstetric Anesthesia: Leveraging Telemedicine to Improve Fetal and Maternal Outcomes. Telemed J. E. Health. 2020;26(8):967-972. https://doi.org/10.1089/tmj.2019.0174. PMID: 31710285.

10. Пырегов А.В., Холин А.М., Юрова М.В., Хамо А.А. Анализ эффрективности телемедицинских консультаций в акушерстве по профилю «Анестезиология и реаниматология» на примере двухлетнего опыта Национального исследовательского центра. Акушерство и гинекология 2020(1):155-162. [Pyregov A.V., Kholin A.M., Yurova M. V., Khamo A. A. Analysis of the effectiveness of telemedicine consultations in obstetrics in the profile «Anesthesiology and resuscitation» on the example of the twoyear experience of the National Research Center. Akusherstvo $i$ ginekologiya = Obstetrics and Gynecology 2020(1):155-162. (In Russian)]. 11. Чугунова Т.Н. Активный мониторинг состояния плода в условиях телемедицины - эффективная технология перинатального акушерства. Вопросы практической педиатрии 2008;3(5):55-57. [Chugunova T.N. Active monitoring of fetal health in telemedicine conditions-effective technology of perinatal obstetrics. Voprosy prakticheskoj pediatrii = Clinical Practice in Pediatrics 2008;3(5):55-57. (In Russian)].

12. Telemedicine for medical abortion: a systematic review. M. Endler, A. Lavelanet, A. Cleeve, B. Ganatra, R. Gomperts, K. Gemzell-Danielsson. An International Journal of Obstetrics \& Gynaecology 2019 Aug;126(9):1094-1102. [Электронный ресурс]. URL: https://www. ncbi.nlm.nih.gov/pmc/articles/PMC7496179/ (Accessed: 28.04.2021). https://doi.org/10.1111/1471-0528.15684.

13. Казанков 0. Использование телемедицины в гинекологии и перинатологии [Электронный ресурc]. URL: https://evercare.ru/oleg-kazankovispolzovanie-telemeditsiny-v-ginekol (Дата обращения: 01.12.2020). [Kazankov 0 . The use of telemedicine in gynecology and perinatology [Electronic resource]. URL: https://evercare.ru/oleg-kazankov-ispolzovanietelemeditsiny-V-ginekol (Accessed: 28.04.2021). (In Russian)].

14. Сидорова А.В., Смородина Е.А. Внедрение телемедицинских технологий в медицинских учреждениях Самарской области. Наука XXI века: актуальные направления развития 2020;1-2:623-627. [Sidorova A.V., Smorodina E. A. Introduction of telemedicine technologies in medical institutions of the Samara region. Nauka XXI veka: actual directions of development 2020;1-2:623-627. (In Russian)].

15. Сивов Е.В. Оценка диагностических возможностей дистанционного мониторирования состояния плода в динамике третьего триместра беременности. Авторефр. дис. к.м.н. Челябинск, 2013;21 с. [Sivov E.V. Eval- 
uation of diagnostic capabilities of remote monitoring of the fetal condition in the dynamics of the third trimester of pregnancy. Autoref. diss. Candidate of Medical Sciences Chelyabinsk, 2013;21 s. (In Russian)].

16. Балашов И.С. О методах сбора физиологических параметров для использования в системе поддержки данных принятия врачебных решений. В сб. Трудов XIX Международного конгресса «Цифровое здравоохранение». М., 2018;63-64 с. [Balashov I. S. About methods of collecting physiological parameters for use in the data support system for medical decision-making. In the collection of Proceedings of the XIX International Congress «Cifrovoe zdravoohranenie». M., 2018;63-64 p. (In Russian)].

17. Сухих Г.Т., Шувалова М.П., Шешко Е.Л., Швабский О.Р. Расширение границ возможностей в родовспоможении. Федеральный проект «Развитие сети Национальных медицинских исследовательских центров и внедрение инновационных медицинских технологий». Менеджмент качества в медицине 2019(4)36-39. [Sukhoi G.T., Shuvalova M.P., Sheshko E.L., Shvabsky O.R. Expanding the boundaries of opportunities in maternity care. Federal project 2»Development of the network of National medical research Centers and introduction of innovative medical technologies». Menedzhment kachestva $v$ medicine $=$ Quality management in medicine 2019(4)36-39. (In Russian)].

18. Сайт «Спроси врача» - онлайн консультация акушера-гинеколога [Электронный ресурc]. URL: https://sprosivracha.com/questions/ beremennost-i-rody (Дата обращения: 28.04.2021). [Website «Sprosi vracha» - on-line consultation of an obstetrician-gynecologist [Electronic resource]. URL: https://sprosivracha.com/questions/beremennost-i-rody (Accessed: 28.04.2021). (In Russian)].

19. Сайт АНО «Центр иммунологии и репродукции»- Интернетконсультация акушера-гинеколога, гинеколога-эндокринолога [Электронный ресурc]. URL: https://www.cironline.ru/services/3779 (Дата обращения: 28.04.2021). [Website of the ANO «Centr immunologii i reprodukcii» - Internet consultation of an obstetrician-gynecologist, gynecologist-endocrinologist [Electronic resource]. URL: https://www.

\section{Сведения об авторе:}

Леванов В.М. - д.м.н., профессор кафедры социальной медицины и организации здравоохранения ФГБОУ ВО «Приволжский исследовательский медицинский институт» Минздрава России, ведущий научный сотрудник лаборатории медицинской информатики и телемедицины ГНЦ РФ - «Институт медикобиологических проблем» РАН; Нижний Новгород, Москва, Россия; levanov53@rambler.ru; РИНЦ AuthorID: 562021

Перевезенцев Е.А. - к.м.н., доцент кафедры социальной медицины и организации здравоохранения ФГБОУ ВО «Приволжский исследовательский медицинский институт» Минздрава России; Нижний Новгород, Россия; peregal@yandex.ru; РИНЦ AuthorID: 661243

Калиткина О.А. - студентка ФГБОУ ВО «Приволжский исследовательский медицинский университет» Минздрава России; Нижний Новгород, Россия

\section{Вклад автора:}

Леванов В.М. - обработка данных, написание статьи, 34\% Перевезенцев Е.А. - разработка дизайна исследования, редактирование статьи, 33\%

Калиткина О.А. - поиск публикаций по теме исследования, обработка данных, 33\%

Коноликт интересов: Авторы заявляет об отсутствии конорликта интересов.

Финансирование: Статья написана без финансовой поддержки.

\section{Статья поступила: 22.03.21}

Принята к публикации: 30.04.21 cironline.ru/services/3779 (Accessed: 28.04.2021). (In Russian)]. 20. Сайт Медицинского центра «Гармония». Дистанционная консультация врача [Электронный ресурc]. URL: https://www.g-mc.ru/distancionnaya-konsultaciya-vracha (Дата обращения: 28.04.2021). [Website of the Media Center «Harmoniya». Remote consultation of a doctor [Electronic resource]. URL: https://www.g-mc.ru/distancionnaya (Accessed: 28.04.2021). (In Russian)].

21. Коновалов А.А. Научное обоснование совершенствования организации и управления информационным обеспечением здравоохранения региона (на примере Нижегородской области). Автореф. дисс. ... д.м.н. Нижний Новгород, 2014;47 с. [Konovalov A.A. Scientific justification for improving the organization and management of information support for healthcare in the region (on the example of the Nizhny Novgorod region). Autoref. for the competition ... Doctor of Medical Sciences Nizhny Novgorod, 2014;47 s. (In Russian)]

22. Зильбер Н.А., Анкудинов Н.О. Региональный акушерский мониторинг: инновационный инструмент управления кластером родовспоможения. Журнал телемедицины и электронного здравоохранения 2019;5(1):3-7. [Zilber N.A., Ankudinov N.0. Regional obstetric monitoring: an innovative tool for managing the cluster of obstetric care. Zhurnal telemediciny $i$ elektronnogo zdravoohraneniya = Russian Journal of Telemedicine and E-Health 2019;5:(1):3-7. (In Russian)].

23. Morrison J, Bergauer NK, Jacques D, Coleman SK, Stanziano GJ. Telemedicine: cost-effective management of high-risk pregnancy. Manag Care 2001 Nov;10(11):42-6,48-9. [Электронный ресурc]. URL: https://pubmed.ncbi.nlm.nih.gov/11761593.

24. Lanssens D, Thijs IM, Grieten L. Effectiveness of Telemonitoring in Obstetrics: Scoping Review. Journal of Medical Internet Research 2017;19(9):e327. https://doi.org/10.2196/jmir.7266.

25. Pflugeisen BM, Mou J. Patient Satisfaction with Virtual Obstetric Care. Matern Child Health J. 2017 Jul;21(7):1544-1551. https://doi.org/10.1007/s10995-017-2284-1.

\section{Information about author:}

Levanov V.M. - Dr. Sc., Professor of the Department of Social Medicine and Health Organization of the Privolzhsky Research Medical Institute of the Ministry of Health of Russia, Leading Researcher of the Laboratory of Medical Informatics and Telemedicine of the State Scientific Center of the Russian Federation - Institute of Biomedical Problems of the Russian Academy of Sciences; Nizhny Novgorod, Moscow, Russia;

levanov53@rambler.ru; https://orcid.org/0000-0002-4625-6840

Perevezentsev E.A. - PhD, Associate Professor of the Department of Social Medicine and Health Organization of the Federal State Budgetary Educational Institution of Higher Education «Privolzhsky Research Medical Institute» of the Ministry of Health of Russia; Nizhny Novgorod, Russia; peregal@yandex.ru; https://orcid.org/0000-0002-8537-6482

Kalitkina O.A. - student of the Volga Research Medical University of the Russian Ministry of Health; Nizhny Novgorod, Russia

\section{Author contributions:}

Levanov V.M. - data processing, article writing, 34\% Perevezentsev E.A. - research design development, article editing, 33\%

Kalitkina O.A. - search for publications on the topic of research, data processing, $33 \%$

Conflict of interest: The author declare no conflict of interest.

Financing: This article was written without financial support.

Received: 22.03.21

Accepted for publication: 30.04.21 

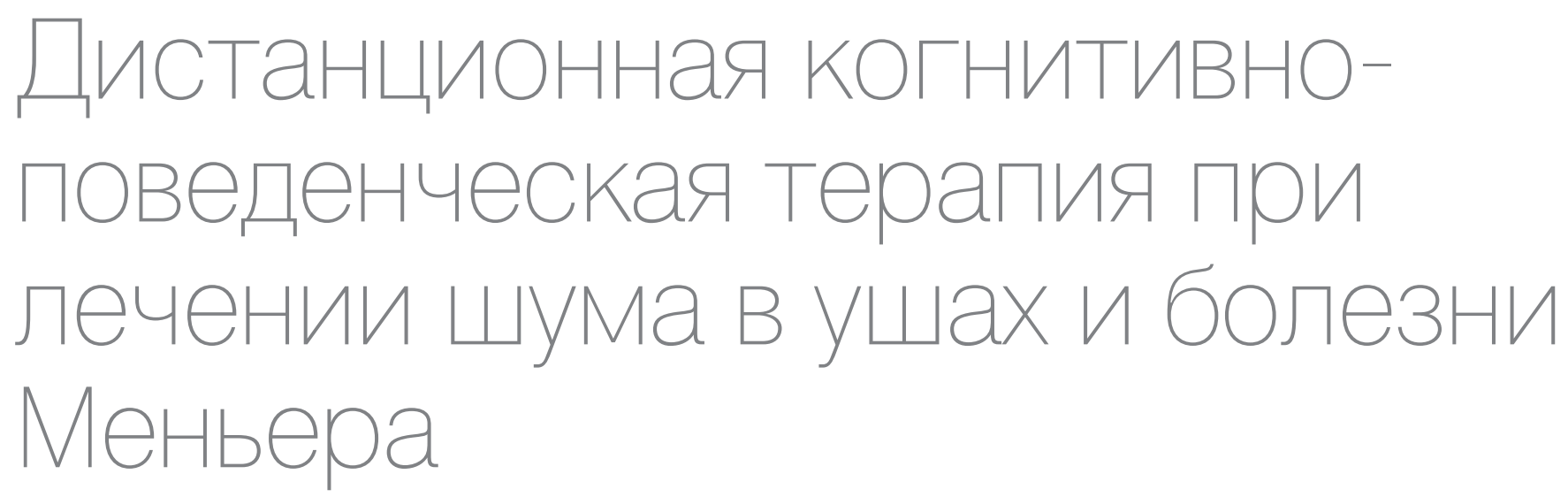

\section{Литературный обзор}

\section{А.И. Мелехин}

НОЧУ ВО «Гуманитарный институт имени П.А. Столыпина»; д.57, ул. Поляны, Москва, 117042, Россия

Контакт: Мелехин Алексей Игоревич, clinmelehin@yandex.ru

\section{Аннотация:}

Ведение. Телемедицина при шуме в ушах и болезни Меньера может быть реализована на различных этапах: диагностика, первоначальная клинико-психологическая оценка, долгосрочное наблюдение и онлайн-поддержка, протоколы когнитивно-поведенческой терапии с поддержкой виртуальной реальности и мобильных приложений.

Материалы и методы. Проведен поиск, анализ и систематизация литературы по базам PubMed, e-library и Google Scholar по ключевым словам «когнитивно-поведенческая терапия», «болезнь Меньера», «мониторинг», «тиннитус», «соgnitive-behavioral therapy», «Meniere's disease», «monitoring», «tinnitus» - всего 117 источников, из которых для написания статьи были отобраны 16. Из анализа были исключены диссертации и их авторефераты, а также тезисы конференций.

Результаты. В статье описана структура, специфика, формы и эффрективность применения протоколов дистанционной когнитивно-поведенческой терапии в аудио-вестибулярной реабилитации на примере хронического тиннитуса (шума в ушах), гиперакузии и болезни Меньера. Выделены психические френотипы пациентов с тиннитусом, что позволяет выстроить персонализированных подход к лечению, снижающий риски развития рефрактерного течения. Систематизированы имеющиеся в зарубежной практике психотерапевтические стратегии, применяемые при лечении тиннитуса. Представлена тактика дистанционного клинико-психологического обследования пациентов с тиннитусом для выделения психотерапевтических мишеней.

Выводы. Когнитивно-поведенческая терапия (КПТ) показала умеренный эффрект для уменьшения раздражения и стресса, вызванного шумом у данных пациентов. Дистанционные протоколы когнитивно-поведенческой терапии на данный момент рассматриваются как «альтернатива» очной форме лечения.

Ключевые слова: тиннитус; шум в ушах; болезнь меньера; когнитивно-поведенческая терапия; психотерапия; гиперакузия.

Для цитирования: Мелехин А.И. Применение дистанционной когнитивно-поведенческой терапии при лечении шума в ушах и болезни Меньера. Российский журнал телемедицины и электронного здравоохранения 2021;7(2):31-43; https://doi.org/10.29188/2712-9217-2021-7-2-31-43

\section{Remote cognitive behavioral therapy for tinnitus and Meniere's disease Literature review}

https://doi.org/10.29188/2712-9217-2021-7-2-31-43

\section{A.I. Melekhin}

Humanitarian Institute named after P.A. Stolypin; 57, st. Polyany, Moscow, 117042, Russia

Contact: Alexey I. Melekhin, clinmelehin@yandex.ru

\section{Summary:}

Introduction. Telemedicine for tinnitus and Meniere's disease can be implemented at various stages: diagnosis, initial clinical and psychological assessment, long-term follow-up and online support, cognitive-behavioral therapy protocols with support for virtual reality and mobile applications. 
Material and methods. A search, analysis and systematization of literature was carried out in the PubMed, e-library and Google Scholar databases using the keywords "cognitive-behavioral therapy», "Meniere's disease», "monitoring", «tinnitus» - a total of 117 sources, of which for writing the article were selected 16. Theses and their abstracts, as well as conference abstracts were excluded from the analysis.

Results. The article describes the structure, specificity, forms and effectiveness of the use of distance cognitive-behavioral therapy protocols in audio-vestibular rehabilitation using the example of chronic tinnitus (tinnitus), hyperacusis and Meniere's disease. The mental phenotypes of patients with tinnitus are highlighted, which makes it possible to build a personalized approach to treatment that reduces the risks of developing a refractory course. The psychotherapeutic strategies used in the treatment of tinnitus are systematized. The tactics of remote clinical and psychological examination of patients with tinnitus to identify psychotherapeutic targets are presented.

Conclusions. Cognitive behavioral therapy (CBT) has been shown to be moderately effective in reducing noise-induced irritation and stress in these patients. Distance learning CBT protocols are currently being viewed as an «alternative» to face-to-face treatment.

Key words: tinnitus; noise in ears; Menier's disease; cognitive behavioral therapy; psychotherapy; hyperacusis.

For citation: Melekhin A.I. Remote cognitive behavioral therapy for tinnitus and Meniere's disease. Russian Journal of Telemedicine and E-Health 2021;7(2):31-43; https://doi.org/10.29188/2712-9217-2021-7-2-31-43

\section{В ВВЕДЕНИЕ}

За последние несколько лет в зарубежной отоларингологической практике происходит активное развитие аудио-вестибулярной когнитивно-поведенческой реабилитации (audiologistdelivered cognitive-behavioral therapy, specialized CBT treatment for tinnitus) для пациентов с шумом в ушах (тиннитус), гиперакузией, мизофонией в связи с их неоднозначным, сензитивным ответом на фрармакологическое лечение (антидепрессанты, антиконвульсанты), наличием серьезных побочных эфрфектов, зависимости от бензодиазепинов и отсутствия эфрфективности от биомедицинских методов лечения (экстракт гинкгобилоба) [1]. Показано, что большинство врачей общей практики и ЛОР-специалистов (>60\%) по сей день недовольны текущими тактиками лечения [2]. По сей день для многих специалистов тиннитус (хронический шум в ушах) как и такое длительное прогрессирующее заболевание поражающее внутреннее ухо как болезнь Меньера (Menire's disease) представляют собой сложный вызов [2]. Данная болезнь характеризуется рецидивирующими приступами головокружения, шаткостью, головной болью по типу «каски неврастеника», различными шумами в ушах (чаще, писк) с болезненным восприятием звуков (голоса, бытовые звуки). Головокружение и шум в ушах - самые дезориентирующие симптомы, которые негативно влияют на многие аспекты повседневной жизни пациента: качество сна (трудности засыпания, ночные частые пробуждения), фон настроение, концентрацию внимания. Все это приводит к развитию у пациента спектра из- бегающего, перестраховочного и сканирующеприслушивающего («есть или нет звука») поведения. Например, пациенты предупреждают свое окружение чтобы громко не разговаривали, избегают шумные места (торговые центры, кинотеатры, кафе), постоянно пользуются берушами или слуховыми аппаратами с режимом маскировки.

Говоря про тиннитус, то данное расстройство (или точнее скажем симптом в структуре какого-то состояния), представляет собой одну из самых распространенных и тревожных отологических проблем и определяется как фантомное восприятие звука без соответствующего акустического или механического коррелята в улитке. Встречается примерно у 10-15\% населения, может быть изолированным расстройством и протекать в структуре Болезни Меньера [3]. Этиология данных расстройств по сей день не изучена, однако ряд исследований показывает влияние психических фракторов. К сожалению, меньшинству пациентов помогает только медицинские стратегии, например, медикаментозный, хирургический подход, диета, ЛФК, массаж и др. Это связано с неоднородной природой тиннитуса, о чем свидетельствует целый спектр особенностей восприятия и реакций на эти звуки у пациентов. Для некоторых пациентов шум в ушах не является единственным, изолированным симптомом, поскольку он сочетается с различными состояниями, включая генерализованное тревожное расстройство, состояние эмоционального выгорания, переживание утраты (например, потеря отца, или перенесенный аборт), нарушения сна чувствительность к звукам (осо- 
бенно к голосам) и снижение когнитивных фрункций $[2,4]$. Эти изменчивость усложняет тактику построения лечения, особенно в современных сложившихся условиях. Обнаружено, что в общей популяции этих пациентов пандемия COVID-19 способствовала усилению состояния гипервозбуждения, повысила уровень тревоги, привела к ухудшению шума в ушах: головокружения, нарушений сна, риска суициидальности. Также следует учитывать, что одним из нейротропных проявлений перенесенного SARS-CoV-2 являются такие коронавирус-ассоциированные отоневрологические симптомы (coronavirus-related otoneurological symptoms) как тиннитус и головокружение, причина возникновения которых по сей день не известна [5].

Сложности анатомической локализации тиннитуса, патофизиологии, а также хронологический разрыв между инициацией и триггерами указывают на то, что тиннитус проявляется уникальными у каждого пациента расстройством. Помимо этого, существует проблема лечения резистентного тиннитуса (resistant tinnitus) у пациента [2].

Когнитивно-поведенческая терапия (КПТ) показала умеренный эфорект для уменьшения раздражения и стресса, вызванного шумом у данных пациентов [3]. Однако многие люди, страдающие тиннитусом, не имеют доступа к КПТ, потому что ее распространение в России часто ограничивается отсутствием мест для лечения, специалистов, владеющих протоколами лечения [4]. Интересно отметить, что КПТ редко предлагается пациентам с шумом в ушах в США (менее $1 \%$ ), отчасти из-за отсутствия квалифицированных специалистов, которые владеют протоколами лечения. Кроме того, многие пациенты не решаются обращаться за психологической помощью, потому что они связывают шум в ушах с соматическими, а не психологическими причинами и поэтому считают психотерапию неуместной [6].

Дистанционные протоколы когнитивно-поведенческой терапии (guided CBT-based internet intervention, ICBT) на данный момент рассматриваются как «альтернатива» очной фрорме по нескольким причинам [3, 7]:

- Гибкость, эфорективность по времени и затратам;

- Доступность обращения к ведущим специалистам в данной области для прохождения обследования, консультации и психотерапии;

- Из-за своего довольно технического-регламентного фрормата дистанционные протоколы могут восприниматься как менее «психологиче- ские». Легче воспринимают пациенты, которые рассматривают свое заболевание через линзу что оно «соматическое»;

- Пациенты с тиннитусом часто обладают рядом коммуникативных барьеров, искаженной внутренней картиной болезни и здоровья, предпочитают анонимность, они хотят избежать предполагаемой стигматизации, которой часто опасаются при очном посещении специалиста.

В связи с этим целью данной статьи является познакомить специалистов в области психического здоровья, неврологии и отоларингологии с протоколами, и эфффективностью дистанционной когнитивно-поведенческой терапии тиннитуса, гиперакузии и болезни Меньера.

\section{ПСИХИЧЕСКИЕ ФЕНОТИПВ|} ПАИМЕНTOE C TMHHMTYCOM

Гетерогенное проявление шума в ушах указывает на то, что существуют определенные подгруппы пациентов (рис. 1), которые требуют индивидуальной тактики лечения.

Показано, что полученные при обследовании пациента определенные показатели по индексу функционального статуса при тиннитусе (TFI) указывают на необходимость психотерапевтического вмешательства (например, баллы выше 25) в комплексном лечении шума в ушах. Пациенты, у которых тиннитус протекает в структуре депрессии, работы горя при применении определенных протоколов психотерапии показывают улучшения в симптомах, но они не так мотивированы на улучшение состояния, и вовлеченность в лечение как группа пациентов с высоким тиннитус-дистрессом (TFI>25). Ранее сообщалось о подобных результатах, поскольку вовлеченность в психотерапию у пациентов с депрессией (32\%) ниже, чем у людей с тревогой (78\%) [2]. Это может указывать на то, что группе пациентов с депрессией потребуется больше директивной, регламентной психотерапевтической поддержки. Таким образом каждой группе пациентов (рис.1) требуется свой индивидуальный протокол психотерапевтической помощи, определенный формат проведения психотерапии изза наличия ряда барьеров, особенностей психического здоровья [8]. На данный момент считается, что при тиннитусе терапевтические стратегии, должны быть в основном сосредоточены состояние системы противовозбуждения (лимбическая система, вегетативная система, гипоталамо-гипофризарно-надпочечниковая ось). 
Применение неврологической тактики с помощью глубокой стимуляции мозга, транскраниальной магнитной стимуляции не увенчались успехом [2].

\section{- ПСИХOTEPATEВTИЧECRИЕ СТPАTЕГИИ ПР⿴囗лЕЧЕНИИ ТМНHМTУСА}

На данный момент тактика психотерапевтическая лечения данных расстройств проводиться специально обученным клиническим психологом с помощью ряд стратегий, представленных нами на рис. 2

В ряде исследований в отличии от психодинамического, когнитивно-поведенческий подход показал свою эфорективность по снижению тяжести шума в ушах. Кроме того, было показано, что когнитивно-поведенческая терапия умень- шает эфффекты целого ряда дополнительный состояний у данных пациентов, таких как гиперакузия, бессонница, тревога, депрессия и сторонние болевые проявления (например, МФБС, лицевую боль) [2, 6]. Результаты очного лечения оставались стабильными от 2 до 12 месяцев. Это практический психотерапевтический подход, ориентированный на решение конкретных беспокоящих симптомов у пациента, направленный на изменение бесполезных паттернов мышления и поведения, чтобы способствовать изменению порога чувствительности к звуку в ушах и умению управлять различными формами головокружения [3]. При болезни Меньера основное внимание уделяется поведенческому управлению функций вестибулярной системы поддержания равновесия и взора, минимизация избегающего поведения, и в том числе агорафобии [9]. Благодаря своей доказанной эфффективности КПТ

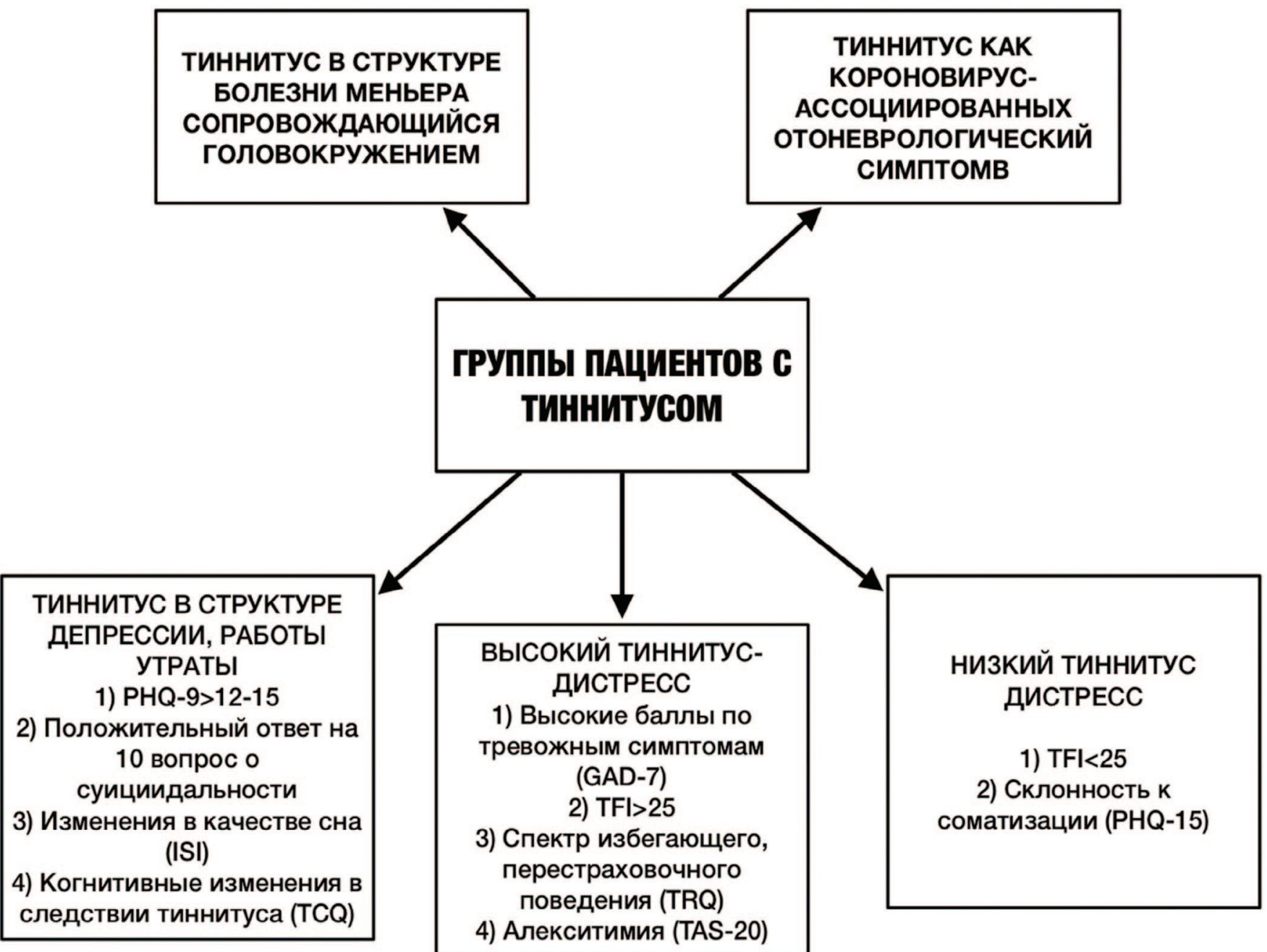

Рис. 1. Разделение пациентов с тиннитусом в зависимости от психологических особенностей.

Примечание. PHQ - Patient Health Questionnaire, ISI - Insomnia Severity Index, TCQ - Tinnitus Cognitions Questionnaire, GAD-7 - General Anxiety Disorder-7; THI - Tinnitus Functional Index; THQ - Tinnitus Handicap Questionnaire; TAS-20 - Toronto Alexithymia Scale

Fig. 1. Patients with tinnitus depending on psychological characteristics.

Note. PHQ - Patient Health Questionnaire, ISI - Insomnia Severity Index, TCQ - Tinnitus Cognitions Questionnaire, GAD-7 - General Anxiety Disorder-7; THI - Tinnitus Functional Index; THQ - Tinnitus Handicap Questionnaire; TAS-20 - Toronto Alexithymia Scale 
рекомендуется в многочисленных клинических рекомендациях по тиннитусу и болезни Меньера по всему миру [3]. Также учитывая разделение нами пациентов с тиннитусом в зависимости от психологических особенностей (рис. 1), под каждое течение можно составить персонализированный протокол КПТ с учетом потребностей пациента. Когда мы выше говорили про положительные стороны дистанционных форматов КПТ, то следует также отменить, что в исследованиях применения психотерапии для минимизации симптомов тиннитуса и головокружения, было показано, что отсев варьировался от 20 до 51\%. Когда пациентов спрашивали о причине отсева, они часто указывают в качестве основной причины практические проблемы, такие как нехватка времени, фринансовая составляющая, неграмотный специалист, территориальный барьеры, пандемия со страхом заразиться [10]. Это действительно так как «очные» протоколы КПТ (faceto-face CBT) представляется как всеобъемлющее, многомерное 8-недельное вмешательство, ресурсы и затраты на проведение вмешательства могут быть непомерно высокими. Терапия КПТ состоит из различных 15-25 компонентов, в связи с этим начали разрабатываться дистанционные протоколы КПТ (Web/Internet - based cognitive behavioral therapy) включающие "

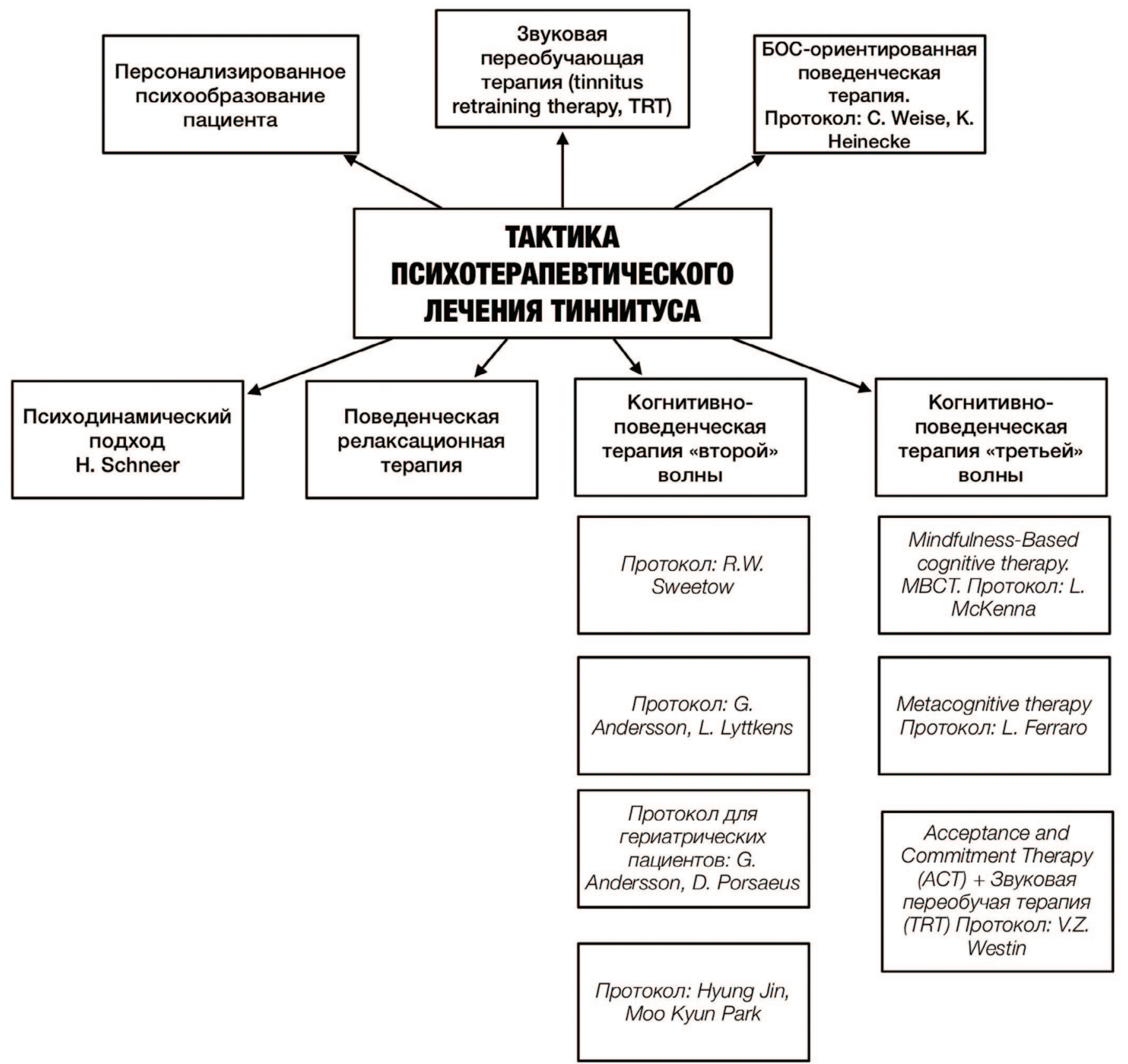


модули применения виртуальной реальности от отработки поведенческих навыков (Virtual Reality-Enhanced Behavioral Therapies), а также специальных мобильных приложений [6].

Имеющиеся ряд исследований показали идентичную эфорективность дистанционных протоколов наряду с очными по снижению тиннитус дистресса, симптомов тревоги, депрессии у пациентов, повышения психического благополучия. Ремиссия от 3 до 18 месяцев. Было показано, что дистанционные протоколы в 2-3 раза эорорективнее для специалиста в плане охвата лечения пациентов. Дополнительно проводятся исследования по эффрективности дистанционных протоколов КПТ по снижению гипермобилизации при тиннитусе (relaxation-based Internet-based cognitive behavioral therapy, R-ICBT) (рис. 3) [11-15].

\section{фОРМЬІ И РЕХКИМЬІ} ПРОВЕДЕНИЯ ДИСТАНИИОННОЙ
КОГНИТИВНО-ПОВЕДЕНЧЕСКОЙ
ТЕРАПИИ В АУДИО-
ВЕСТИБУЛЯРНОЙ РЕАБИЛИТАИИИ

- Поэтапные, «управляемые» специалистом протоколы КПТ (stepped-care approach, therapist-guided ICBT) имеют фриксированное время лечения, которое составляет от 10 до 12 недель, и это, вероятно, создает эфорект «крайнего срока», мотивирующий как пациента, так и специалиста двигаться вперед. Терапия проводиться с помощью skype, zoom, whatsapp с видео с определенным регламентом. Протокол состоит из прохождения совместно с пациентом отдельных 22 модулей, каждый из которых сосредоточен на конкретной проблемной области и методах ее решения. Например, повышение устойчивости к шуму, пребывание в тишине, снижение декатастрооизации [3]. Модули сопровождаются пояснительными видеороликами, еженедельными домашними заданиями, протоколами и диагностическими шкалами.

- «Автоматизированные», самоуправляемые, низкоинтенсивные протоколы КПТ (СВТ self-help approaches, Low-intensity ICВT) Включает полный пакет психотерапии, но без интерактивного планирования домашних заданий, регистрации и отчетности. Пациентам предлагается прочитать наиболее подходящие модули и попробовать описанные в них методы. Это может быть с помощью сайта, брошюры-самопомощи. Дополнительно используется приложения для телефона ReSound Tinnitus Relief, когда пациента просят применять 1) габбитуацию, т.е. слушать искусственно созданный звук, максимально похожий на тот, который он слышит. В среднем 60 мин в день; 2) частичную маскировку благоприятным звуком. Также пациентам сообщают, что они должны прочитать и опробовать полученный материал по психотерапии в

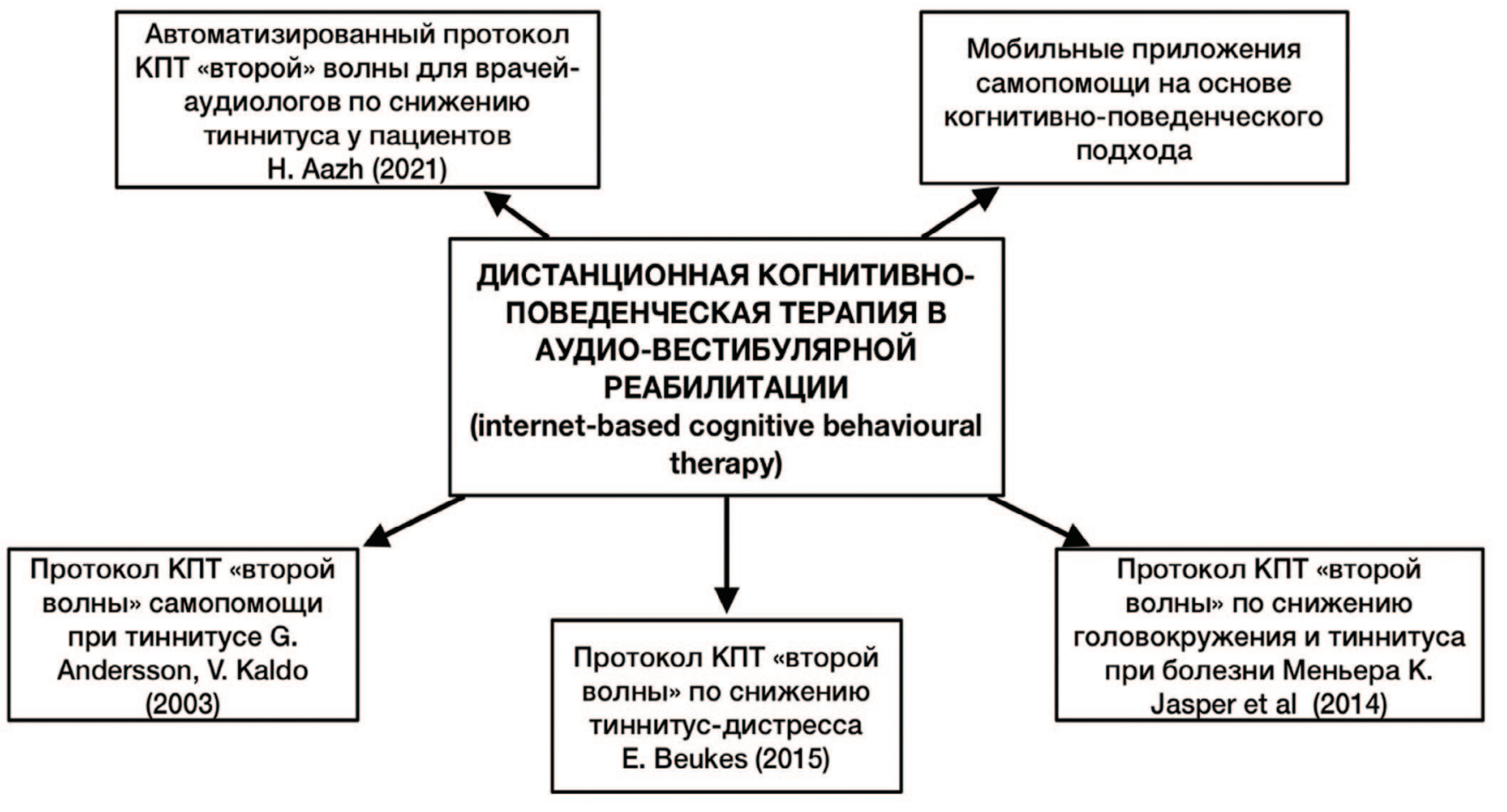

Рис. 3. Протоколы дистанционной когнитивно-поведенческой терапии, применяющиеся в аудио-вестибулярной реабилитации Fig. 3. Protocols of remote cognitive-behavioral therapy used in audio-vestibular rehabilitation 
течение трех месяцев, а затем они заполнят дополнительные диагностические шкалы, получат обратную связь от специалиста. У пациентов каждые 1-2 недели есть возможность связаться со специалистом через электронную почту, чтобы задать вопросы по лечению. Однако специалист не ведет активного, сопровождающего наблюдения за пациентами и не контактирует с ними. Динамику лечения он может отслеживать по полученным шкалам. Распространенным зарубежным протоколом является интернет или онлайн фрорма КПТ (www.icbt4tinnitus.com) по снижению тиннитус дистресса, состоящий из семи онлайн-модулей (табл. 1) [1].

Данный протокол также предлагается врачам-аудиологам в качестве дополнительного психотерапевтического лечения или в качестве самостоятельного лечения, если никакое другое вмешательство не требуется. Эфорективность данного протокола по сей день находиться на стадии исследования [1].

Говоря про режимы проведения КПТ, то она может быть 1) в структуре комплексного лечения с применением формакотерапии, которая в последствии будет снижаться; 2) только применения КПТ без какой-то фрармакологической опоры [6].

\section{- ТАКТИКА ДИСТАНЦИОННОГО КЛИНИКО-ПСИХОЛОГИЧЕСКОГО ОБСЛЕДОВАНИЯ ПАЦИЕНТОВ С ТИННИТУСОМ}

Одна из проблем при работе с людьми, страдающими тиннитусом, - это обычно наблюдаемая диссоциация между «объективной» медицинской реальностью и психологической, воспринимаемой реальностью пациента. Во многих случаях тиннитус, носит характер соматофрормной этиологии, кроме случаев шумовой травмы или общего старения слуховой системы в анамнезе. Однако без надлежащих инструментов для объективной оценки такого явления отоларингологам может быть сложно быстро идентиорицировать этих пациентов, которых следует обследовать, чтобы избежать нежелательных исходов, таких как самоповреждающее поведение и самоубийство. Например, мы рекомендуем в обследование пациентов с аудио-вестибулярными изменения включать оценку удовлетворенности качеством жизни (например, EuroQol EQ-5D-5L) помогающая выявить наиболее «уязвимых» пациентов, тех кого нужно будет обследовать и оказать приоритетную психотерапевтическую помощь [8].

Таблица 1. Общие модули интернет, автоматизированной формы когнитивно-поведенческой терапии тиннитус дистресса $X$. Аша и соавт.

Table 1. General modules of the internet, an automated form of cognitive behavioral therapy for tinnitus distress

Общие модули / Common modules

Психологический скрининг

Психообразование пациента о тиннитусе.

Введение в КПТ при тиннитусе

Поведенческие эксперименты при тиннитусе для снижения, избегающего/ перестраховочного поведения

\section{Onиeatue / Description}

Пациенту отправляются диагностические шкалы, направленные на оценку симптомов тревоги, депрессии, тиннитус-дистресса, изменений в качестве жизни и сна. Результаты высылают на адрес электронной почты пациента. В отчет включаются рекомендации (по необходимости) для дальнейшего медицинского обследования, дополнительного психологического обследования.

В этом модуле пациенты узнают о КПТ и ее значении для лечения тиннитуса. Выгоды и издержки.

Этот модуль дает возможность исследовать и оспаривать негативные мысли у пациента, связанные с тиннитусом, путем тестирования различных форм поведения. Это призвано помочь пациенту выяснить, оправданы ли его негативные мысли и прогнозы относительно шума в ушах. Большинство пациентов заявляют, что по крайней мере некоторые из их прогнозов не сбываются и их мысли — это когнитивный мусор. Это первый шаг, который поможет им изменить свои негативные мысли. Минимизация поведения «лечения в аптеке» или «поиска альтернативного лечения» (doctor-shopping).

В этом модуле пациенты узнают об общих фрормах когнитивных искажений, с помощью специалиста развивают навыки выявления ошибок суждения в их собственном восприятии тиннитуса.

Объединение различных когнитивных и поведенческих техник, которым они научились, для выявления негативных автоматических мыслей и борьбы с ними, а также для противодействия им контрутверждениями (глубинным убеждениям о собственной уязвимости).

Идея этого модуля состоит в том, чтобы использовать силу позитивной психологии для генерирования оптимизма, который важен для улучшения психического здоровья, за счет психологической гибкости.

Модуль заключительной оценки помогает 1) установить прогресс, достигнутый каждым пациентом в управлении тиннитусом, и 2) повысить их уверенность и мотивацию в использовании навыков КПТ для управления тиннитусом. 


\section{- Аудиологическое обследование пациента} Применяется дистанционная аудиометрия (Selftest Internet-based audiometry) для чистого тона от 500 до 8000 Гц или для более сложных стимулов, таких как проверка распознавания речи при шуме. Также видео отоскопия (рис. 4). Онлайн-аудиометрический скрининг может проводиться самостоятельно, экономя время и затраты для системы здравоохранения, но полный аудиометрический анализ все равно потребует врача-аудиолога;

- Нарушение сна оценивается с помощью индекса тяжести бессонницы (The Insomnia Severity Index, ISI), который представляет собой краткую анкету из пяти пунктов (от 0 до 4 баллов), оценивающую продолжительность сна, качество сна и негативные дневные симптомы. Дополнительно для к данному индексу пациенту задается вопрос про изменение чувствительности к звуку перед сном и лежа в кровати, который оценивается от 1 - не выше, чем у других людей до 5 баллов - чрезмерно;
- Тиннитус дистресс оценивается (на выбор) с помощью Tinnitus Reaction Questionnaire (TRQ), Mini-Tinnitus-Questionnaire (Mini-TQ) или Tinnitus Handicap Inventory (THI). Изменения в оценках по шкале ТНІ связаны с симптомами депрессии (шкалы BDI и HADS-D), рисками суицидальных идей и/или самоповреждающего поведения, нарушениями сна (ISI);

- Функциональное состояния при тиннитусе оценивается с помощью Tinnitus Functional Index (TFI). Данная шкала касается таких аспектов влияние тиннитуса, как концентрация, проблемы со сном, ограничение социальных контактов из-за шума в ушах и др. (рис. 5).

В ходе КПТ мы делаем акцент на изменениях в показателе чувство контроля (рис. 5) над тиннитусом, так как он является важным прогностическим фрактором психического благополучия. Для пациентов с тиннитусом особенно полезно иметь инструмент, с помощью которого они могут легко избавиться от хронического и

\section{ТЕЛЕМЕДИЦИНСКИЙ СКРИНИНГ}

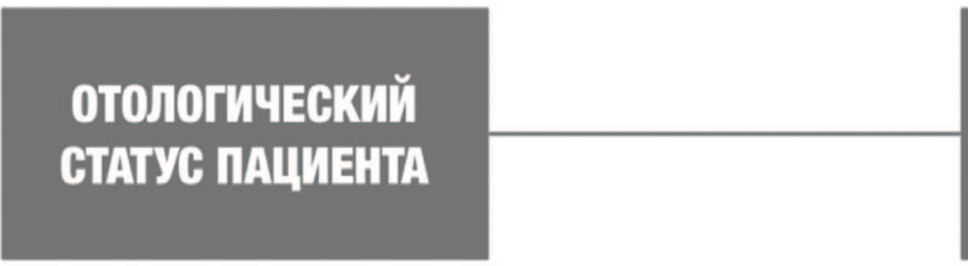

ПСИХОЛОГИЧЕСКОЕ ФУНКЦИОНИРОВАНИЕ ПАЦИЕНТТ
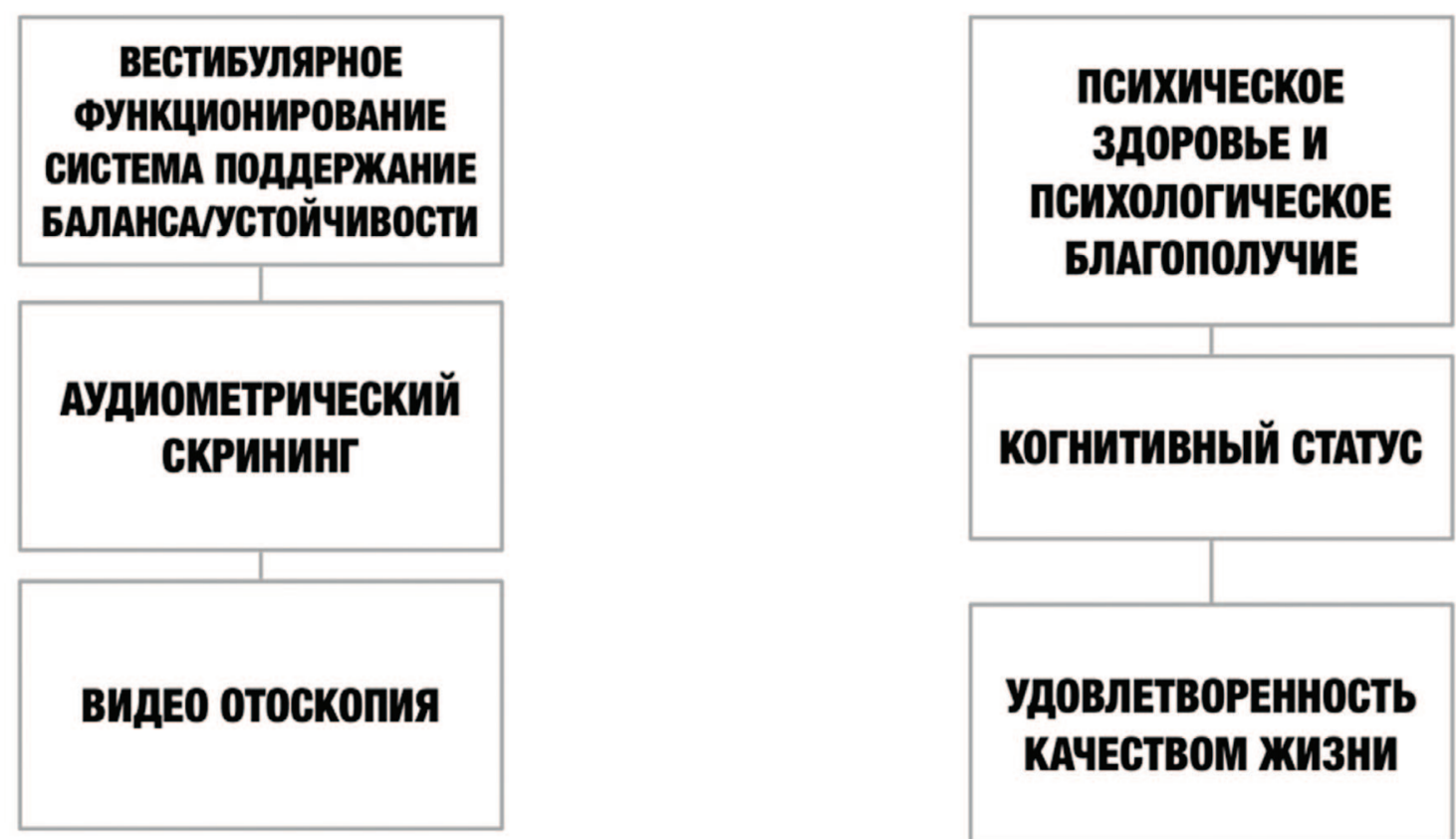

Рис 4. Специфика и кпючевые элементы телемедицинского скрининга в аудио-вестибулярной когнитивно-поведенческой реабилитации Fig. 4. Specifics and key elements of telemedicine screening in audio-vestibular cognitive-behavioral rehabilitation 
неприятного дискомфрорта. Контроль шума в ушах с помощью внешних и внутренних стратегий влияет на самоутверждение и улучшает психологическое фрункционирование пациента;

- Когнитивный дефицит при тиннитусе выражается в изменениях компонентов исполнительных функций (например, контроле внимания). Для оценки склонности к совершению когнитивных промахов и ошибок при выполнении повседневных задач, таких как сбои в восприятии, памяти и двигательных функциях мы рекомендуем применять шкалу Cognitive Failures Questionnaire (CFQ);

- Наличие и степень выраженности тревоги оценивается с помощью General Anxiety Disorder-7 (GAD-7), депрессии (Patient Health Questionnaire, PHQ-9), соматизации (Patient Health Questionnaire-15, PHQ-15);

- Наличие и степень выраженности гиперакузии - Hyperacusis Questionnaire (HQ);

- Наличие дисфункциональных когнитивно-поведенческих схем

Young Schema Questionnaire (YSQ-S3). Haпример, у пациентов с болезнью Меньера наблюдаются высокие показатели по «самопожертвованию», «негативизму/пессимизму», «жестким стандартам», «поиску одобрения», «привилегированности», «уязвимости», «подавления эмоций». При тиннитусе у пациентов преобладают «жесткие стандарты», «поиск одобрения», «привилегированность», «пунитивность».

\section{П ПРОтокоЛ КПт ДЛЯ} ПАИМЕНТОВ С БОЛЕЗНВIO МЕНВЕРА К. ХАГНЕБО И СОАВТ.

Данный психотерапевтический протокол К. Ханбело и соавтр. направлен на 1) снижение избегающего поведения пациента [9]. Минимизацию страха выходить из дома. Например, пациенты с болезнью Меньера не выходят из дома без сопровождения кого-то из близких. Избегают определенных телесных движений, например, подниматься по лестнице, убираться. 2) Снижение неуверенность и боязни приступов головокружения; 3) Минимизации гиперчувствительности (катастрофизации) к звуку.

Общие стратегии, которые применяются в рамках протокола:

- Техники на снижение соматического (мышечного) гипервозбуждения, деперсонализации.

- Тренировка стабилизации для облегчения симптомов головокружения с помощью поведенческих экспериментов. С разделением «истинного» головокружения и ощущения головокружения в структуре реакции паники.

- Систематическая десенсибилизация, провоцирующая тревожные для пациента ситуации (например, пребывание в тишине), чтобы уменьшить избегающее и перестраховочное поведение, в том числе и поисковое поведение.

- Реструктуризация негативных мыслей пациента и маркировок («а вдруг», «а если опять...»,

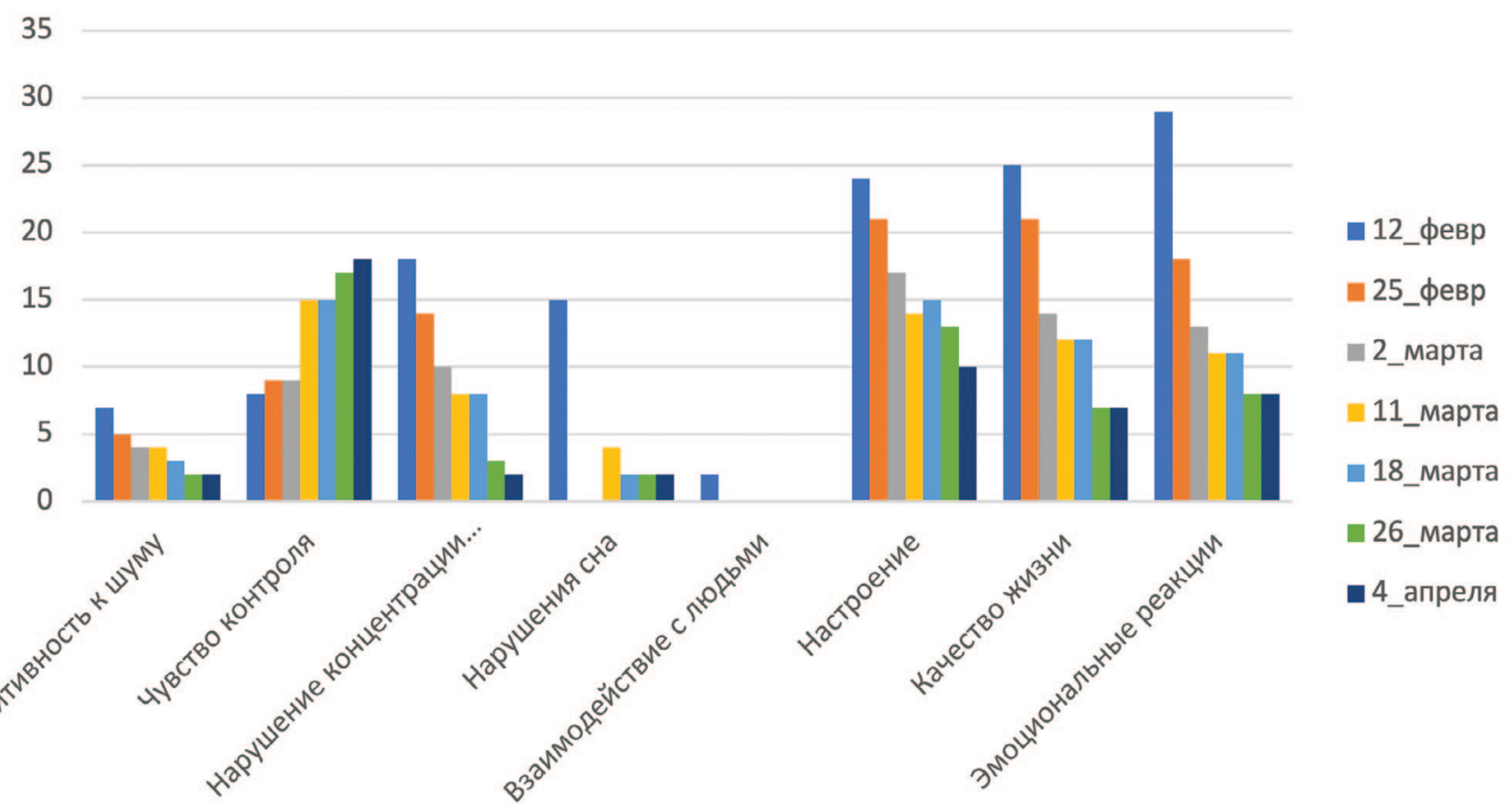

Рис. 5. Изменение показателей индекса функционального статуса при тиннитусе (ТНІ) у пациента 38 лет с генерализованным тревожным расстройством после перенесенного коронавируса в ходе дистанционной когнитивно-поведенческой терапии

Fig. 5. Changes in the indicators of the functional status index in tinnitus (THI) in a 38-year-old patient with generalized anxiety disorder after suffering from coronavirus during remote cognitive behavioral therapy 
«опять он») и убеждений «это мое наказание... все бесполезно», «буду страдать и нужно постоянно с этим бороться».

- Постановка поведенческих задач для повышения поведенческой активности, чтобы уменьшить чувство безнадежности, опустошенности, уязвленности.

- Определение конкретных целей для усиления телесного осознания, чтобы получить чувство контроля, минимизировать страх, неопределенность от течения болезни.

Регламент сессий 50-60 минут, проводиться в формате видеосвязи с специалистом (skype, zoom, whatsapp с видео). 1 сессия каждые 5-9 дней. Каждые 4 дня специалисту на электронную почту пациент отправляет фрунциональный дневник проявлений тиннитуса и головокружения.
Эорфрективность. Применение данного протокола в комплексной терапии способствует снижению головокружения как истинного в структуре болезнь Меньера, так и в структуре тревожных проявлений. Снизился шум в ушах и симптомы депрессии. Ремиссия наблюдалась на протяжении года [9].

\section{- ПРОТОКОЛ ДИСТАНИИОННОЙ кOГНИТМЕНО-ПОВЕДЕНЧЕСКОЙ ТЕРАПИИ ТИННИТУС-ДИСТРЕССА Е. БЕЙKЕС И COAВT.}

В основе данного протокола лежит первоначально разработанная 22 модульная программа дКПТ, разработанная Дж. Андерссоном и его коллегами [16]. Основное внимание в ней уделяется оризическим, эмоциональным и проблемным послед-

Таблица 2. Описание и специфика сессий протокола дистанционной Кпт для пациентов с болезнью Меньера К. Хагнебо и соавт.

Table 2. Description and specifics of remote CBT protocol sessions for patients with Meniere's disease

Сессия / Session

1

3 (две недели спустя)

4 (две недели спустя)

5 (две недели спустя)

6 (неделю спустя)

7 (неделю спустя)

8 (три недели спустя)

9 (две недели спустя) бустерная сессия

10 (через 2-4 месяца)
Опиеание, өпецифика, домашние задания / Description, specifics, homework

- Обучение релаксационным техникам снятия гипервозбуждения (Progressive Muscle Relaxation Long version).

- Психообразование с акцентом на внутреннюю картину болезни и здоровья пациента с целью улучшить понимание болезни Меньера

Связь тревоги и страха с физическими симптомами болезни Меньера.

- Установление психотерапевтического кадра (скайп или zoom-консультации) и установление терапевтического альянса.

Домашнее задание: применение релаксационных техник дважды в день (утро и перед сном), а также во время возникновения беспокоящих симптомов. Вести дневник тиннитус-проявлений и приступов головокружения в какие моменты они возникают.

- Разбор дневника приступов тиннитуса и головокружения.

- Обучение техникам снижения сканирования ощущения в собственном теле и маркировки их как угрожающих.

- Когнитивная перестройка негативных мыслей, связанных со способностью пациента справляться с болезнью Меньера.

Домашнее задание: применение техник релаксация (без предварительного напряжения мышц) два раза в день.

- Разбор дневника приступов тиннитуса и головокружения. Трудностей при выполнения релаксационных упражнений.

- Обнаружение «рискованных» ситуаций и поведения, связанных с возникновением головокружения, избегание тишины. Применение функционального анализа дисфункционального поведения пациента.

- Закрепление навыков условного расслабления и быстрого расслабления фризического гипервозбуждения.

• Применение техники «быстрого» мышечного расслабления при головокружении (Brief version of PMR/2-min version), a также при первых приступах предчувствия симптомов и при ощущениях тревоги, «ухода в себя».

- Поведенческий план по снижению чувствительности к тревожным ситуациям.

- Функциональная тренировка по стабилизации равновесия: обучение пациента пристально смотреть на стабильный объект.

Домашнее задание состояло из продолжения

обучение релаксации и постановка поведенческих задач по снижению избегающего, перестраховочного поведения. Первое что мы рекомендуем делать пациентам это короткие прогулки сначала с опорой потом без, далее расширять.

- Экспозиционная терапия, направленная на снижение избегающего поведения. Например, посещение торгового центра, прогулок, поход по лестнице, пребывание в тихом помещении.

- Составление поведенческого плана продвигаться к следующим избегающим пациентом ситуации. Например, пациент боится пойти к офтальмологу, т.к. последний приступ головокружения был у врача на приеме.

- Проведение поведенческого эксперимента.

- Разбор проведенного поведенческого эксперимента. Закрепление техники снятия маркировок со сканирования ощущения в теле.

- Разбор трудностей при выполнении релаксационных техник и техники фиксации при головокружении.

- Повышение осведомленности и телесных сенсациях, и способах их восприятия, селективного контроля.

- Поведенческий план снижения тревоги и головокружения

- Создание копинг-карточки самопомощи

- Поведенческий план снижения тревоги и головокружения

- Создание копинг-карточки самопомощи

- Против рецидивного плана.

• Система напоминания выполнять техники при головокружении, тревоги, появлении шума в ушах

• Разбор трудностей при выполнении техник. Наличие беспокоящих проявлений. Социальное функционирование.

• Оценка динамики состояния, наличия трудностей при выполнении когнитивных и поведенческих техник. 
Общие модули

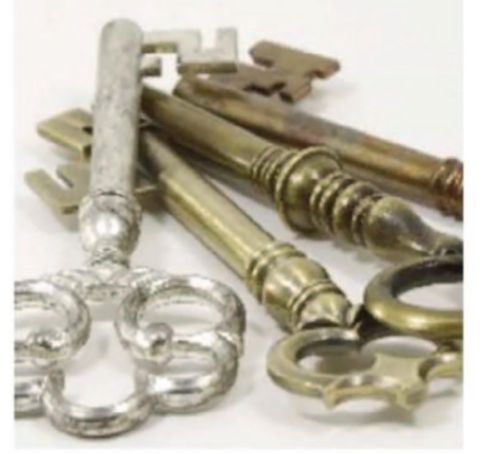

1. Обсуждение результатов психологического обследования. Мишени терапии и тактика

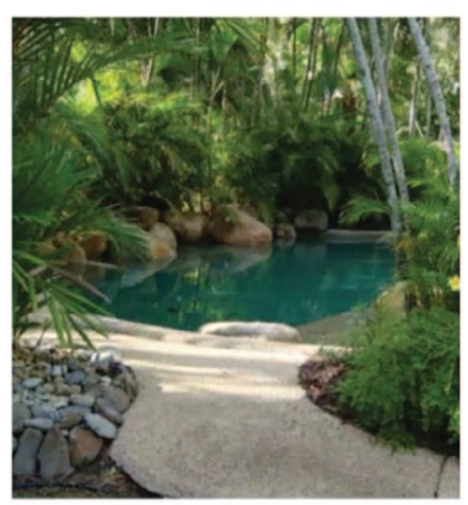

3. Обучение техникам снижения физического (мышечного) гипервозбуждения

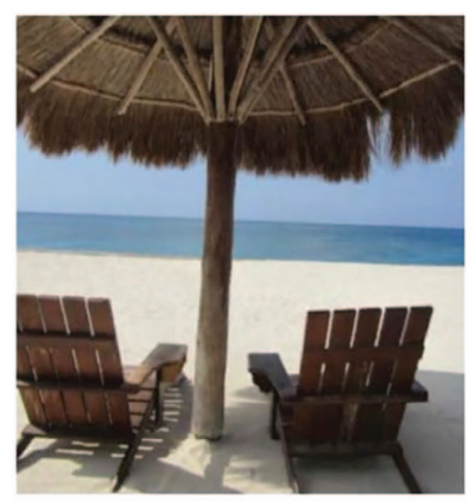

5. Обучение техникам снижения эмоционального гипервозбуждения за счет минимизации избегающего/перестрахово чного поведения,

а также сканирования ощущений.

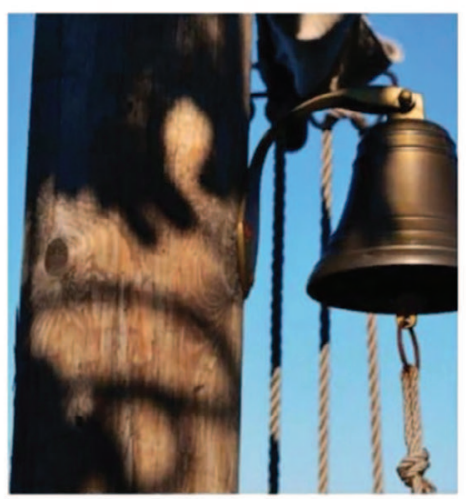

2. Психообразование о тиннитусе. Составление индивидуальной когнитивноповеденческой модели порочного круга тиннитусдистресса пациента.

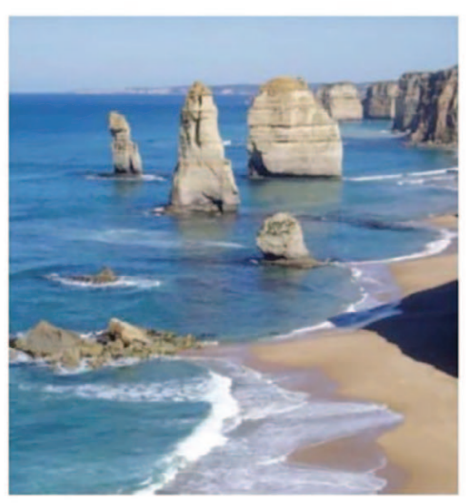

4. Техники формирования позитивных образов, «КОГнИТИВНЫЙ СТОП» и парадоксальная интенция в ответ на шум

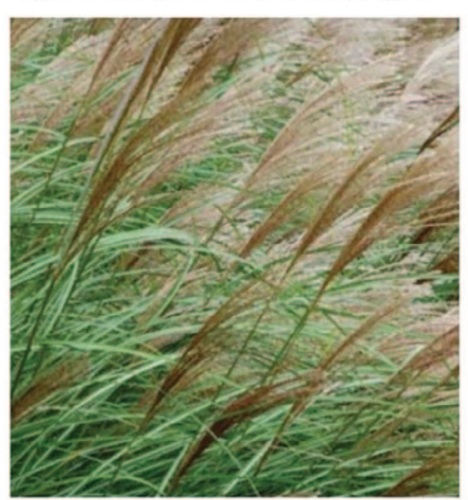

6. Алгоритм де-катастрофизации

\section{Дополнительные модули}

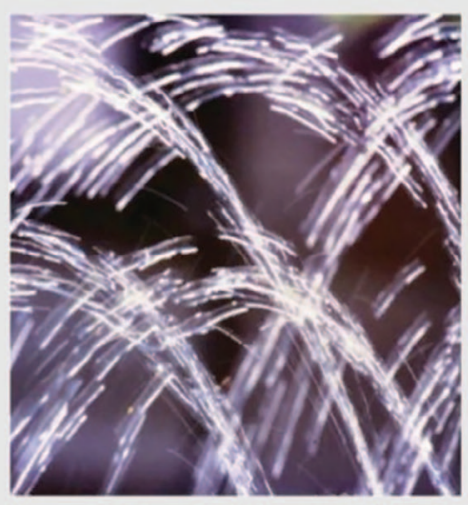

1. Техники направлены на снижение порогов чувствительности.

Частичные маскировки.

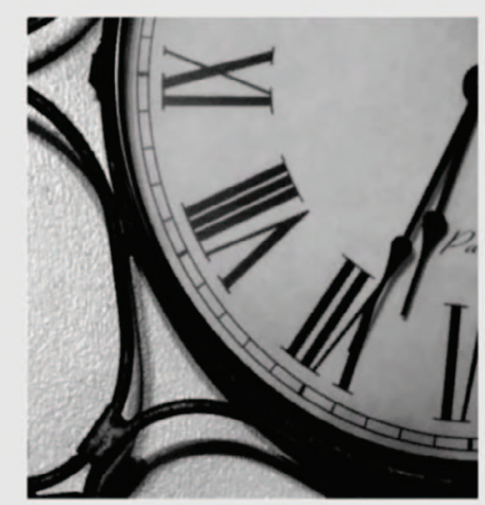

2. Техники направленные на снижение

хронической бессонницы (трудностей засыпания)

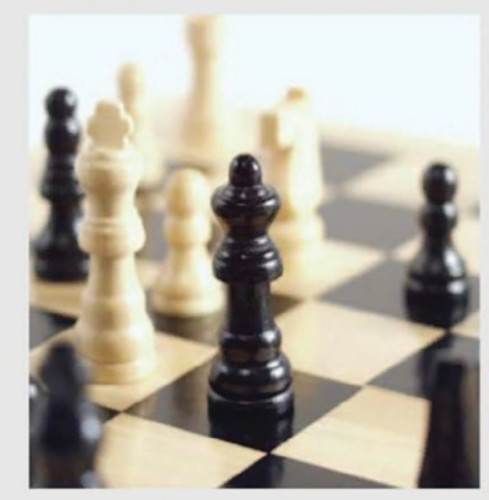

3. Техники формирования когнитивного фильтра для минимизации когнитивных нарушений

Рис. 6. Модули дистанционного протокола когнитивно-поведенческой терапии тиннитуса В. Елдри и соавт.

Fig. 6. Modules of the remote protocol of cognitive behavioral therapy of tinnitus 
ствиям ощущения шума в ушах, чтобы помочь привыкнуть к звуку в ушах, снизить порог чувствительности. В программу также включены ключевые аудиологические принципы, такие как использование обогащения звука [11-13]. Протокол частично адаптирован к индивидуальным психологическим особенностям пациентов и состоит из 16 модулей и 5 дополнительных модулей (рис. 6 и в табл. 3).

Модули пациенты совместно со специалистом проходят еженедельно в течение 8 недель. Пациентов инструктируют о том, как взаимодействовать с модулями, а затем практиковать предлагаемые методы на ежедневной основе. Таким образом, программа носит всеобъемлющий характер и предлагает ряд ключевых аспектов КПТ для максимального изменения поведения и когнитивных реакций на шум в ушах. Информацию можно прочитать онлайн, загрузить для чтения в автономном режиме или распечатать. Модули содержат смесь инорормации, видео, викторин, диаграмм, предлагаемых технологий для применения в повседневной жизни, рабочих листов самопомощи для отслеживания прогресса и решений общих проблем.
Эорфективность. Наблюдались значительные улучшения функционального статуса (TFI), симптомов бессонницы (ISI), тревоги (GAD-7) и депрессии (PHQ-9), когнитивных изменений (CFQ), гиперакузии (HQ) и удовлетворенности качеством жизни (SLS). Ремиссия наблюдалась на протяжении 2 месяцев. Улучшения наблюдались через 4 недели после психотерапии. Уровень отсева составил 30 $35 \%$. На данный момент проводятся исследования по дальнейшей контролируемой оценке эфорективности данного лечения по сравнению с очными протоколами КПТ [14].

\section{ВЬШВОДЬ}

- Телемедицина при шуме в ушах и болезни Меньера может быть реализована на различных этапах: диагностика, первоначальная клинико-психологическая оценка, долгосрочное наблюдение и онлайн-поддержка, протоколы когнитивно-поведенческой терапии с поддержкой виртуальной реальности и мобильных приложений. Каждый из этих этапов (скрининг, диагностика, психотерапевтическое лечение и долгосрочное наблюдение) яв-

Таблица 3. Структура и описание модулей дистанционного протокола когнитивно-поведенческой терапии тиннитус-дистресса В. Елдри и соавт.

Table 3. Structure and description of modules of the remote protocol of cognitive behavioral therapy for tinnitus distress

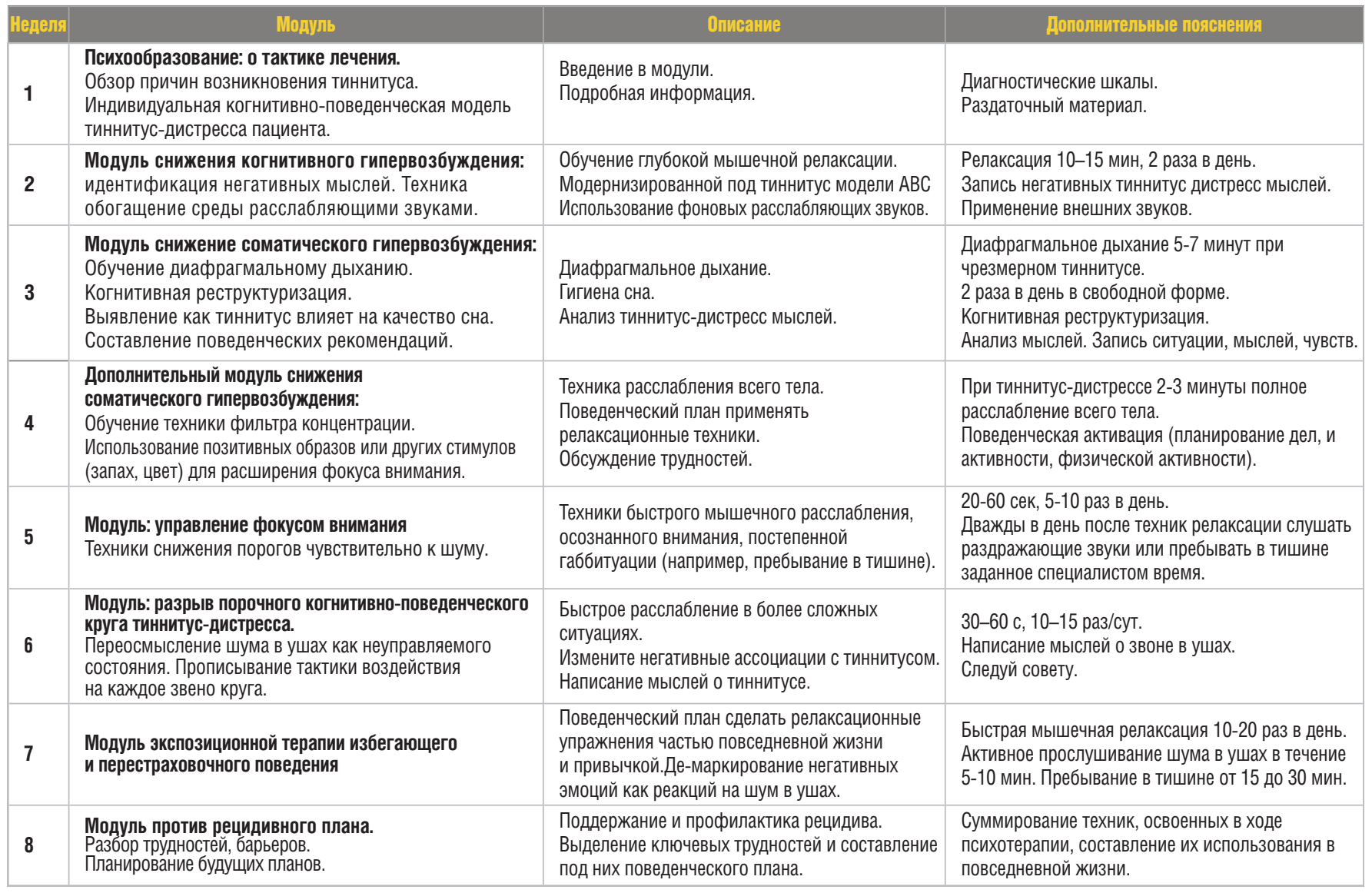


ляется независимым и часто требует различных специалистов (аудиологов, отоларингологов, неврологов, клинических психологов).

- Когнитивно-поведенческая терапия обладает наибольшей эороективностью в снижении шума в ушах, но редко применяется в клинической практике в России. Имеются убедительные данные, подтверждающие эффрективность КПТ для облегчения тиннитус-дистресса, головокружения при болезни Меньера, гиперакузии. Может быть эфффективной как очной, так и дистанционной форме независимо от того, проводится ли она клиническими психологами или специально обученными врачами-аудиологами.

- Пациенты с тиннитусом и болезнью Меньера которые проходят дистанционные протоколы когни- тивно-поведенческой терапии, оценивают ее эфрфективность 65-70\%, отмечают у себя большую уверенность в контроле симптомов, снижение катастрофизирующего стиля мышления, снижения прислушивания8 к шуму, улучшение качества сна. Эфоректы оставались стабильными от 2 до 9 месяцев.

- В клинической практике могут быть использованы различные фрорматы проведения дистанционной КПТ: 1) Поэтапные, «управляемые» специалистом протоколы; 2) «Автоматизированные», самоуправляемые, низкоинтенсивные протоколы КПТ, которые могут быть использованы для пациентов с более низким уровнем тиннитус-дистресса или с трудностями или низкой мотивацией к участию в лечении.

\section{ЛVTE}

1. Aazh H. Internet-based Cognitive Behavioral Therapy for Tinnitus: Insights from Health Care Professionals. The Hearing Journal 2021;74(2):20-29; https://doi.ogr/10.1097/01.HJ.0000734220.13107.55.

2. Han B.I., Lee, H.W. Tinnitus Update. Journal of clinical neurology (Seoul, Korea) 2021;17(1):1-10; https://doi.org/10.3988/jcn.2021.17.1.1.

3. Cognitive Behavioral Therapy for Tinnitus. Ed. Eldre W Beukes, Gerhard Andersson. Plural Publishing Inc. 2020;195 p.

4. Мелёхин А.И. Тактика лечения звона в ушах (тиннитуса) с точки зрения клинического психолога, Экспериментальная и клиническая оториноларингология 2021;5(2):66-79. [Melehin A.I. Tactics of treatment of tinnitus (tinnitus) from the point of view of a clinical psychologist. Experimental and clinical otorhinolaryngology 2021;5(2):66-79. (In Russian)].

5. Viola P., Ralli M., Pisani D. et al. Tinnitus and equilibrium disorders in COVID-19 patients: preliminary results. Eur Arch Otorhinolaryngol 2020;2(1):19-38; https://doi.org/10.1007/s00405-020-06440-7.

6. Aazh H., Landgrebe M., Danesh A. A. Cognitive Behavioral Therapy For Alleviating The Distress Caused By Tinnitus, Hyperacusis And Misophonia: Current Perspectives. Psychology research and behavior management 2019(12):991-1002. https://doi.org/10.2147/PRBM.S179138. 7. Heinrich S., Rozental A., Carlbring P. Treating tinnitus distress via the Internet: A mixed methods approach of what makes patients seek help and stay motivated during Internet-based cognitive behavior therapy. Internet Interv 2016(4):120-130. https://doi.org/10.1016/j.invent.2016.04.001.

8. Мелёхин А. И. Тактика лечения звона в ушах (тиннитуса) с точки зрения клинического психолога. Экспериментальная и клиническая оториноларингология 2021;5(2):66-79. [Melehin A. I. Tactics of treatment of tinnitus (tinnitus) from the point of view of a clinical psychologist. Experimental and clinical otorhinolaryngology 2021;5(2):66-79. (In Russian)].

9. Hagnebo C., Melin L., Hans Christian Larsen Cognitive-behavioural
Treatment of a Patient Suffering from Meniere's Disease. Scandinavian Journal of Behaviour Therapy 1998;27(1):42-48. https://doi.org/10.1080/02845719808408493.

10. Kaldo-Sandstrљm V., Larsen H.C., Andersson G. Internetbased cognitive-behavioral self-help treatment of tinnitus: clinical effectiveness and predictors of outcome. Am J Audiol 2004;13(2):185-92. https://doi.org/10.1044/1059-0889(2004/023).

11. Beukes E.W., Baguley D.M. Guided Internet-based versus face-to-face clinical care in the management of tinnitus: study protocol for a multi-centre randomised controlled trial. Trials 2017;18(1):186. https://doi.org/10.1186/s13063-017-1931-6.

12. Beukes E.W., Baguley D.M. Audiologist-Guided Internet-Based Cognitive Behavior Therapy for Adults With Tinnitus in the United Kingdom: A Randomized Controlled Trial. Ear Hear 2018;39(3):423-433. https://doi.org/10.1097/AUD.0000000000000505.

13. Beukes E.W., Manchaiah V. Internet-based cognitive behavioural therapy for adults with tinnitus in the UK: study protocol for a randomised controlled trial. BMJ Open 2015;5(1):19-34. https://doi.org/10.1136/bmjopen-2015008241.

14. Beukes E.W. Dismantling internet-based cognitive behavioral therapy for tinnitus. The contribution of applied relaxation: A randomized controlled trial. Internet Interventions 2021;25(1):38-41.

15. Beukes E.W., Manchaiah V., Allen P.M. Internet-Based Interventions for Adults With Hearing Loss, Tinnitus, and Vestibular Disorders: A Systematic Review and Meta-Analysis. Trends Hear 2019;23(2):17-49. https://doi.org/10.1177/2331216519851749.

16. Andersson G., Kaldo V. Cognitive-behavioral therapy with applied relaxation. In: Tyler RS, editor. Tinnitus treatment: clinical protocols. New York, NY: Thieme 2006;96-115.

\section{Сведения об авторах:}

А.И. Мелёхин - кандидат психологических наук, доцент, клинический психолог высшей квалификационной категории, психоаналитик, сомнолог, когнитивно-поведенческий терапевт НОЧУ ВО «Гуманитарный институт имени П.А. Столыпина»; Москва, Россия; clinmelehin@yandex.ru; РИНЦ AuthorID 6982-1468

\section{Вклад автора:}

А.И. Мелёхин - определение актуальных научных аспектов, обзор литературы, написание текста, 100\%

Конфрликт интересов: Автор заявляет об отсутствии конфликта интересов.

Финансирование: Исследование проведено без спонсорской поддержки.

Статья поступила: 29.04.21

Принята к публикации: 27.05.21

Information about authors:

Melekhin A.I. - PhD in Psychology, associate Professor, clinical psychologist of the highest qualification category, psychologist, psychotherapist, somnologist, cognitive behavioral psychotherapist. Humanitarian Institute named after P.A. Stolypin. Moscow, Russia, clinmelehin@yandex.ru, https://orcid.org/0000-0001-5633-7639

\section{Author Contribution:}

Melekhin A.I.- identification of relevant scientific aspects, literature review, text writing, 100\%

Conflict of interest. The author declare no conflict of interest.

Financing. The study was performed without external funding.

Received: 29.04.21

Accepted for publication: 27.05.21 


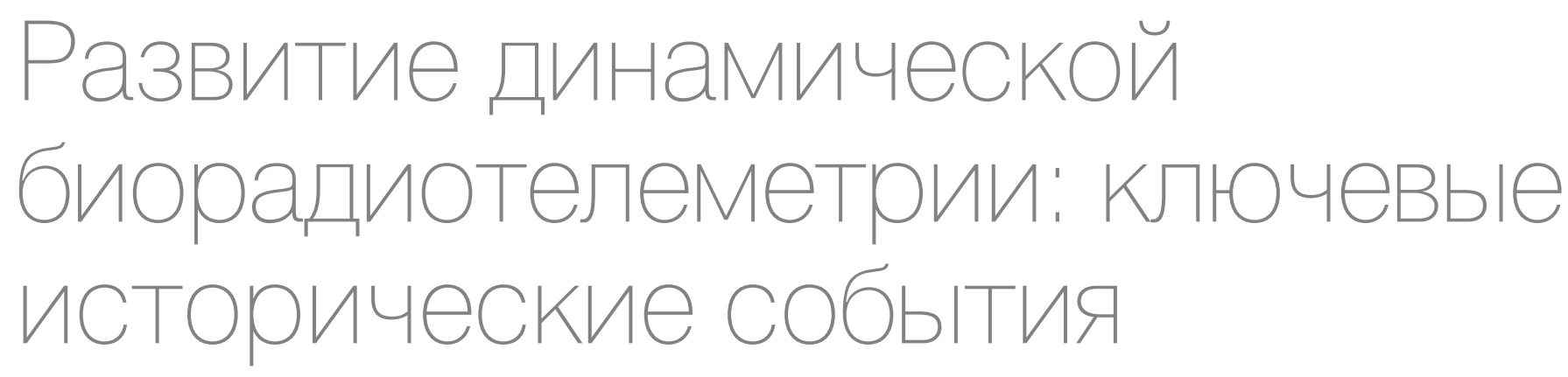

\section{Литературньй обзор}

\section{А.В. Владзимирский}

ГБУЗ «Научно-практический клинический центр диагностики и телемедицинских технологий Департамента здравоохранения Москвы»; д. 24, стр. 1, ул. Петровка, Москва, 127051, Россия

Контакт: Владзимирский Антон Вячеславович, a.vladzimirsky@npcmr.ru

\section{Аннотация:}

Ведение. Интенсивное развитие медицинской науки в XX веке потребовало разработки принципиально новых подходов и методов оценки функций организма в условиях различных видов деятельности. Это привело к появлению динамической биорадиотелеметрии.

Цель. Изучить основные этапы формирования динамической биорадиотелеметрии, охарактеризовав роль и вклад отдельных личностей и коллективов.

Материал и методы. Исследование базируется на эволюционном подходе, использованы методы анализа, синтеза, систематизации, а также проблемно-хронологический метод исторического познания.

Результаты. Первая система для телеметрии биологических данных по радио предложена А.А. Ющенко и Л.А. Чернавкиным в 1932 году. Система была успешно апробирована в экспериментальной ффизиологии. Комплексное развитие технологий и методологии биотелеметрии осуществлено в 1960-1970-х гг. группой под руководством В.В. Розенблата. Сорормирована «триада» научных задач, ставшая методологической основой научных исследований в сорере биотелеметрии. В ходе сотен исследований, выполненных с применением биорадиотелеметрии, в сфере нормальной и патологической физиологии накоплен огромный массив новой информации. Методы динамической биотелеметрии группы В.В. Розенблата получили широкое распространение во всем мире.

Выводы. Наибольшее значение биорадиотелеметрия имела для программ освоения космического пространства, фризиологических исследований спортсменов, а также для медицины труда. Благодаря этой технологии сорормировались новые направления знаний. Представлены два ключевых исторических этапа создания технологий и методологий динамической биорадиотелеметрии.

Ключевые слова: история телемедицины; биорадиотелеметрия; Свердловская биотелеметрическая группа; телемониторинг; телемедицинские технологии.

Для цитирования: Владзимирский А.В. Развитие динамической биорадиотелеметрии: ключевые исторические события. Российский журнал телемедицины и электронного здравоохранения 2021;7(2):44-49; https://doi.org/10.29188/2712-9217-2021-7-2-44-49

\section{Evolution of dynamic bioradiotelemetry: key historical events}

\section{Literature review}

https://doi.org/10.29188/2712-9217-2021-7-2-44-49

\section{A.V. Vladzymyrskyy}

Research and Practical Clinical Center of Diagnostics and Telemedicine Technologies, Department of Health Care of Moscow, Petrovka st., 24 b.1, 127051, Moscow, Russia

Contact: Anton V.Vladzymyrskyy, a.vladzimirsky@npcmr.ru

\section{Summary:}

Introduction. The intensive development of medical science in the XX century required the development of fundamentally new approaches and methods for assessing body functions during free movements and various activities. This led to the emergence of dynamic biotelemetry via radio.

Objective. To study the main points of the dynamic biotelemetry formation, characterizing the role and contribution of individuals and groups.

Material and methods. The research are based on an evolutionary approach; methods of analysis, synthesis, systematization, as well as the problem-chronological method of historical knowledge are used. 
Results. The first system of biotelemetry via radio proposed by A.A. Yushchenko and L.A. Chernavkin in 1932. The system has been successfully tested in experimental physiology. Comprehensive development of technologies and methodology of biotelemetry was carried out in the 1960-1970s by group led by V.V. Rosenblat. A classic "triad" of research objectives was form. The "triad" became the methodological basis of scientific research in the field of biotelemetry. In the course of hundreds researches (carried out using biotelemetry) in the field of normal and pathological physiology, a huge amount of new information has been accumulated. Methods of dynamic biotelemetry of V.V. Rosenblat are widely distributed throughout the world.

Conclusions. Biotelemetry was very important for space exploration programs, physiological studies of athletes, as well as for occupational medicine. Thanks to this technology, new directions of knowledge have been form. Two key historical events that led to the development of biotelemetry happened in 1930-1932 and 1960-1970 years.

Key words: history of telemedicine; biotelemetry; Sverdlovsk biotelemetry group; telemonitoring; telemedicine technologies.

For citation: Vladzymyrskyy A.V. Evolution of dynamic bioradiotelemetry: key historical events.

Russian Journal of Telemedicine and E-Health 2021;7(2):44-49; https://doi.org/10.29188/2712-9217-2021-7-2-44-49

\section{$B B=R_{1}=H M E$}

Динамическая биорадиотелеметрия - способ фриксации и оценки фризиологических параметров свободно двигающегося биологического объекта, который имеет значение для клинической практики (например, фрункциональные пробы, контроль при реабилитации) и медицинской науки. В настоящее время технологии и методологии динамической биорадиотелеметрии наиболее широко применяются в дистанционном контроле состояния здоровья (телемониторинге), космической и военной медицине $[1,2,3]$. Представляет интерес систематизация истории развития этого направления, причем в общем контексте эволюции телемедицины.

Цель. Изучить основные этапы фрормирования динамической биорадиотелеметрии, охарактеризовав роль и вклад отдельных личностей и коллективов.

\section{МАТЕРИАЛЬ| И МЕТОДЫ|}

В исследовании мы базировались на эволюционном подходе, использовали общие методы анализа, синтеза, систематизации, а также проблемнохронологический метод исторического познания.

Использованы литературные источники электронных библиотек «РИНЦ eLibrary», «Pubmed», a также каталог Российской государственной библиотеки. Подробная библиография представлена в авторской монографрии [4].

\section{РЕЗУЛЬТАТЬ}

В 1967 году руководитель лаборатории функциональной диагностики Свердловского научно-исследовательского института гигиены труда и профзаболеваний Владимир Викторович Розенблат произнес слова, которые вполне могут стать эпиграфом данной статьи: «Оценивая состояние тренированности спортсмена на врачебном... приеме, кому из нас не доводилось мечтать о наблюдении хотя бы за частотой пульса непосредственно во время упражнений на стадионе?» [3]. Действительно, к первой половине XX века фризиология, как и вся медицинская наука в целом, была хорошо осведомлена о функционировании организма человека до и после любых видов деятельности - спортивных упражнений, фризического или умственного труда, клинических функциональных проб, плавания под водой, управления самолетом и т.д. Но абсолютной загадкой оставалось, как работает организм во время такой активной деятельности.

Перед медицинским приборостроением была поставлена задача по созданию способов дистанционного контроля фризиологических параметров у свободно перемещающегося человека в процессе произвольной деятельности. Причем такой контроль должен быть неинвазивным и совершенно не отягощающим для обследуемого.

Несомненно, для медицинской науки первой половины прошлого столетия это был вызов. С одной стороны, в научной среде бытовало мнение об отсутствии значимости изучения фризиологических параметров во время активной деятельности. С другой - полностью отсутствовали технологии необременительной фриксации параметров у свободно движущегося (бегающего, прыгающего, работающего в горячем цеху и т.д.) объекта.

Первый в мире шаг для решения указанных проблем был сделан в 1930 году молодыми сотрудниками Института психоневрологии Коммунистической академии (г. Москва) фризиологом Александром Александровичем Ющенко и инженером-конструктором 
Леонидом Алексеевичем Чернавкиным. А.А. Ющенко родился в 1898 году, после получения высшего образования работал в лаборатории академика И.П. Павлова (Физиологический институт АН СССР); в конце 1920-х гг. - в лаборатории условных редлексов клиники детских болезней Ленинградского медицинского института под руководством профр. Н.И. Красногорского; в начале 1930-х гг. - в Институте психоневрологии Коммунистической академии. Он ученый-нейрофизиолог, автор ряда научных статей и монографии «Условные реолексы ребенка» (Москва-Ленинград, 1928) [4].

В процессе собственных исследований «в области теоретической фризиологии, при искании путей преодоления ограниченности метода условных рефрлексов Павлова», Ющенко и Чернавкин создали первую в мире радиотелеметрическую систему для фиксации параметров жизнедеятельности живых организмов в условиях произвольной активности. Авторы назвали свое изобретение «радиометодика» $[5,6]$.

Разумеется, вначале «радиометодика» была проверена и использована в экспериментах на лабораторных животных. Однако вопреки мнению ряда авторов, изобретатели прежде всего стремились к телеметрии человека. В доказательство приводим прямую цитату: «Сконструировав легкий радиопередатчик, укрепляемый на человеке, и сочетав его с рядом специальных приборов, мы получили возможность регистрировать как движения человека и животных, так и другие моменты в деятельности человеческого организма - дыхание, биение сердца и т.д. Человек при этом может свободно передвигаться, работать (что очень важно при изучении трудовых процессов)... Основные элементы нашей методики: 1) передатчик, 2) приемник и 3) различные приборы, включаемые в цепь передатчика и регистрирующие число шагов, деятельность сердца, слюноотделение и т.д. » [5, 6].

Таким образом, была впервые описана классическая структура биорадиотелеметрической системы: прибор пациента (набор датчиков и передающее радиоустройство), прибор исследователя (радиоприемник, средство фриксации и отображения принимаемых данных).

А.А. Ющенко и Л.А. Чернавкин сконструировали передающее и приемное радиоустройства. Антенна оригинального передатчика крепилась на голове обследуемого человека, а у лабораторного животного помещалась на спине. Примечательно, что общий вес передающего радиоустройства, по сообщению самих авторов, составлял всего 0,4кг. Приемным прибором служил супергетеродинный радиоприемник, запись результатов велась через специальное реле на кимографре.

Авторы пишут: «Включая в цепь передатчика ... различные приборы, мы можем регистрировать у человека число шагов, сердечную деятельность, дыхание и т.д., в опытах с собаками - специально нас интересующее слюноотделение. Для записи шагов мы прибегали к шагомеру... Тоны сердца передаем ленточным микрофоном. Угольный не годится, так как дает дополнительные шумы при движении» $[5,6]$.

Примечательно, что для радиотелеметрии процесса слюноотделения у лабораторных животных был сконструирован специальный оригинальный прибор (капающая слюна через специальную мембрану замыкала электрическую сеть, что приводило к генерации короткого радиосигнала) $[5,6]$.

К сожалению, А.А. Ющенко и Л.А. Чернавкин крайне осторожно подходили к публикации своего изобретения. Это обусловлено тем, что созданием «радиометодики» они вступали в научную дискуссию (хотя правильнее будет сказать в коноронтацию) с таким непререкаемым научным авторитетом как сам академик Иван Петрович Павлов. За два года исследований вышли в свет всего 2 статьи с детальным описанием технических аспектов метода: «Методика в настоящее время значительно видоизменяется и реконструируется, почему подробное описание ее преждевременно». После указанных публикаций в 1932 году авторы начали применять «радиометодику» как инструмент для изучения условных и безусловных рефлексов. Они видели значительные перспективы своего инженерного решения: «... [радиометодика] может быть полезной не только в различных областях фризиологии, но и в психологии, медицине, психофизиологии труда». Далее: «Возможность использовать нашу методику вне узкой области условных редлексов, в частности, в патофизиологии труда, дает нам особое удовлетворение в свете выполнения задачи изжития отставания теории от практики...» $[5,6]$.

Внезапная трагическая гибель Александра Александровича Ющенко в 1934 г. оборвала развитие динамической биотелеметрии в довоенный период... 
С конца 1940-х гг. во многих странах мира возобновились исследования в сфере динамической биорадиотелеметрии - медицинской науке нужны были новые технологии и методологии изучения организма в условиях активной деятельности. За 20 десятилетий в СССР, США, Болгарии, Венгрии, Великобритании, Германии (ГДР и ФРГ), Норвегии, Польше, Франции, Чехословакии, Японии и т.д. были сконструированы многочисленные приборы для дистанционной фиксации по радио фризиологических параметров у свободно передвигающегося человека или животного. Этой теме посвящены десятки статей. Методологические аспекты представлены в статьях R.T. Allen, C.S. Parker, T. Pessar (медицина труда), L. Rubenstein, W.E. Tolles (нормальная фризиология). Технологии телеметрических устройств публиковали В.А. Кашин, В.С. Келлер, Ю.Р. Мединец, Э.И. Римских, Л.П. Шуватов, А.F. Ах, W. Barry, D.L. Bell, G.H. Byford, S. Degre, T. Girson, J.S. McPetrie, J. Morgenstern, W.A. Shafer, A. Stattelman. Телеметрию в клинических условиях, в т.ч. при проведении фрункциональных проб, применяли D.A. Davis, K. Kitamura, T. Kobayashi, C.J. Roach, E.L. Rothfeld, L.E. Slater. Способы применения динамической биорадиотелеметрии на амбулаторном этапе лечения (фрактически, прообраз современного телемониторинга) изучали G.E. Bergey, F.W. Fascenelli, C.S. Parker. Отдельное направление «радиоредрлексометрии» (прямое продолжение работ Ющенко и Чернавкина) сорормировали О.Я. Боксер, М.И. Клевцов, П.Н. Карпенко, П.И. Румянцев, Ф.К. Герцен, В.П. Шитов, Э.Б. Элькин [4, 7-10]. Приведенные списки далеко не полные.

Вместе с тем, большинство работ носили дискретный характер. Чаще всего это были сугубо технические публикации с описанием оригинального инженерного решения без информации о его дальнейшем применении, либо - результаты испытаний конкретного прибора на ограниченной выборке.

В глобальной перспективе огромное значение в становлении динамической биорадиотелеметрии сыграл профрессор Владимир Викторович Розенблат, организовавший и возглавивший так называемую «Свердловскую биотелеметрическую группу» $[3,4,11]$.

В.В. Розенблат родился 9 декабря 1927 года. В 1950 г. он окончил Свердловский медицинский институт, всего через 3 года защитил кандидатскую диссертацию. С 1953 по 1960 гг. работал в Свердловском городском врачебно-фризкультурном дис- пансере, пройдя путь от практического врача до заведующего лабораторией медицинской радиоэлектроники. В 1960 г. В.В. Розенблат возглавил лабораторию функциональной диагностики Свердловского научно-исследовательского института гигиены труда и профзаболеваний. В 1966 г., после защиты докторской диссертации стал профрессором фризиологии труда на экономическом фракультете Уральского государственного университета. В.В. Розенблат - выдающийся ученый-фризиолог, инициатор создания врачебно-фризкультурной службы на Урале, автор более 400 научных работ (в том числе, 3 монографии, 4 учебника, 4 изобретения), под его руководством успешно защищены порядка 37 диссертаций. С детства Владимир Викторович страдал врожденным процессом атрофии зрительных нервов обоих глаз. В начале 1960-х гг. он практически полностью ослеп, однако это не стало преградой - в это десятилетие наблюдается пик его научной активности. В 1996 г. В.В. Розенблат стал академиком Российской Академии медикотехнических наук. Владимир Викторович ушел из жизни 30 апреля 2000 года. В глобальной перспективе профрессор Розенблат стал основоположником динамической биорадиотелеметрии - им создана единая методология и универсальные принципы построения приборов, использованные множеством ученых по всему миру.

Необходим подчеркнуть, что первые опыты с биотелеметрией в г. Свердловске (ныне - Екатеринбург) проводил профрессор Василий Иванович Патрушев (25.12.1910-22.04.1962 гг.) еще в 1948 г. Будучи директором Уральского фрилиала Академии наук он руководил разработкой прибора для дистанционной фриксации электрокардиограммы (ЭКГ). Непосредственным конструированием занимался инженер Лев Сигизмундович Домбровский. По политическим мотивам Патрушев был уволен, работа остановилась.

Благодаря встрече Домбровского с Розенблатом исследования возобновились в 1955 г.

Первым достижением стал ламповый радиопульсофрон весом 1,3 кг. Посредством этого прибора 29 апреля 1957 года впервые в мире была записана по радио частота сердечных сокращений спортсмена-конькобежца И.В. Зыкова. Прибор был опубликован и представлен на выставках, несколько раз использовался в исследованиях. В 1958 г. разработана новая модель радиопульсофона (использованы транзисторы, вес 0,35 кг, 
дальность действия увеличена). 20.01.1958 г. проведена успешная биотелеметрия пульса спортсменов в процессе соревнований. В 1960 г. радиопульсофон трансформирован в универсальный комбинированный прибор («КРП»), позволявший дополнительно мониторировать частоту дыхания (работа с участием Р.В. Унжина, Э.И. Римских, В.М. Форштадта и др.). «КРП» весил 0,15 кг вместе с миниатюрным аккумулятором. Радиопульсометрия стала основным методом исследования в нескольких диссертационных работах и отдельных научных проектах, выполненных представителями Свердловской биотелеметрической группы в 1960-1970-х гг. Чаще всего посредством технологий биорадиотелеметрии изучалось функционирование организма в процессе трудовой деятельности (рабочие горячих цехов, прокатчики, шахтеры). В конце 1970-х гг. «акцент сместился» - радиопульсометрия стала все больше использоваться в спорте. В результате к 1980-м гг. она стала стандартным методом врачебного контроля в спортивной медицине, широко использующимся на практике, в массе научных и методических работ [3, 4, 11].

Важно, что в 1960-е гг. сорормировалась «триада» научных задач, ставшая методологической основой научных исследований группы Розенблата:

- совершенствование технологий и методологии биорадиотелеметрии конкретного фризиологического параметра или их сочетаний в определенных условиях;

- изучение фризиологии и патофизиологии путем применения указанных технологии и методологии;

- научное развитие вопросов по экспертизе и нормированию труда.

«Триада» не только применялась «Свердловской биотелеметрической группой», но и стала основой для научного целеполагания многих исследователей по всему миру. Динамическая биорадиотелеметрия стала одним из главных методов медицины труда.

В 1960-1970-е гг. под руководством В.В. Розенблата велось несколько научных направлений биорадиотелеметрии [3, 4, 11]:

- ЭКГ (Р.В. Унжин);

- показателей внешнего дыхания (В.М. Форштадт);

- электроэнцеоралограммы (С.С. Гоорман, Я.В. Фрейдин);
(В.М. Форштадт, Б.М. Столбун, М.Л. Римских).

Постепенно приборы все более усложнялись, комбинировались, появились многоканальные телеметрические системы. Совершенствовались датчики, миниатюризировалась радиоаппаратура. Два устройства в 1963 г. были одобрены для промышленного серийного производства.

Важно отметить, что для регистрации радиотелеметрической информации был разработан специальный прибор - комплексный дешифратор (КД), позволявший не только работать с любым телеметрическим прибором группы Розенблата, но и включавший элементы автоматического анализа. А в середине 1970-х гг. реализован автоматизированный анализ радиотелеметрических данных от 5-канальной системы посредством ЭВМ. Вообще будущее биорадиотелеметрии В.В. Розенблат видел в компьютеризации [3]: ... Интерпретация огромного фактического материала, доставляемого динамической биотелеметрией, может быть плодотворной лишь при условии обработки данных с помощью счетно-решающих устройств... Программируя обработку, продумывая результаты ее и уточняя программы повторной обработки или последующих ее этапов, - только при таком подходе мы сможем обеспечить плодотворное развитие дальнейших последований и справиться с тем потоком фризиологической инорормации, который уже в настоящее время весьма велик, а в ближайшие годы станет еще большим по объему и содержанию данных при многоканальной динамической радиотелеметрии различных фрункциональных показателей в естественных условиях мышечной деятельности» [3].

Исследования велись в физиологии, медицине труда и спорта, в частности - в тяжелой атлетике (А.Т. Воробьев, М.Б. Казаков, Н.М. Ходаков, В.П. Худорожков), художественной гимнастике (Р.Н. Карелина), лечебной фризкультуре (Ф.М. Бакирова, А.П. Берсенева).

\section{Выводы}

Таким образом, за несколько лет интенсивной работы, благодаря инициативе и работе Владимира Викторовича Розенблата, была сорормирована так называемая «Свердловская биотелеметрическая группа», в которой под его руководством объединились два отряда энтузиастов: специалисты в области радиоэлетроники и 
представители медико-биологической сореры. Процитируем самого Владимира Викторовича [3]: «В 1955-1964 гг. основное внимание было направлено на методику радиотелеметрической регистрации частоты пульса и биотоков сердца; попутно мы искали подход к исследованию некоторых показателей внешнего дыхания и других функций [3]. За 9 лет разработано более 50 приборов, в том числе 16 типов передающих устройств». Отметим, что были разработаны оптимальные методики фриксации биотоков и биосигналов, сконструированы уникальные датчики и передатчики, приспособленные к различным условиям эксплуатации. В период 1957-1964 гг. исследователями Свердловской биотелеметрической группы проведено более 100 тысяч радиотелеметрических наблюдений за спортсменами в 10 видах спорта, рабочими более 50 профрессий и пациентами (в частности при фрункциональных пробах).
Впервые в мире была осуществлена динамическая биотелеметрия:

- полной кривой ЭКГ у спортсменов-конькобежцев во время соревнований;

- частота пульса у прыгунов на лыжах с трамплина при отрыве от опорного стола.

Однако основным достижением следует считать огромный массив новой информации, полученной в ходе сотен исследований в сорере нормальной и патологической фризиологии, клинической медицины. Благодаря биорадиотелеметрии сорормировалась современная спортивная медицина и аэро-космическая медицина. Методы динамической биотелеметрии группы В.В. Розенблата получили широкое распространение во всем мире.

История развития биотелеметрии в контексте космической медицины требует отдельного изучения.

\section{JUTEPATYPA}

1. Владзимирский А.В., Лебедев Г.С. Телемедицина. М.: ГЭОТАР Медиа, 2018; 576 с. [Vladzymyrskyy A.V., Lebedev G.S. Telemedicina. Moscow, GEOATR-Media, 2018; 576 s. (in Russian)].

2. Кудряшов Ю.Ю., Атьков 0.Ю. Цифровое здравоохранение: технологии персональной телемедицины для реабилитации, просилактики и активного долголетия. Инсормационные технологии и вычислительные системы 2018(4)15-22. [Kudrjashov Ju.Ju., At'kov 0.Ju. Cifrovoe zdravoohranenie: tehnologii personal'noj telemediciny dlja reabilitacii, profilaktiki i aktivnogo dolgoletija. Informacionnye tehnologii i vychislitel'nye sistemy = Information Technologies for the Physician 2018(4):15-22. (in Russian)].

3. Розенблат В.В. Радиотелеметрические исследования в спортивной медицине М.: Изд-во «Медицина», 1967;208 с. [Rozenblat V.V. Radiotelemetricheskie issledovanija v sportivnoj medicine. Moscow: «Medicina» 1967;208 p. (In Russian)]. 4. Владзимирский А.В. История телемедицины: стоя на плечах гигантов (18501979). М.: Де`Либри, 2019;410 c. [Vladzymyrskyy A.V. Istorija telemediciny: stoja na plechah gigantov (1850-1979). Moscow: De'Libri, 2019;410 s. (In Russian)]. 5. Ющенко А.А., Чернавкин Л.А. Новая радиометодика в психофизиологии труда. Социалистическая реконструкция и наука 1932(1):217-220. [Jushhenko A.A., Chernavkin L.A. Novaja radiometodika v psihofiziologii truda. Socialisticheskaja rekonstrukcija $i$ nauka = Socialist reconstruction and science 1932(1):217-220. (In Russian)].

6. Ющенко А.А., Чернавкин Л.А. Новая методика изучения безусловных и условных ресрлексов, свободно передвигающихся животных. Советская неврапотология, психиатрия и психология 1932(8):327-332. [Jushhenko A.A., Chernavkin L.A. Novaja metodika izuchenija bezuslovnyh i uslovnyh refleksov, svobodno peredvigajushhihsja zhivotnyh. Sovetskaja nevrapotologija, psihiatrija i psihologija = Soviet neuropathology, psychiatry and psychology 1932(8):327-332. (In Russian)].

7. Парин В.В., Баевский Р.М. Медицина и техника. М.: Знание, 1968;81 с. [Parin V.V., Baevskij R.M. Medicina i tehnika. Moscow, Znanie, 1968;81 s. (In Russian)]. 8. Goodman RM, Taylor WM. A statement of bio-telemetry. Biomed Sci Instrum 1964(2):213-5.

9. Hanley J. Telemetry in health care. Biomed Eng 1976 Aug;11(8):269-72. 10. Simmons WW. An introduction to biotelemetry. J Occup Med 1968 Apr;10(4):188-94.

11. Rozenblat V.V., Vorob'ev A.T. A method of picking up cardiac potentials from moving human subjects for radiotelemetry. Biull Eksp Biol Med 1962 May(52):1217-21. https://doi.org/10.1007/BF00787291.

\section{Сведения об авторах:}

Владзимирский А.В. - д.м.Н., заместитель директора по научной работе ГБУЗ «Научно-практический клинический центр диагностики и телемедицинских технологий Департамента здравоохранения Москвы»; Москва, Россия; a.vladzimirsky@npcmr.ru; РИНЦ AuthorID 820681

\section{Вклад автора:}

Владзимирский А.В. - определение актуальных научных аспектов, обзор литературы, написание текста, 100\%

Конфлликт интересов: Автор заявляет об отсутствии конфоликта интересов.

Финансирование: Исследование проведено без спонсорской поддержки.

Статья поступила: 27.03.21

Information about authors:

Vladzymyrskyy A.V. - Doctor of Medical Sciences, Deputy Director for Research, GBUZ «Scientific and Practical Clinical Center for Diagnostics and Telemedicine Technologies of the Moscow Department of Health»; Moscow, Russia; a.vladzimirsky@npcmr.ru; https://orcid.org/0000-0002-2990-7736

Author Contribution:

Vladzymyrskyy A.V. - identification of relevant scientific aspects, literature review, text writing, 100\%

Conflict of interest. The author declare no conflict of interest.

Financing. The study was performed without external funding.

Received: 27.03 .21

Accepted for publication: 29.04.21 


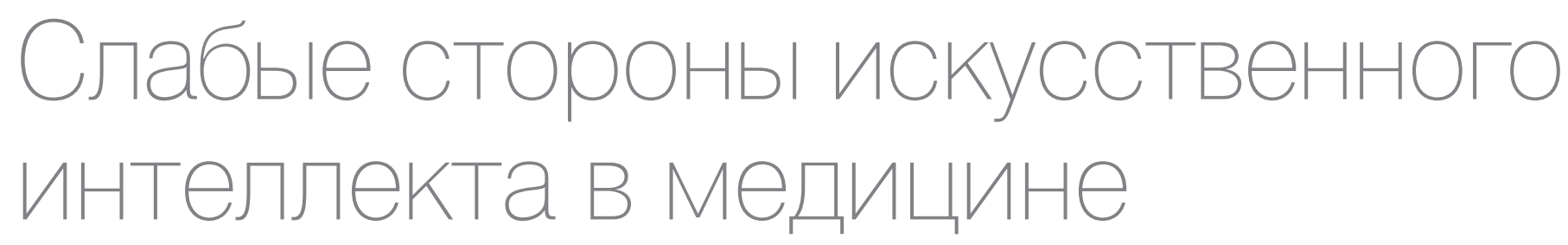

\section{И.А. Шадеркин}

Институт циоровой медицины Первого Московского государственного медицинского университета им. И.М. Сеченова (Сеченовский Университет); д. 1, стр. 2, Абрикосовский пер., стр. Москва, 119435, Россия

Контакт: Шадеркин Игорь Аркадьевич, info@uroweb.ru

\section{Аннотация:}

Ведение. В последнее время стало появляться большое количество интеллектуальных систем, которые используются в поддержке принятия врачебных решений - «искусственный интеллект в медицине».

Материал и методы. Автор публикации тоже работает над вопросами принятия врачебных решений, и, сам будучи врачом, в ходе работы и имеющейся практики обнаружил ряд важных вопросов, которыми счел необходимым поделиться с профессиональным сообществом.

Результаты. В некоторых случаях демонстрация успешной работы программного обеспечения в заявленных характеристиках (чувствительность, специфричность) происходит лишь в «надежных руках» разработчиков и на данных, которые лежат в основе программного обеспечения. При попытке продемонстрировать работу в клинических ситуациях заявленные характеристики часто не достигаются, поэтому у клинического сообщества, которое должно использовать это решение на базе ИИ, фрормируется не всегда благоприятное мнение. Автор рассматривает различные виды ошибок, способных иметь фратальный характер в принятии медицинских клинических решений - искажение первичных медицинских знаний, отсутствие знаний или недостоверные знания о предметной области, социальные искажения.

Выводы. При разработке решений на базе ИИ кажется важным учитывать вышеперечисленные моменты как разработчикам, так и пользователям.

Ключевые слова: искусственный интеллект в медицине; глубокое машинное обучение; системы поддержки принятия врачебных решений.

Для цитирования: Шадеркин И.А. Слабые стороны искусственного интеллекта в медицине. Российский журнал телемедицины и электронного здравоохранения 2021;7(2):50-52; https://doi.org/10.29188/2712-9217-2021-7-2-50-52

\section{Weaknesses of artificial intelligence in medicine}

https://doi.org/10.29188/2712-9217-2021-7-2-50-52

\section{I.A. Shaderkin}

Institute of Digital Medicine of the First Moscow State Medical University them Sechenov (Sechenov University), Abrikosovskiy per., 1, bldg. 2, Moscow, 119435, Russia

Contact: Igor A. Shaderkin, info@uroweb.ru

\section{Summary:}

Introduction. Recently, a large number of intelligent systems have begun to appear that are used to support medical decisionmaking - «artificial intelligence in medicine».

Material and methods. The author of the publication also works on the issues of making medical decisions, and, being a doctor himself, in the course of his work and existing practice, discovered a number of important issues that he considered necessary to share with the professional community.

Results. In some cases, the demonstration of the successful operation of the software in the declared characteristics (sensitivity, specificity) occurs only in the «reliable hands» of the developers and on the data that underlie the software. When attempting to demonstrate performance in clinical situations, the claimed characteristics are often not achieved, so the clinical community that must use this Al-based solution does not always form a favorable opinion. The author considers various types of errors that can be fatal in making medical clinical decisions - distortion of primary medical knowledge, lack of knowledge or inaccurate knowledge about the subject area, social distortions.

Conclusions. When developing solutions based on Al, it seems important to keep the above points in mind for both developers and users.

Key words: artificial intelligence in medicine; deep machine learning; medical decision support systems.

For citation: Shaderkin I.A. Weaknesses of artificial intelligence in medicine. Russian Journal of Telemedicine and E-Health 2021;7(2):50-52; https://doi.org/10.29188/2712-9217-2021-7-2-50-52 


\section{ВВЕДЕНИЕ}

В последнее время стало появляться большое количество интеллектуальных систем, которые используются в поддержке принятия врачебных решений - симптом-чекеры (приложения проверки симптомов заболеваний), предиктивные, аналитические системы, системы, работающие с визуальными данными (рентген-, КТ-изображения, морорология, дерматография и др.). Все эти решения в обиходе часто называют «искусственный интеллект в медицине» - тематика находится на высоте внимания государства, инвесторов и разработчиков. Эти интеллектуальные системы начинают регистрироваться как медицинские изделия, так, например, В РФ уже есть преценденты («Третье мнение», WEBIOMED).

Автор публикации тоже работает над вопросами принятия врачебных решений, и, сам будучи врачом, в ходе работы и имеющейся практики обнаружил ряд важных вопросов, которыми счел необходимым поделиться с профессиональным сообществом.

\section{КЛЮЧЕВЬIЕ MOMЕНТЬ|} РАЗРАБОТКИ ИИ

В основе решений на базе искусственного интеллекта (ИИ - «intelligence» (франц.), интеллект) лежат медицинские знания - об организме человека, этиологии, патогенезе, диагностике и методах лечения заболеваний.

Команды, создающие решения на базе ИИ, включают в себя, помимо руководства и представителей бизнеса (сэйлс, маркетинг), команду разработчиков, программистов и специалистов по знаниям, дата-сайентистов, которые, как правило, являются представителями медицинского и научного сообщества и являются экспертами в предметной области, для которой строятся решения на базе ИИ.

Разработчики используют стандартные программные библиотеки (напр. TensorFlow), которые уже разработаны международным сообществом программистов и ученых. В очень редких случаях эти библиотеки модифицируются, и разработчиками вносятся значимые изменения. Эти библиотеки используются для создания законченного бизнес-продукта.

Важным компонентом бизнес-продукта являются медицинские данные (знания), которые либо берутся из открытых источников (дата-сеты, размеченные данные), либо собираются дата-сайентистами из команды разработчиков. Созданное программное обеспечение принимает решение на основе данных/знаний, поэтому качество этих данных является ключевым аспектом правильности работы программного обеспечения.

В некоторых случаях демонстрация успешной работы программного обеспечения в заявленных характеристиках (чувствительность, специфичность) происходит лишь в «надежных руках» разработчиков и на данных, которые лежат в основе программного обеспечения. При попытке продемонстрировать работу в клинических ситуациях заявленные характеристики часто не достигаются, поэтому у клинического сообщества, которое должно использовать это решение на базе ИИ, орормируется не всегда благоприятное мнение.

\section{П ПРИЧИНЫ НЕУДАЧ В СИСТЕМЕ ПРИНЯТИЯ ВРАЧЕБНЫХ РЕШЕНИЙ}

Есть очевидные и наиболее часто упоминаемые причины некачественной работы вне заявленных характеристик ИИ в медицине:

1. Ошибки в использовании программных библиотек.

2. Некачественно собранные медицинские данные.

3. Недостаточное количество данных или выборки данных для обучения алгоритма.

4. Нерепрезентативная выборка (не все данные, не по всем клиническим случаям оказались в дата-сете).

5. Ошибки в разработке программного продукта.

Это лежащие на поверхности, часто упоминаемые причины.

Однако есть ряд других причин, которые порой не учитываются в разработке, но могут носить фратальный характер в принятии медицинских клинических решений:

1. Искажение первичных медицинских знаний.

- Приверженность эксперта дата-сайентиста к устоявшейся точке зрения в предметной области, которая продиктована личным опытом и сложившимся стереотипом клинического мышления, либо приверженностью к определенной «Школе».

- Искажение знаний, полученных в ходе клинических исследований.

- Публикации в научной литературе изначально в своем большинстве подтверждают первоначальную гипотезу исследователей.

- Данные с отрицательными результатами клинических исследований обычно не публикуются.

- Публикация отрицательного опыта 
клинической практики, врачебных ошибок, неудач лечения является сложным с этической и юридической точек зрения. Врачи редко говорят о своих ошибках на страницах высокорейтинговых научных журналов.

- «Заказной» характер клинических исследований - за многими исследованиями с «правильным дизайном» (построенном по всем правилам медицины, основанной на доказательствах) стоят заказчики - представители медицинской индустрии, которые заинтересованы в подтверждении своей первоначальной гипотезы.

- В силу бизнес-интереса проводимых исследований на них выделяется значительное финансирование, которого хватает на «правильный дизайн» исследования, создание рабочей группы, включение в исследование пациентов, аналитику и публикацию в высокорейтинговых научных журналах.

- Эти правильно построенные клинические исследования влияют на клинические рекомендации, реореренсные значения фризиологических показателей. Так, например, под влиянием подобных клинических исследований были изменены peqpeренсные показатели артериального давления (АД), сахара крови, эректильной дисфункции (МИЭФ-5).

2. Отсутствие знаний или недостоверные знания о предметной области.

- Кто занимается реальной клинической практикой, понимает, что не всегда эороективны те или иные методы диагностики, лечения, базирующиеся на клинических рекомендациях, что может говорить о недостаточном уровне знаний о состоянии организма человека, неправильной интерпретации протекающих патологических процессоров, приводящих к заболеванию и неправильном подходе к их лечению.

- Во многом врачи-практики связывают это с недостаточными знаниями и пытаются фрормировать собственные индивидуальные подходы к пове-

\section{Сведения об авторе:}

Шадеркин И.А. - к.м.н., заведующий лабораторией электронного здравоохранения Института цифровой медицины Первого Московского государственного медицинского университета им. И.М. Сеченова; Москва, Россия; info@uroweb.ru; РИНЦ Author ID 695560

\section{Вклад авторов:}

Шадеркин И.А. - дизайн исследования, написание текста, 100\%

Конфликт интересов: Автор заявляет об отсутствии конорлита интересов.

Финансирование: Исследование проведено без спонсорской поддержки

Статья поступила: 15.05.21

Принята к публикации: 01.06.21 дению в той или иной ситуации («авторские» схемы лечения, собственные клинические Школы).

- На приеме практически нет возможности сказать пациенту, что врач не знает какой ставить диагноз или как его лечить. Сложилось мнение, что пациент всегда должен выйти от врача с решением своей проблемы. С другой стороны, это дополнительно продиктовано взглядом СМИ на текущее состояние науки и здравоохранения, когда в СМИ представляются абсолютные знания и современное состояние проблем. На этом фроне очень сложно специалисту, который несет юридическую ответственность, сказать, что он не знает или не уверен в диагнозе или методах лечения.

3. Социальные искажения.

- Перспективность применения к пациенту того или иного метода, использование дорогостоящих методов диагностики и лечения, прогноз развития заболевания, эвтаназия, личное отношение врача к пациенту и другие моменты - лежат за рамками медицины, основанной на доказательствах. Принятие решения врачом в таких ситуациях носит иррациональный характер и лежит в рамках этических, культурных, а порой и религиозных аспектов. Такие знания очень сложно на сегодняшнем уровне собрать, классиоицировать и алгоритмизировать. Как правило, решения принимает врач на свой страх и риск, под свою ответственность, не афиширует, и тем более, не публикует.

В ряде клинических ситуаций принятие врачом таких решений носит ключевой характер, но не может быть протоколировано и алгоритмизировано в программном обеспечении в ИИ.

\section{вЫІводь}

При разработке решений на базе ИИ кажется важно учитывать вышеперечисленные моменты как разработчикам, так и пользователям.

\section{Information about author:}

Shaderkin I.A. - PhD, Head of the Laboratory of Electronic Health, Institute of Digital Medicine, Sechenov University; Moscow, Russia; info@uroweb.ru; https://orcid.org/0000-0001-8669-2674

Authors contributions:

Shaderkin I.A. - research design, text writing, 100\%

Conflict of interest: The author declare no conflict of interest.

Financing: The study was performed without external funding

Received: 15.05 .21

Accepted for publication: 01.06.21 


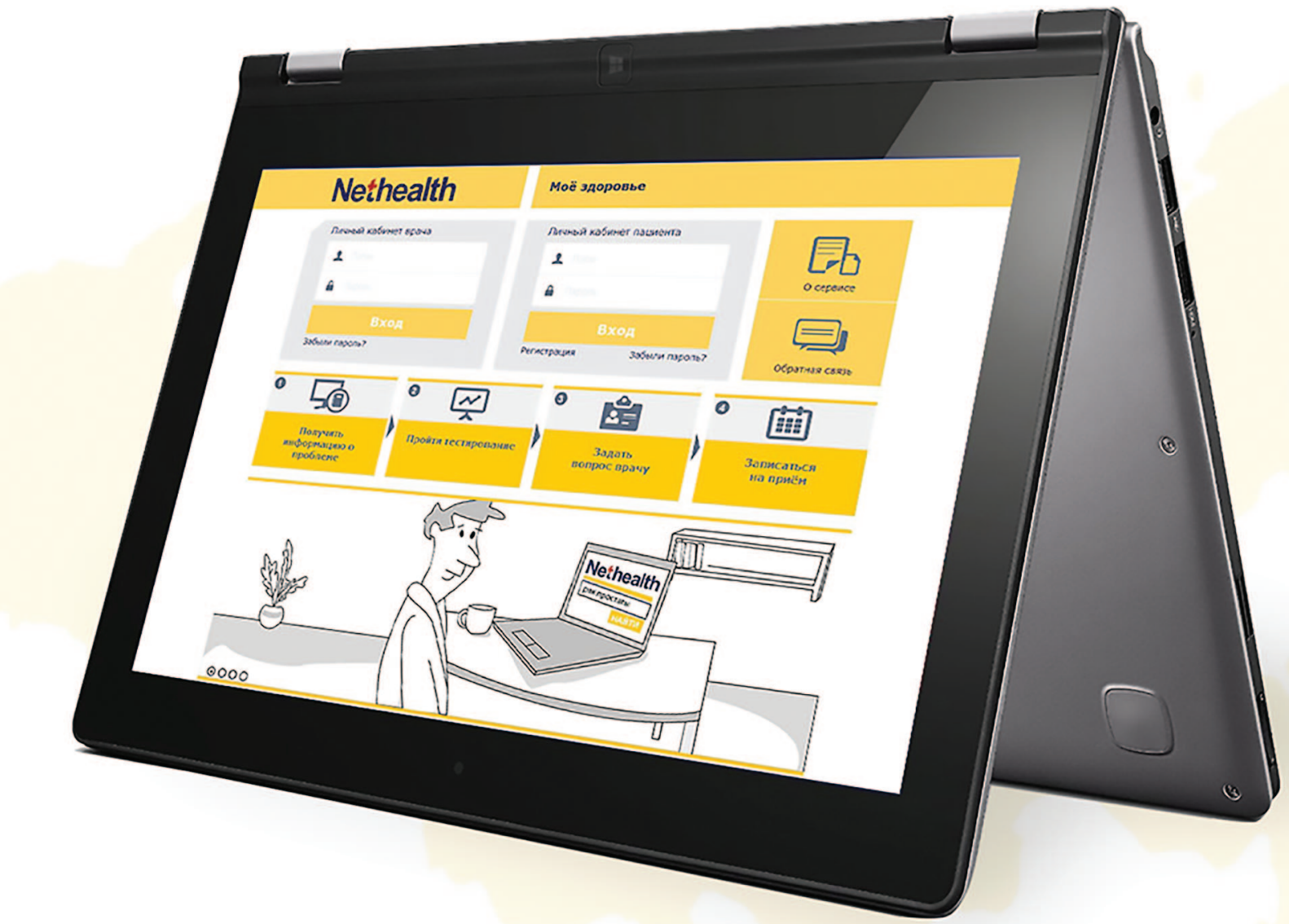

\section{Что такое сервис медицинских услуг}

0 Nethealth

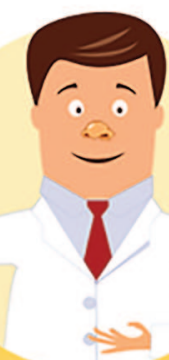

Помощь не отходя от компьютера, планшета или телефона

₹ Консультации квалифицированного врача-уролога

1 Бесплатное анкетирование на наличие тревожных симптомов ряда заболеваний

П Проект, созданный при поддержке НИИ урологии
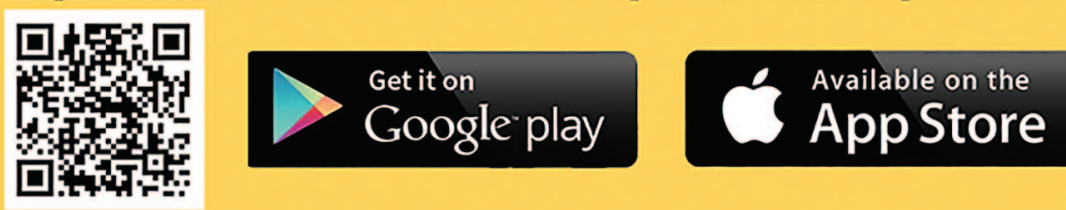

Мы в социальных сетях

(B) www.vk.com/nethealth

(f) www.facebook.com/nethealth.ru 
jtelemed.ru ИЗДАТЕЛЬСКИЙ ДОМ «УРОМЕДИА»

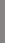

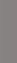

\section{.}

